Report of Investigations 2011-7

Version 1.1

\title{
TSUNAMI INUNDATION MAPS OF WHITTIER AND WESTERN PASSAGE CANAL, ALASKA
}

by

D.J. Nicolsky, E.N. Suleimani, R.A. Combellick, and R.A. Hansen

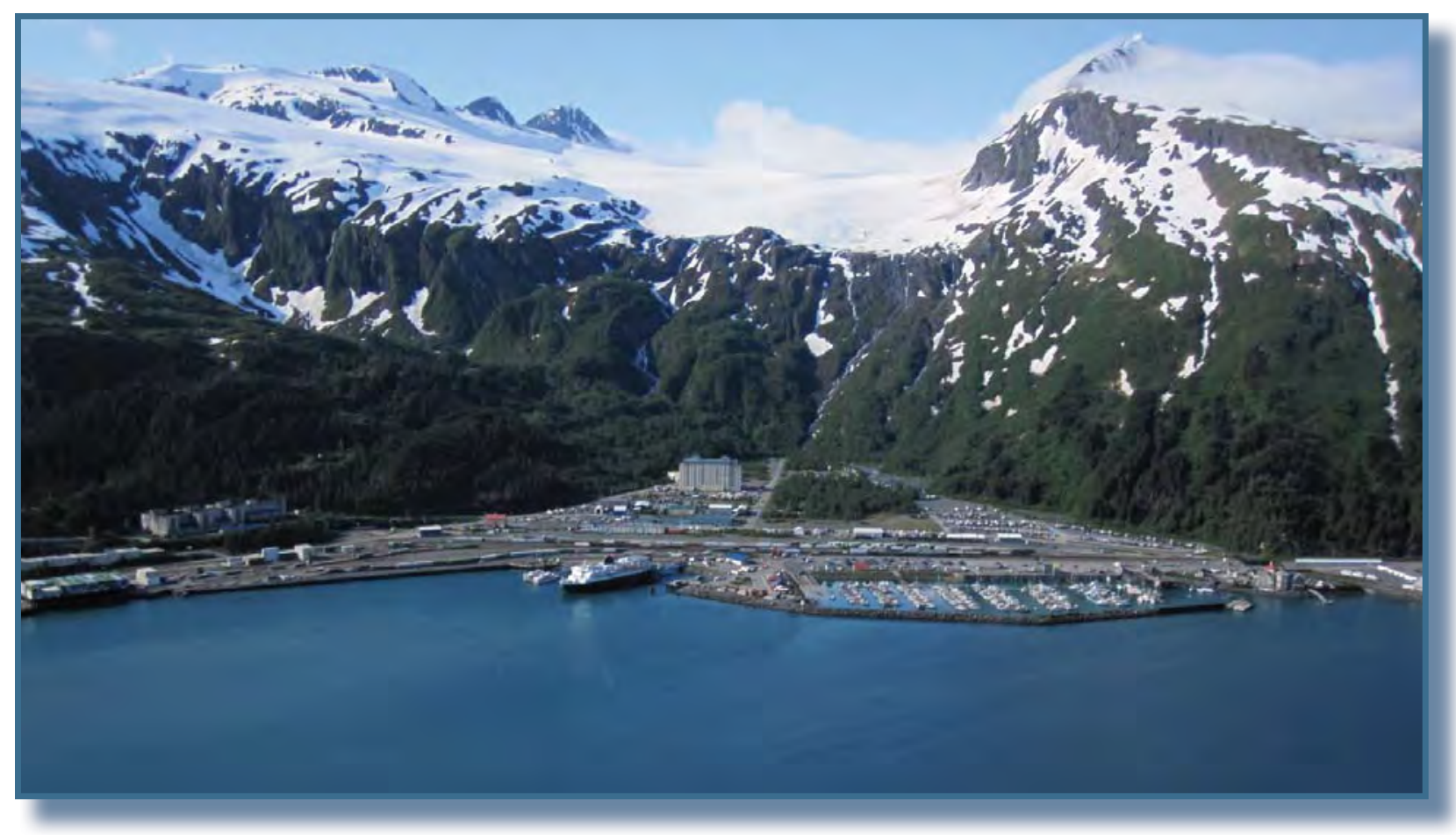

Published by

STATE OF ALASKA

DEPARTMENT OF NATURAL RESOURCES

DIVISION OF GEOLOGICAL \& GEOPHYSICAL SURVEYS

2011

$\$ 7.00$

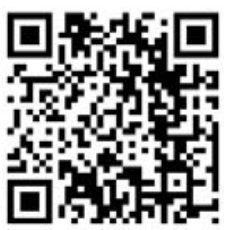





\section{Report of Investigations 2011-7}

\section{TSUNAMI INUNDATION MAPS OF WHITTIER AND WESTERN PASSAGE CANAL, ALASKA}

by

D.J. Nicolsky, E.N. Suleimani, R.A. Combellick, and R.A. Hansen

2011

This DGGS Report of Investigations is a final report of scientific research.

It has received technical review and may be cited as an agency publication.

Front photo. Aerial view of Whittier, Alaska, looking south over Passage Canal. Photo by Gabriel Wolken. 


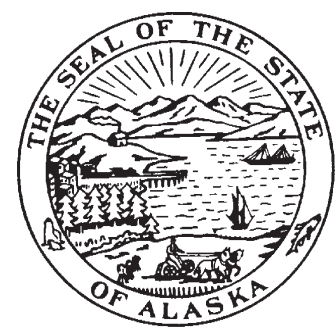

STATE OF ALASKA

Sean Parnell, Governor

DEPARTMENT OF NATURAL RESOURCES

Daniel S. Sullivan, Commissioner

\section{DIVISION OF GEOLOGICAL \& GEOPHYSICAL SURVEYS Robert F. Swenson, State Geologist and Director}

Publications produced by the Division of Geological \& Geophysical Surveys (DGGS) are available for free download from the DGGS website (www.dggs.alaska.gov). Publications on hard-copy or digital media can be examined or purchased in the Fairbanks office:

\section{Alaska Division of Geological \& Geophysical Surveys 3354 College Rd., Fairbanks, Alaska 99709-3707 \\ Phone: (907) 451-5020 Fax (907) 451-5050}

dggspubs@alaska.gov

www.dggs.alaska.gov

Alaska State Library

State Office Building, 8th Floor 333 Willoughby Avenue

Juneau, Alaska 99811-0571

Elmer E. Rasmuson Library

University of Alaska Fairbanks

Fairbanks, Alaska 99775-1005
Alaska Resource Library \& Information Services (ARLIS)

3150 C Street, Suite 100

Anchorage, Alaska 99503

University of Alaska Anchorage Library 3211 Providence Drive

Anchorage, Alaska 99508 


\section{CONTENTS}

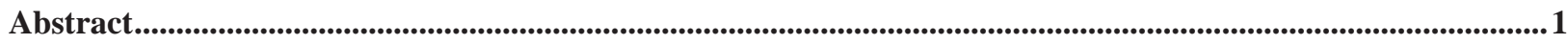

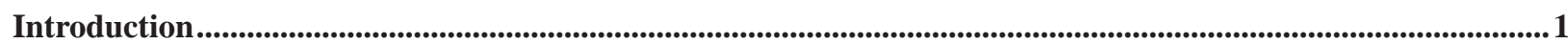

Project background: Regional and historical context ..........................................................................................................

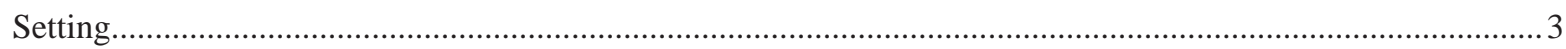

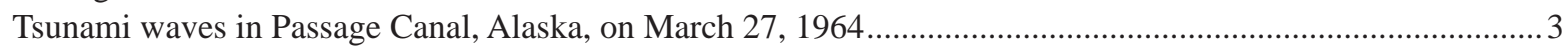

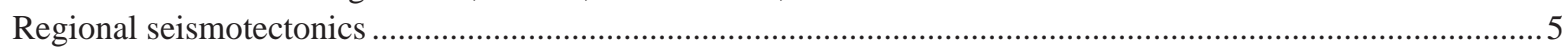

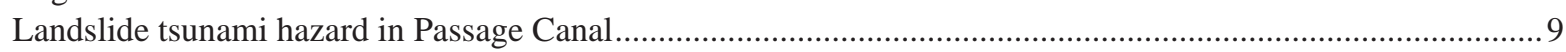

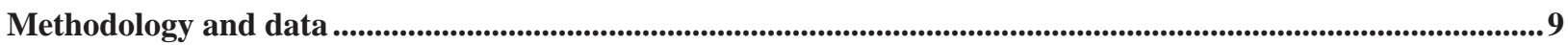

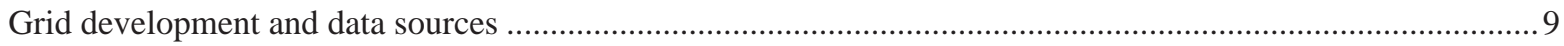

Numerical model of tsunami wave propagation and runup ............................................................................... 13

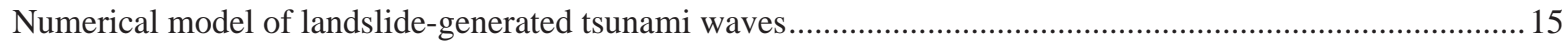

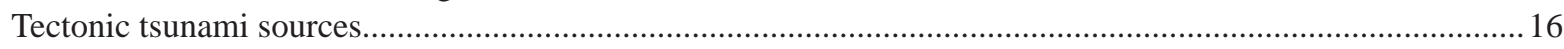

Models of the 1964 Great Alaska Earthquake ........................................................................................... 16

Scenario 1. Repeat of the 1964 event: Source function based on coseismic deformation model

by Johnson and others (1996) (JDM) ......................................................................... 17

Scenario 2. Repeat of the 1964 event: Source function based on coseismic deformation model by Suito and Freymueller (2009) (SDM) ....................................................................... 17

Models of the multi-segment Great Alaska Earthquake ..............................................................................17

Scenario 3. Multi-Segment JDM event: Source function based on extension of the JDM.....................17

Scenario 4. Multi-Segment SDM event: Source function based on extension of the SDM ....................17

Model of the Cascadia Subduction Zone Earthquake ..................................................................................17

Scenario 5. Rupture of the Cascadia zone, including portions of the margin along the British Columbia and northern California shores.........................................................................19

Source Models of Hypothetical Tsunamigenic Earthquakes......................................................................... 19

Scenario 6. Modified 1964 event: Prince William Sound asperity of the Johnson deformation

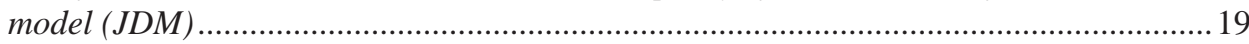

Scenario 7. Modified 1964 event: Kodiak asperity of the JDM..........................................................2 20

Scenario 8. Modified 1964 event: Prince William Sound asperity of the Suito deformation model

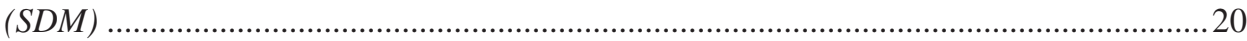

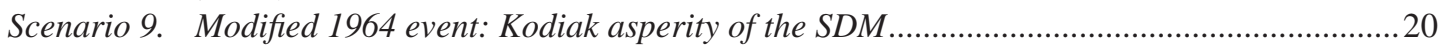

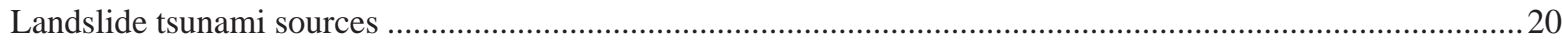

Multiple submarine slope failures in Passage Canal during the 1964 earthquake.......................................20

Scenario 10. Repeat of the 1964 event: Major underwater slide complexes of the 1964 earthquake-

Harbor, Airport, and Glacier (HAG) landslides...............................................................2 20

Hypothetical landslide tsunami sources ..................................................................................................... 24

Scenario 11. Hypothetical event: Major underwater slide complex offshore of the northern shore of Passage Canal .................................................................................................................. 24

Scenario 12. Hypothetical event: Major underwater slide complex offshore of the Billings Creek delta ...................................................................................................................... 24

Scenario 13. Hypothetical event: Simultaneous failure of underwater slide complexes described by

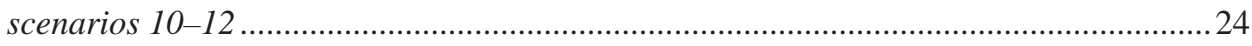

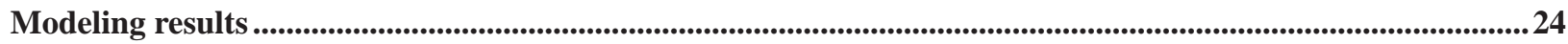

Numerical modeling of the 1964 tsunami in Passage Canal: Model verification ................................................24

Results of hypothetical tsunami scenarios ............................................................................................... 30

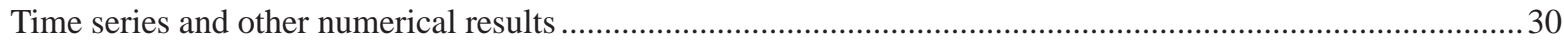

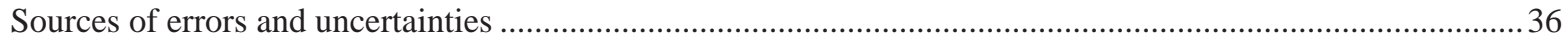


Summary

Acknowledgments .................................................................................................................................................................... 36

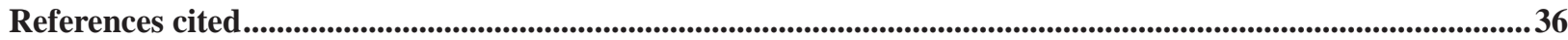

Appendix A. Time-series diagrams of water levels and velocities at selected locations .....................................41

Appendix B. Potential rockfall-generated tsunami at Whittier, Alaska .........................................................57

\section{TABLES}

Table 1. Nested grids used to compute propagation of tsunami waves generated in the Gulf of Alaska to the city of Whittier

2. Fault parameters for the Yakataga-Yakutat (YY) segment......................................................................17

\section{FIGURES}

Figure 1. Map of south-central Alaska, identifying major faults and the rupture zone of the 1964 Great Alaska

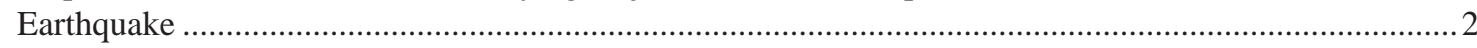

2. Schematic view of the pre-earthquake city infrastructure and the extent of the 1964 tsunami, and an

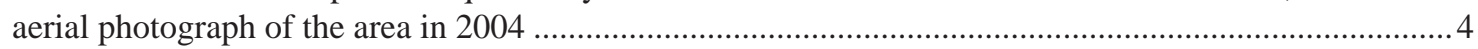

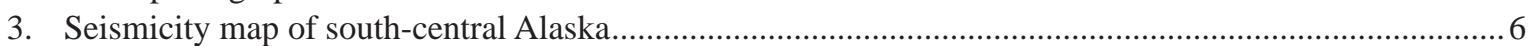

4. Map of south-central Alaska with the rupture zone of the 1964 Great Alaska Earthquake and divisions

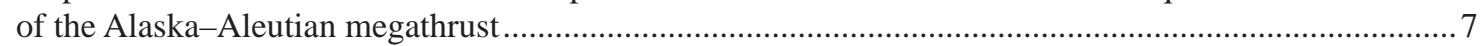

5. Map showing the geologic setting of the Yakutat block with major faults.................................................. 8

6. Telescoping embedded bathymetry/topography grids for numerical modeling of tsunami propagation

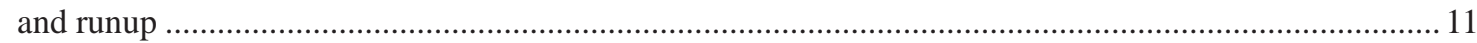

7. Map showing locations of real time kinematic GPS measurements in downtown Whittier and airport

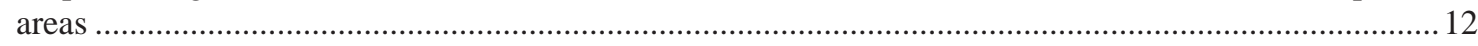

8. Graphs showing measurement of sea level and predicted water level dynamics in Whittier....................13

9. Graph showing original and corrected digital elevation models (DEMs) of the Whittier downtown

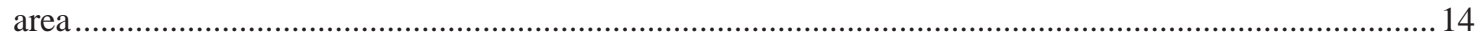

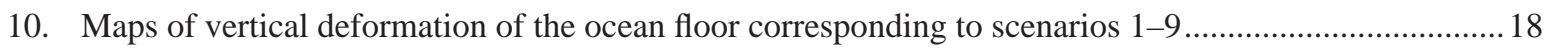

11. Map of Whittier showing pre- and post-earthquake bathymetry, wave height and direction, and

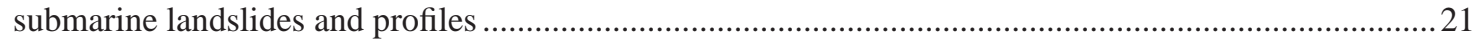

12. Pre- and post-earthquake bathymetry profiles along cross-sections A-A', B-B', and C-C', shown in

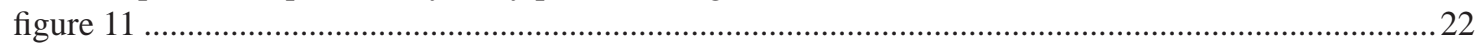

13. Digitally edited digital elevation model (DEM) showing elevation in meters above the pre-earthquake mean lower low water (MLLW) level............................................................................23

14. Illustrations showing initial thickness of landslides at Harbor-Airport-Glacier (HAG) landslide complex, and locations and thicknesses of the north shore and Billings Creek landslides ........................22

15. Schematic drawings of the city harbor before the earthquake, after the earthquake and during the

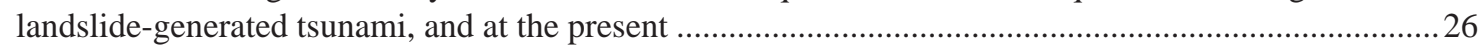

16. Maps showing maximum computed runup caused by landslide-generated tsunami waves in Passage

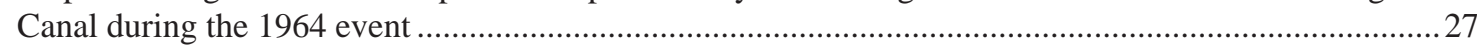

17. Graph of modeled water level dynamics of landslide-generated waves at certain locations near the

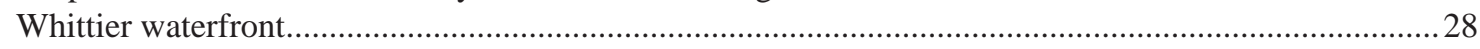

18. Graph of modeled water level dynamics at point 20 in the Whittier harbor during the 1964 tectonic

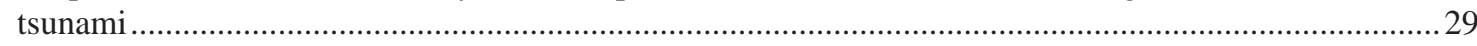

19. Map showing observed and modeled 1964 inundation caused by tectonic and landslide-generated waves. 
20. Computed water level dynamics and inundation areas in the Whittier harbor, according to scenarios

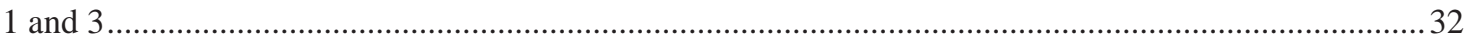

21. Map showing maximum computed potential runup by landslide-generated tsunami waves in Passage

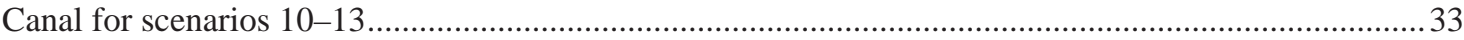

22. Map showing modeled potential inundation by tectonic and landslide-generated waves for selected scenarios.

23. Map showing maximum composite potential inundation from tectonic and landslide-generated waves for all scenarios shown in figure 21, and maximum composite flow depths over dry land.......................25 



\title{
Tsunami inundation maps of Whittier and western Passage Canal, Alaska
}

\author{
by \\ D.J. Nicolsky ${ }^{1}$, E.N. Suleimani ${ }^{1}$, R.A. Combellick², and R.A. Hansen ${ }^{1}$
}

\begin{abstract}
The purpose of this study is to evaluate potential tsunami hazards for the community of Whittier and western Passage Canal area. We numerically model the extent of inundation due to tsunami waves generated from earthquake and landslide sources. Tsunami scenarios include a repeat of the tsunami triggered by the 1964 Great Alaska Earthquake, as well as tsunami waves generated by a hypothetically extended 1964 rupture, a hypothetical Cascadia megathrust earthquake, hypothetical earthquakes in Prince William Sound, and Kodiak asperities of the 1964 rupture. Local underwater landslide events in Passage Canal are also considered as credible tsunamigenic scenarios. Results of numerical modeling combined with historical observations in the region are intended to provide guidance to local emergency management agencies in tsunami hazard assessment, evacuation planning, and public education for reducing future tsunami damage.
\end{abstract}

\section{INTRODUCTION}

Subduction of the Pacific plate under the North American plate resulted in numerous great earthquakes and still has the greatest potential to generate tsunamis in Alaska. The Aleutian megathrust (shown in fig. 1), where the Pacific plate is being subducted, is the most seismically active tsunamigenic fault zone in the U.S. Several historic tsunamis that were generated by earthquakes on the Alaska-Aleutian subduction zone have resulted in widespread damage and loss of life after traveling across the Pacific for hours and impacting exposed locations around the ocean. However, tsunamis originating in the vicinity of the Alaska Peninsula, Aleutian Islands, and Gulf of Alaska are considered to be a near-field hazard for Alaska, and can reach Alaska's coastal communities within minutes of the earthquake. Saving lives and property depends on how well a community is prepared, which makes it essential to estimate the potential flooding of the coastal zone in the event of a local or distant tsunami.

On March 27, 1964, the Prince William Sound area of Alaska was struck by the largest earthquake ever recorded in North America. This $\mathrm{M}_{\mathrm{w}} 9.2$ megathrust earthquake generated the most destructive tsunami in Alaska history and, farther south, impacted the west coast of the United States and Canada. In addition to the major tectonic tsunami generated by an ocean floor displacement between the trench and coastline, more than 20 local tsunamis were generated by landslides in coastal Alaska. They arrived almost immediately after shaking was felt, leaving no time for warning or evacuation. Of the 131 fatalities associated with this earthquake, 122 were caused by tsunami waves (Lander, 1996). Local tsunamis caused most of the damage and accounted for 76 percent of tsunami fatalities in Alaska. The city of Whittier (shown in fig. 2), in Passage Canal, greatly suffered from local landslide-generated waves. Although a tectonic tsunami was not noticed by local residents and its effect on the port infrastructure remains unknown, the town sustained great damage and 13 people perished in the tsunamis. Because local landslide-generated tsunamis were responsible for most of the damage in Whittier during the 1964 earthquake, the potential occurrence of similar events must be evaluated for comprehensive inundation mapping and for development of tsunami evacuation maps.

The production of tsunami evacuation maps for a community consists of several stages. First, we develop hypothetical tsunami scenarios on the basis of credible potential tsunamigenic earthquakes and submarine landslides. Then we perform model simulations for each of these scenarios. The results are compared with any historical tsunami observations, if such data exist. Finally, we develop a "worst case" inundation line that encompasses the maximum extent of flooding based on model simulation of all source scenarios and historical observations. The "worst case" inundation line becomes a basis for local tsunami hazard planning and development of evacuation maps.

The tsunami inundation maps of Whittier and Passage Canal described in this report represent the results

${ }^{1}$ Alaska Earthquake Information Center, Geophysical Institute, University of Alaska, P.O. Box 757320, Fairbanks, Alaska 99775-7320

${ }^{2}$ Alaska Division of Geological \& Geophysical Surveys, 3354 College Rd., Fairbanks, Alaska 99709-3707 


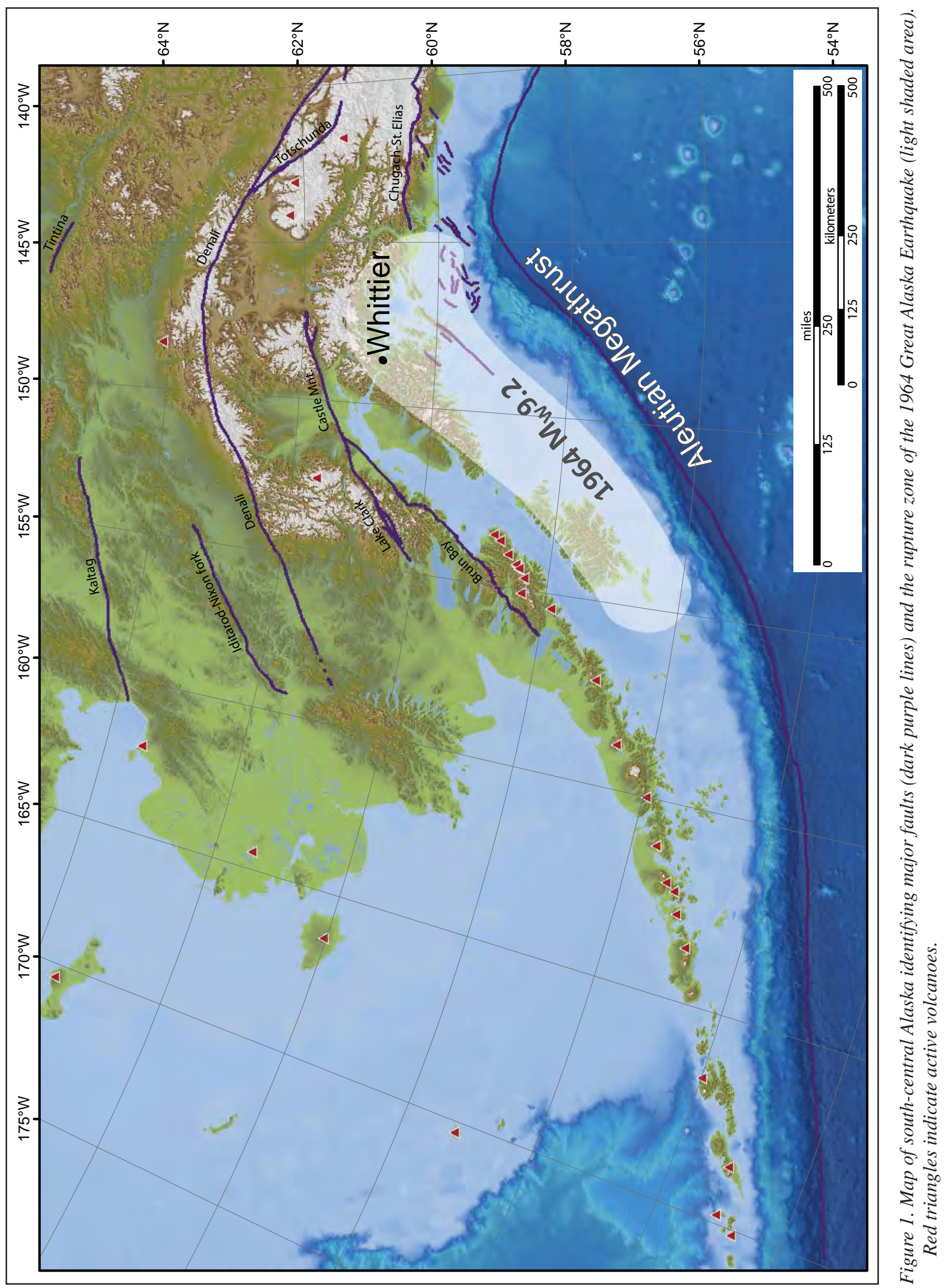


of the continued collaboration between agencies ${ }^{3}$ to produce inundation maps for many Alaskan coastal communities. In this report, we generally provide both metric and imperial units of measure. If it is necessary to quote some existing data, we state the data in the original and metric units of measure. Recall that one foot $(1 \mathrm{ft})$ is approximately 0.305 meters $(0.305 \mathrm{~m})$, and one mile (1 mi) is approximately 1.609 kilometers (1.609 km).

\section{PROJECT BACKGROUND: REGIONAL AND HISTORICAL CONTEXT}

\section{SETTING}

The port of Whittier is near the western end of Passage Canal, about $60 \mathrm{mi}$ southeast of Anchorage at approximately $60^{\circ} 46^{\prime} \mathrm{N}$ latitude and $148^{\circ} 41^{\prime} \mathrm{W}$ longitude. The port was built in 1942-1943 to provide an all-weather terminal for the Alaska Railroad. Since its construction in the 1940s, Whittier has been a focal point for the flow of supplies and equipment from tidewater to Anchorage and the interior of Alaska. Whittier was severely damaged by the 1964 earthquake and tsunami waves. The loss of a major port facility, coupled with destruction of those in Seward and Valdez, impeded post-earthquake supply distribution to other earthquakeaffected areas such as Anchorage and Fairbanks (Kachadoorian, 1965).

The port of Whittier has developed considerably since the 1964 earthquake; its economy is more diversified and includes tourism, commercial fishing, and fish processing. Whittier hosts around 45 cruise ship dockings per year, is a port for the state ferry system (Alaska Division of Community Advocacy, 2005), and its availability as an all-weather port makes it an important supply center for interior Alaska. Much of the state's economic activity and infrastructure are still located on or near the coast, ports, and harbors-areas inundated in 1964. Figure 2a shows the pre-earthquake city infrastructure and a blue line that marks the observed inundation limit after the 1964 tsunami. Docks, railroad, and tourism activities are currently located within the previous inundation area, as shown in figure 2b. Many of these facilities have been constructed or relocated since 1964, and the configuration of the shoreline has changed significantly.

The retreat of glaciers that carved Passage Canal left a steep-walled, U-shaped fjord (bathymetry contours of the canal are presented later in the report). The main harbor and port facilities are built mostly on the southern shore of Passage Canal on a fan-shaped delta formed by Whittier Creek. The delta is approximately $3.2 \mathrm{~km}$ (2 mi) wide, $2.4 \mathrm{~km}$ (1.5 mi) long, and is formed by unconsolidated deposits of outwash and stream gravel (Kachadoorian, 1965). The creek delta slopes fairly uniformly from sea level to approximately $27.5 \mathrm{~m}$ (90 ft) in elevation. The head of Passage Canal is a low-lying deltaic area with a width of about $3.7 \mathrm{~km}$ (2.3 mi) and length $3.7 \mathrm{~km}$ (2.3 $\mathrm{mi})$; the seaward slope is approximately $26 \mathrm{~m} / \mathrm{km}(140 \mathrm{ft} / \mathrm{mi})$. In the southern part of this lowland, several creeks flow into the ocean from Portage Pass, Shakespeare Glacier, and Learnard Glacier. When Learnard Glacier retreated, it left a moraine with irregular, hummocky topography at the northern part of the lowland.

\section{TSUNAMI WAVES IN PASSAGE CANAL, ALASKA, ON MARCH 27, 1964}

The following account of the tsunami waves at Whittier is taken from Kachadoorian (1965) unless otherwise noted. The M 9.2 Alaska earthquake of March 27, 1964, at Whittier was characterized by strong ground motion generally in an east-west direction, although some residents stated that the motion was in a north-northwest-south-southeast direction. The seismic motion accelerated to its maximum intensity in about one-half minute, maintained its strength for one and one-half minutes, and then gradually subsided. Eyewitnesses who were on the bedrock reported that the motion was of a jarring type, while the ones located on unconsolidated sediments described the motion as a rolling or "roundand-round" type. The post-earthquake studies by the U.S. Geological Survey (USGS) determined that the land subsided in Whittier by $1.6 \mathrm{~m}$ (5.3 ft), and the land shifted laterally by about $8.2 \mathrm{~m}(27 \mathrm{ft})$, almost transverse to Passage Canal, in a southeast direction (Wilson and Tørum, 1972).

Whittier, unlike many coastal communities damaged by the 1964 earthquake, had a limited record of tsunami waves on marigrams. The sequence of waves in Passage Canal was reconstructed from observations provided by eyewitnesses. We note that for these reasons there are inherent uncertainties in estimates of wave time arrivals and wave heights.

At least three waves were observed during the earthquake or immediately after it (Kachadoorian, 1965). A minute after the shaking began, a glassy wave, containing no debris, apparently no suspended sediment, and traces of turbulence, rose to the altitude ${ }^{4}$ of $7.6 \mathrm{~m}(25 \mathrm{ft})$

\footnotetext{
${ }^{3}$ To help mitigate the hazard that earthquakes and tsunamis pose to Alaska coastal communities, the Alaska Tsunami Mapping Team (ATMT) was created. It consists of personnel from the Geophysical Institute at the University of Alaska Fairbanks and from the State of Alaska Division of Geological \& Geophysical Surveys. The ATMT participates in the National Tsunami Hazard Mitigation Program by evaluating and mapping potential inundation of selected parts of the Alaska coastline using numerical tsunami modeling. ${ }^{4}$ Unless otherwise noted, altitudes are based on a pre-earthquake datum and do not reflect the $1.6 \mathrm{~m}(5.3 \mathrm{ft})$ regional subsidence of the Whittier area during the earthquake. Datum for subaerial contours is mean sea level (MSL). For example, a $12.2 \mathrm{~m}$ (40 ft) wave has an

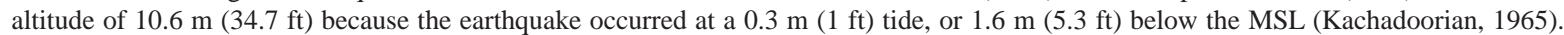




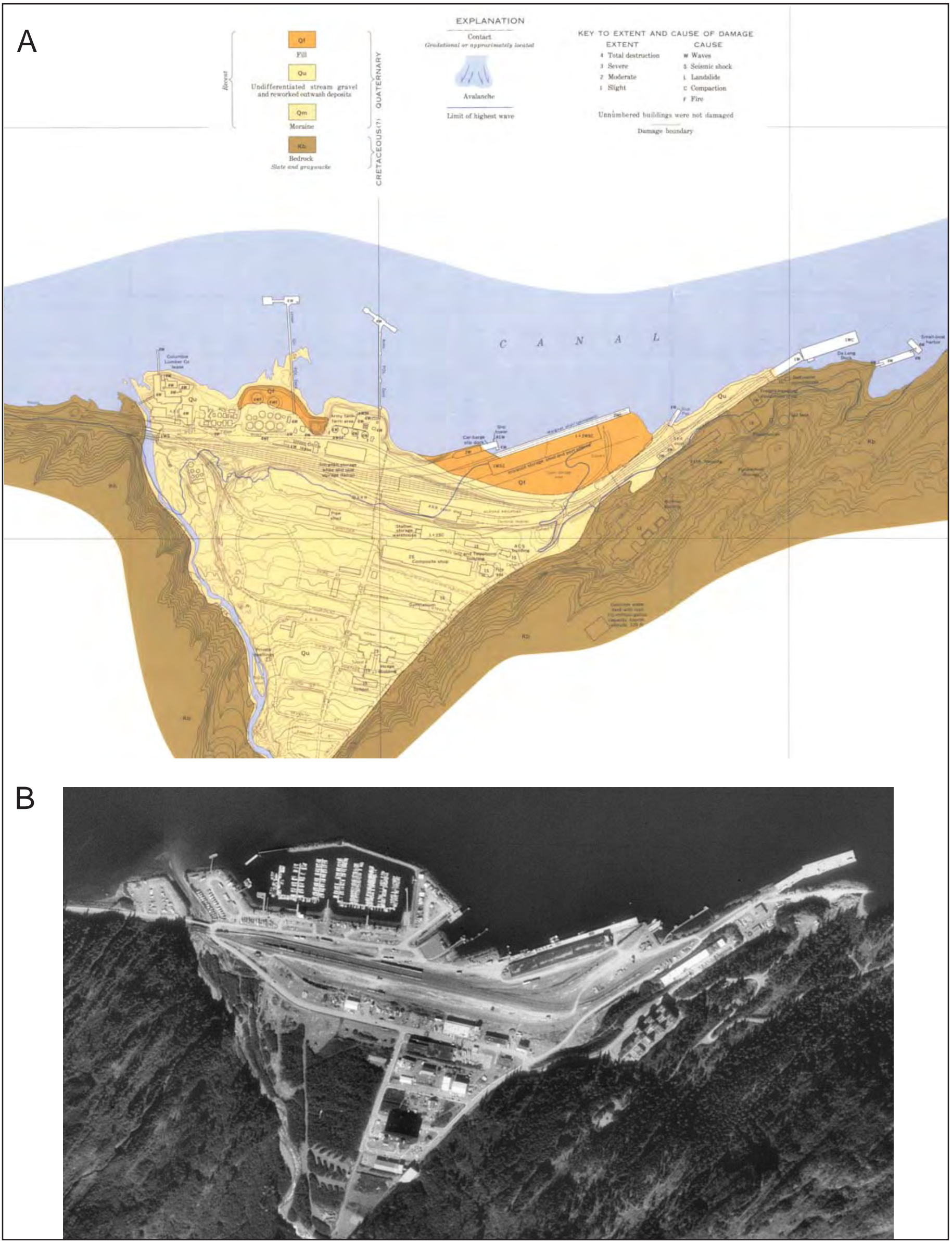

Figure 2. (A) Schematic view of the pre-earthquake city infrastructure and the extent of the 1964 tsunami (adopted from Kachadoorian, 1965, plate 1). The blue line indicates the observed extent of the tsunami inundation. (B) The 2004 aerial photography of Whittier reveals that most of the tourist attractions are within the 1964 inundation zone. 
above sea level, which at that time was $0.3 \mathrm{~m}(1 \mathrm{ft})$ above the mean lower low water (MLLW) level. The wave rose rapidly and immediately receded. Then, a minute to a minute and one-half later, a muddy 12.2-m (40-ft)-high breaking wave inundated the port facilities and ran up to an elevation of $10.7 \mathrm{~m}$ (35 ft), approximately $2.7 \mathrm{~m}(9 \mathrm{ft})$ above the ground level at the Alaska Railroad depot. The third wave hit the town approximately 45 seconds after the second one, and was a breaking wave and similar in nature to the second wave, except its amplitude was smaller, reaching an elevation of $9.2 \mathrm{~m}$ (30 ft) near the depot. There are no eyewitnesses to waves that struck the shore at other locations along Passage Canal. However, the inundation line was clearly evident from scattered debris and marks on fresh snow. The most elevated location that was inundated by waves was $31.7 \mathrm{~m}$ (104 ft) above mean sea level (MSL), along the northern shore of Passage Canal. Near the airstrip, the wave topped $6.1 \mathrm{~m}$ (20 ft) altitude, while one-quarter mile north the inundation line was at $25 \mathrm{~m}$ (82 ft) elevation. In Whittier, the maximum altitude reached by the wave was $13.1 \mathrm{~m}$ (43 ft) at the small boat harbor northeast of the Alaska Railroad depot. On the waterfront area waves reached the altitude of $7.9 \mathrm{~m}$ (26 ft).

Unlike residents of Valdez and Cordova, who observed high waves late in the evening, Whittier residents noticed no 'strange' waves in Passage Canal other than the three that struck during and immediately after the earthquake. The tectonic tsunami, which should have arrived in Whittier no later than one hour after the earthquake, was probably not observed and its damage to the port of Whittier remains unknown. There are several plausible explanations for water dynamics in Passage Canal during the shaking and immediately after it. Kachadoorian (1965) argued that the observed 'glassy hump’ of water was caused by a submarine landslide. However, the presented explanation of the secondary wave-that it was generated when a landslide came to rest in the middle of Passage Canal-is arguable because of the assumed vertical water velocity. Later, Wilson and Tørum (1968) considered a resonant trinodal seiche, caused by an inertial effect of the water as Passage Canal was suddenly pushed against it. Although this hypothesis is plausible, the lateral land motion requires specific dynamics that match certain resonance periods. Although it is difficult to qualify the first observed wave, there is a general agreement that the second and third waves were landslide-generated. The landslides occurred in delta sediments at the head of Passage Canal, in delta sediments and fill at the Whittier waterfront, and possibly in a submarine lateral moraine along the northern shore of Passage Canal. It is highly probable that these landslides did not occur simultaneously, but rather at two or three different times during the earthquake.
At the time of the earthquake only 70 people were living in Whittier, and 13 of them perished during the tsunami. Waves completely destroyed the small boat harbor, stub pier, car-barge slip dock, U.S. Army storage tanks, a lumber camp (12 of the 13 dead were in the lumber camp), and damaged the FAA station, airstrip, highway, and railroad bridges spanning Whittier Creek. According to Kachadoorian (1965), the total damage to the federal and private enterprises in Whittier was in excess of \$5 million in 1964 dollars $^{5}$. Higher estimates of damage were derived by Tudor (1964), who estimated that the tsunamis at Whittier were responsible for about \$10 million. Relative to its population, Whittier must be considered to have sustained the heaviest damage among all Alaska communities that were affected by the 1964 earthquake.

\section{REGIONAL SEISMOTECTONICS}

Passage Canal is on the northeastern shore of the Kenai Peninsula, near a plate boundary where the Pacific and North American plates converge along the Aleutian Megathrust (DeMets and others, 1990; Page and others, 1991). Whittier is in the northeast section of the Aleutian Megathrust, where the megathrust is strongly coupled and has a shallow dip angle of about 7 degrees. This area has produced some of the largest earthquakes in the world, such as the $\mathrm{M}_{\mathrm{w}} 9.2$ Great Alaska Earthquake of 1964 that caused 285,000 km² area of surface deformation (Plafker, 1969).

Figure 3 shows pre- and post-1964 seismic activity in south-central Alaska with locations determined by the Alaska Earthquake Information Center (AEIC) at the University of Alaska Fairbanks. Doser and Brown (2001) find that the central and southern Kenai Peninsula has been seismically quiet at the $M_{w}>5$ level since the 1964 event, while the Prince William Sound area has continued to experience seismic activity similar to its history prior to the 1964 earthquake. The events with moment magnitude less than 5 are shown as dots and color coded according to depth. Prior to installation of the seismic network in Alaska in the early 1970s, only larger events with $M_{w} \geq 6$ could be reliably located. Since the installation of the network, events of much smaller magnitude have been regularly located.

According to the segmentation model of Nishenko and Jacob (1990), south-central Alaska includes three segments of the megathrust: the Yakataga-Yakutat (YY), Prince William Sound (PWS), and Kodiak Island (KI) segments, all shown in figure 4. Using seismic wavefront data, Christensen and Beck (1994) show that there were two areas of high moment release, representing the two major asperities of the 1964 rupture zone: the Prince Wil-

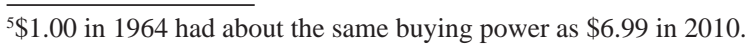


liam Sound asperity with an average slip of $18 \mathrm{~m}$ (59 ft), and the Kodiak asperity with an average slip of $10 \mathrm{~m}$ (33 ft). Analysis of historical earthquake data in PWS and KI segments (Nishenko and Jacob, 1990) showed that the KI segment produced significant megathrust earthquakes more frequently and also independently of the PWS segment. Paleoseismic data also show that the KI segment ruptured independently in a large earthquake about 500 years ago, about 360 years more recently than the penultimate great earthquake that ruptured both the KI and PWS segments (Carver and Plafker, 2008).

The results of joint inversion of tsunami and geodetic data from the 1964 earthquake (Johnson and others, 1996) also suggest the division of the rupture zone into two different segments. These segments have different recurrence intervals, with estimates of the recurrence interval for the KI segment being as low as 60 years (Johnson and others, 1996). On the basis of all published

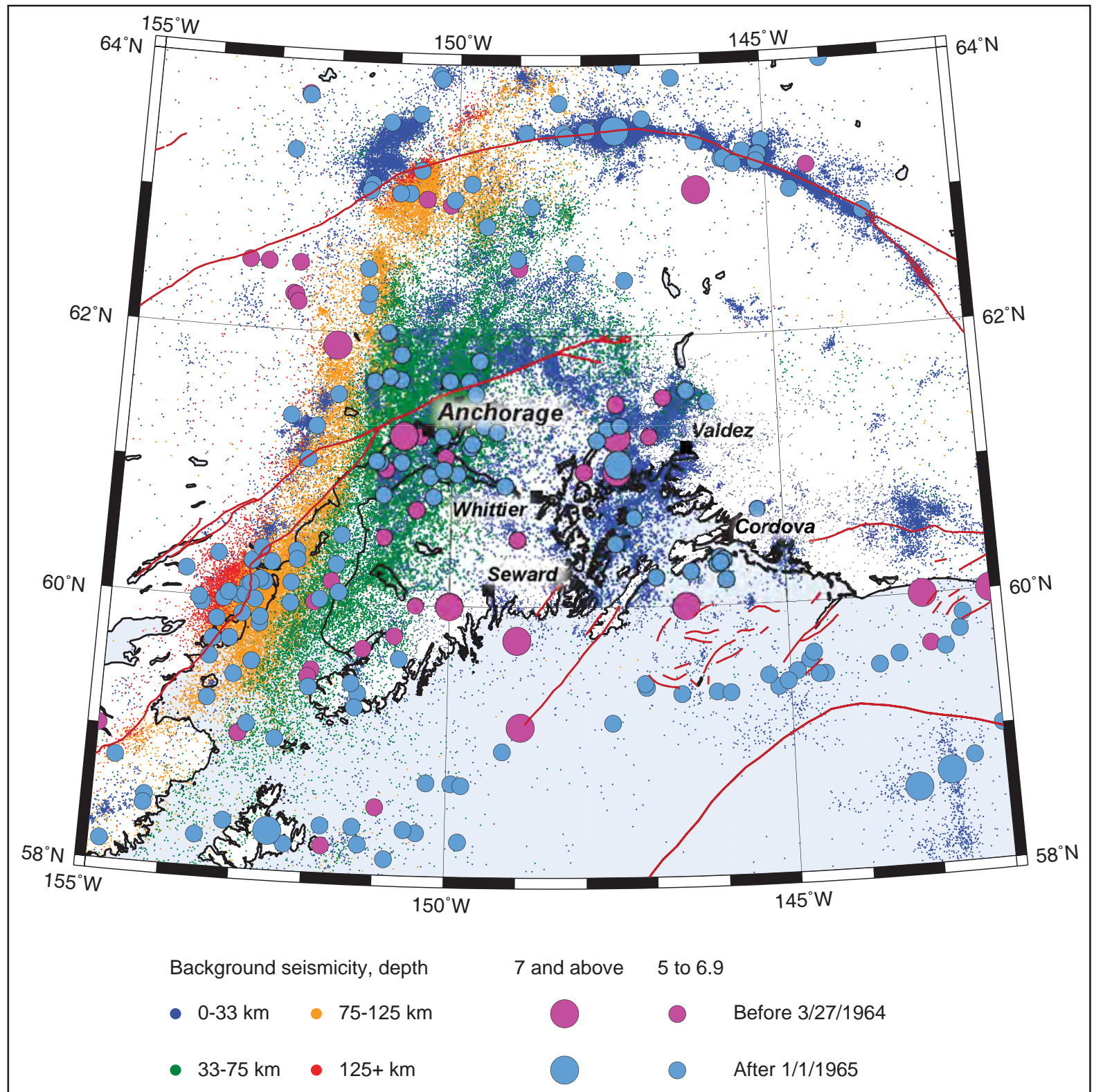

Figure 3. Earthquakes in south-central Alaska, from the Alaska Earthquake Information Center catalog. Small dots (barely visible) correspond to earthquakes with magnitude less than 5. Medium circles show significant earthquakes (magnitude 5 and greater) and large circles show powerful earthquakes before (purple) and after (light blue) the Great Alaska Earthquake of March 27, 1964. The main shock and aftershocks of that event are not included in the plot. 
paleoseismic data for the region, Carver and Plafker (2008) calculate that the median intervals between the past eight great earthquakes in the PWS segment of the eastern Aleutian seismic zone range from 333 to 875 years, and average 589 years.

The Yakataga-Yakutat area at the eastern end of the megathrust is a complex collision zone where the Yakutat microplate moves northwest toward central Alaska at $48 \mathrm{~mm} / \mathrm{yr}$ (Carver and Plafker, 2008). This segment translates the predominantly strike-slip motion on its eastern side to a shallow-dipping subduction on its west side (Nishenko and Jacob, 1990). The southern and eastern boundaries of the Yakutat block are well defined, but a collection of distributed fold and thrust zones, splay faults, and mountain-building regions complicates the northern and western edges of the block, as shown in figure 5 . We note that the interaction between the Yakutat block and the Pacific and North American plates is complex and poorly understood. Plafker and Thatcher (2008) reevaluated the mechanisms of the two great Yakutat Bay earthquakes of September 1899 and showed that coseismic deformation was onshore uplift, explaining the absence of a tsunami in the Gulf of Alaska. There were, however, several local tsunamis observed in bays and fjords that were triggered by submarine slides and collapses of glacier walls. Plafker and Thatcher (2008) conclude that the 1899 earthquake sequence most likely did not rupture through the offshore portion of the Yakataga seismic gap, a region between the 1964 rupture area and the focal area of the 1899 earthquakes. This finding suggests that the YY segment has a high potential for a future tsunamigenic earthquake.

In a paleoseismic study of regional land subsidence at Kenai Peninsula sites, Hamilton and Shennan (2005) estimated coseismic subsidence during the 1964 earthquake and two earlier events. It was shown that the earthquake dated to $1,500-1,400$ years BP produced more than twice the subsidence caused by the 1964 earthquake. By comparing the Kenai Peninsula sites with other sites around Cook Inlet, the authors find that each of the three great earthquakes in the study had a different pattern of coseismic subsidence. Recent work by Shennan and others (2008) tests the hypothesis that in some seismic cycles, megathrust segments can, as proposed in the segmentation model by Nishenko and Jacob (1990), rupture simultaneously to produce earthquakes greater than any in recorded history. Shennan and others (2008) present geologic evidence of six prehistoric

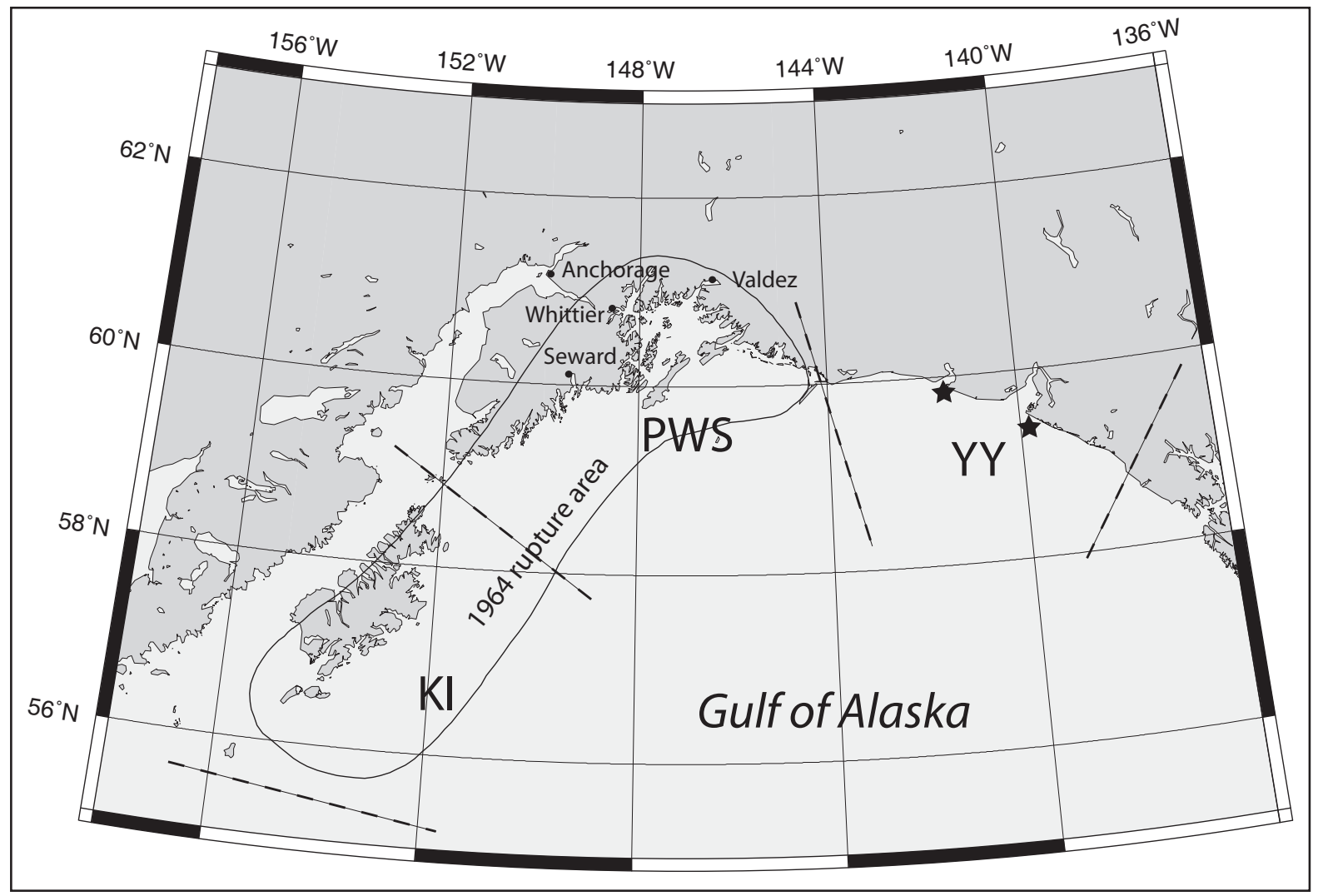

Figure 4. Map of south-central Alaska with the rupture zone of the 1964 Great Alaska Earthquake and segments of the Alaska-Aleutian megathrust: the Prince William Sound (PWS), Kodiak Island (KI) and Yakataga-Yakutat (YY) segments. Stars indicate epicenters of two earthquakes of September 1899. 


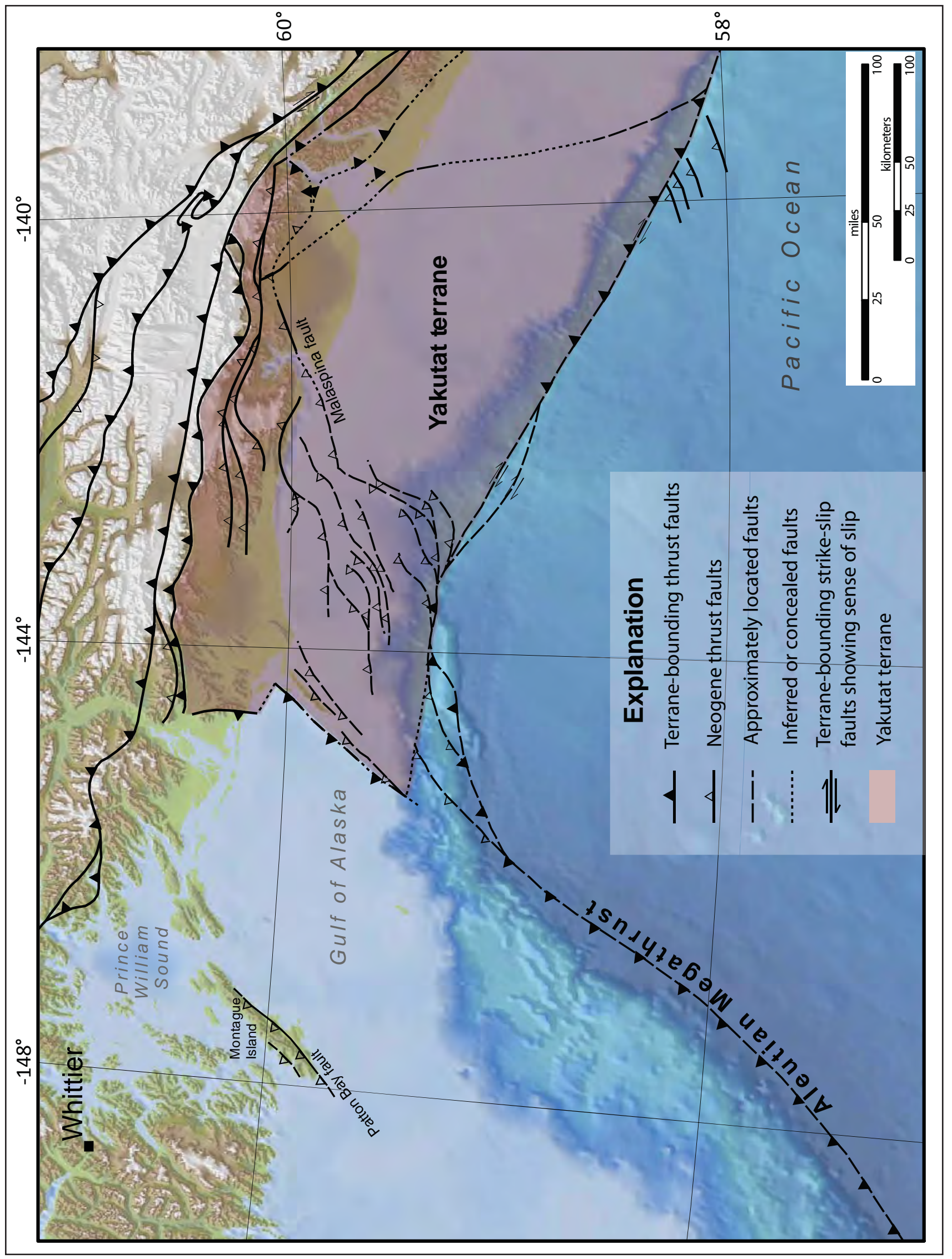

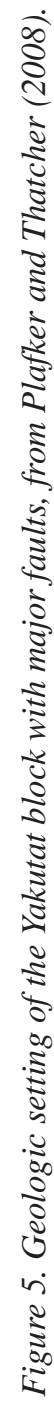


major tsunamigenic earthquakes in the Kenai Peninsula area of south-central Alaska in the past 4,000 years based on radiocarbon ages of tidal marsh deposits in Girdwood. Their paper presents paleoseismic evidence that earthquakes approximately 900 and 1,500 years BP simultaneously ruptured three adjacent segments of the Aleutian Megathrust: the PWS and KI segments, and the Yakutat microplate (the YY segment). The rupture area of these earthquakes was estimated to be $23,000 \mathrm{~km}^{2}$ greater than that of the $M_{w} 9.2$ Great Alaska Earthquake of 1964, and with a 15 percent larger seismic moment. This demonstrates that an understanding of the most recent great earthquakes in the area is insufficient for comprehensive tsunami hazard assessment in southcentral Alaska, and that detailed studies of multiple great earthquakes are required. We develop several hypothetical tsunamigenic earthquake models and describe them later in the text. For each model we perform a numerical modeling experiment to estimate the impact of tsunami waves on Whittier.

\section{LANDSLIDE TSUNAMI HAZARD IN PASSAGE CANAL}

Tsunamis caused by submarine slope failures are a serious hazard in glacial fjords such as Passage Canal. Massive underwater slope failures typically generate large waves that are usually observed while the ground is still shaking. A primary reason for submarine landslides is the accumulation of sediments on steep underwater slopes. Recent results of sediment chemistry monitoring in Port Valdez, located in a glacial fjord similar to Passage Canal, demonstrated high sediment accumulation rates of about $15 \mathrm{~mm}$ (0.6 in) per year at the head of Valdez Bay (Savoie and others, 2006). During an earthquake, dynamic forces imposed by seismic accelerations add to the gravitational force and consequently cause sliding of the unconsolidated sediments (Hampton and others, 2002). Lemke (1967), Wilson and Tørum (1968), Plafker and others (1969), and Shannon and Hilts (1973) conducted geologic investigations after the 1964 earthquake in numerous locations around south-central and southeastern Alaska. From these studies, we conclude that the major factors contributing to the total volume and aerial extent of the slide material are the duration of ground motion, the configuration of underwater slopes, and the type of sediment forming these slopes - unconsolidated or fine-grained materials. Hampton and others (1996) add that high artesian pressure within aquifers of the delta, combined with the extra load caused by waterfront artificial fill associate with shoreline development, also contributes to the slope failures. Further, Bornhold and others (2001) identify earthquakes, extreme low tides, and construction activities in ports and harbors as the most common triggering mechanisms for underwater slope failures.
Kulikov and others (1998) analyze tsunami catalog data for the north Pacific coast and show that southcentral and southeastern Alaska have a long recorded history of tsunami waves generated by submarine and subaerial landslides, avalanches, and rockfalls. The authors also found, in the majority of cases, that tectonic tsunamis arriving in bays and fjords from the open ocean had relatively small wave height, but a great number of local landslide-generated tsunamis had much larger wave height. For example, the landslide-generated tsunami in Whittier caused severe damage while the tectonic tsunami was not even noticed.

Bornhold and others (2001) address the problem of estimating the hazard of landslide-generated tsunami waves for British Columbia and Alaska coasts. Such estimation for a coastal community requires assessment of locations of potential underwater failures and the physical parameters of the underwater materials. The most probable locations of unstable sediment accumulations in the western part of Passage Canal are the slopes of the Whittier Creek delta, the moraine deposits at the head of the canal and along the northern coast, and artificial fills in the harbor area. Bornhold and others (2001) outline specific features for long-term prediction of landslide-generated tsunamis at selected sites, and develop a long-term approach for estimating potential tsunami inundation. The approach consists of two steps. First, it is necessary to analyze historical events and compare modeling results with observations at the physical site, and then simulate hypothetical tsunami scenarios. We follow Bornhold and others (2001) and employ their methodology to estimate the local tsunami hazard at Whittier.

\section{METHODOLOGY AND DATA}

\section{GRID DEVELOPMENT AND DATA SOURCES}

One of the challenges in tsunami modeling is that the governing equations for water dynamics are continuous. In this work, we discretize the shallow water equations in spherical coordinates on Arakawa C-grid using a finite difference method. To resolve a wave, the grid must be fine enough, with at least four points per wavelength (Titov and Synolakis, 1995), however, more points than that are often necessary to achieve satisfactory accuracy (for example, Titov and Synolakis, 1997). To compute a detailed map of potential tsunami inundation triggered by local and distant earthquakes, we employ a series of nested computational grids. A nested grid allows for higher resolution in areas where it is needed, without expending computer resources in areas where it is not. The bathymetric and topographic relief in each nested grid is based on digital elevation models (DEMs) developed at the National Geophysical 
Data Center (NGDC), National Oceanic \& Atmospheric Administration (NOAA), in Boulder, Colorado. The extent of each grid used for Whittier mapping is shown in figure 6 and listed in table 1. The coarsest grid, whose resolution is 2-arc-minute, or approximately $2 \mathrm{~km}$, spans the central and northern Pacific Ocean, while the highest resolution grid is localized near Passage Canal, including Shotgun Cove and a part of Blackstone Bay. The spatial resolution of the high-resolution grid satisfies NOAA minimum recommended requirements for computation of tsunami inundation (National Tsunami Hazard Mapping Program [NTHMP], 2010).

The bathymetry data for the 2-arc-minute resolution grid, whose extent is shown in figure 6 , is extracted from the ETOPO2 data set (NOAA, National Geophysical Data Center). To develop 15m, 8/3-, 8- and 24- arcsecond resolution grids, shoreline, bathymetric, and topographic digital datasets were obtained from several U.S. federal and academic agencies, including: NOAA's National Ocean Service (NOS), Office of Coast Survey, and NGDC; the U.S. Fish and Wildlife Service (FWS); the U.S. Geological Survey (USGS); and the U.S. Army Corps of Engineers (USACE). All data were shifted to World Geodetic System 1984 (WGS 84) horizontal and Mean Higher High Water (MHHW) vertical datums. The FWS statewide Alaska digital coastline was employed to create a coastline of the Prince William Sound region. Bathymetric datasets used in the compilation of the Prince William Sound DEMs included NOS hydrographic surveys, a recent USACE harbor survey, NOAA Electronic Navigational Charts, multibeam swath sonar surveys, and NGDC trackline surveys. Topographic datasets of Prince William Sound were obtained from the USGS National Elevation Dataset 2-arc-second gridded topography and 1-arc-second NASA Space Shuttle Radar Topography. The data sources and methodology used to develop high resolution, 8/3-, 8-, and 24-arc-second DEMs are described in great detail by Caldwell and others (2009); Lim and others (2009).
Accuracy of the high-resolution DEM developed by NOAA is determined by the topographic datasets with the vertical accuracy of 10-15 m(33-50 ft) (Caldwell and others, 2009). Since the DEM can posses large vertical errors near the shoreline, prediction of the potential inundation can be inaccurate. Hence, the topographic datasets are augmented with high-accuracy data, that is, a real time kinematic (RTK) GPS survey within the harbor area and along near-shore areas in Whittier. The survey was conducted November 13-14, 2009, and locations of the GPS measurements are shown as red triangles in figure 7. The collected GPS measurements had 0.03-0.05 $\mathrm{m}$ (1.2-2 in) lateral and vertical accuracy with respect to the so-called base station (Leica Geosystem AG, 2002). Therefore, to achieve sub-meter accuracy of all GPS measurements with respect to the MHHW datum, the relative position of the base station must be determined with respect to the MHHW datum with sub-meter accuracy. Such base-station accuracy can be achieved if the base station is located at a well known benchmark or monument. Since access to the benchmark in Whittier was restricted, we used the following technique to establish the vertical datum.

During the survey, at some partially enclosed locations, such as the small boat harbor, where the water level was relatively constant, we took GPS measurements of the sea surface height, schematically shown by the red arrow in figure 8a. Sea level was measured at low and high tides as well as at some intermediate tide stages. Then we computed the difference, denoted by $\mathrm{H}_{2}$, between the GPS elevations of the sea level and the elevation of the base station, shown by the blue arrow. Since all GPS measurements have several centimeter accuracy relative to each other, dynamics of the tide level, $\mathrm{H}_{2}$, with respect to the base station is also known to have an accuracy of several centimeters. Given the tide level, $\mathrm{H}_{1}(\mathrm{t})$, with respect to the MHHW datum (predictions by NOAA, http://tidesandcurrents.noaa.gov/), it is easy to calculate the vertical shift between MHHW and base

Table 1. Nested grids used to compute propagation of tsunami waves generated in the Gulf of Alaska to the city of Whittier. The high-resolution grid is used to compute the inundation. Note that the grid resolution in meters is not uniform and is used to illustrate grid fineness near Whittier. The first dimension is the longitudinal grid resolution, while the second is the latitudinal grid resolution.

\begin{tabular}{|c|c|c|c|c|}
\hline \multirow{2}{*}{$\begin{array}{c}\text { Grid } \\
\text { name }\end{array}$} & \multicolumn{2}{|c|}{ Resolution } & \multirow[b]{2}{*}{$\begin{array}{l}\text { West-East } \\
\text { boundaries }\end{array}$} & \multirow[b]{2}{*}{$\begin{array}{c}\text { North-South } \\
\text { boundaries }\end{array}$} \\
\hline & $\begin{array}{c}\text { arc- } \\
\text { seconds }\end{array}$ & $\begin{array}{c}\text { meters } \\
\text { (near Whittier) }\end{array}$ & & \\
\hline Northern Pacific & $2^{\prime} \times 22^{\prime}$ & $1,850 \times 3,700$ & $120^{\circ} 00^{\prime} \mathrm{E}-100^{\circ} 00^{\prime} \mathrm{W}$ & $10^{\circ} 00^{\prime} \mathrm{N}-65^{\circ} 00^{\prime} \mathrm{N}$ \\
\hline Kodiak-Kenai & $24 ” \times 24 ”$ & $370 \times 740$ & $145^{\circ} 00^{\prime} \mathrm{W}-156^{\circ} 00^{\prime} \mathrm{W}$ & $55^{\circ} 00^{\prime} \mathrm{N}-62^{\circ} 00^{\prime} \mathrm{N}$ \\
\hline Coarse PWS & 8” x 8” & $120 \times 245$ & $145^{\circ} 00^{\prime} \mathrm{W}-150^{\circ} 00^{\prime} \mathrm{W}$ & $58^{\circ} 30^{\prime} \mathrm{N}-61^{\circ} 30^{\prime} \mathrm{N}$ \\
\hline Fine PWS & 8/3” x 8/3” & $40 \times 82$ & $145^{\circ} 20^{\prime} \mathrm{W}-148^{\circ} 46^{\prime} \mathrm{W}$ & $59^{\circ} 40^{\prime} \mathrm{N}-61^{\circ} 20^{\prime} \mathrm{N}$ \\
\hline High resolution & $8 / 9 ” \times 8 / 15 ”$ & $14 \times 16$ & $148^{\circ} 45^{\prime} \mathrm{W}-148^{\circ} 30^{\prime} \mathrm{W}$ & $60^{\circ} 45^{\prime} \mathrm{N}-60^{\circ} 51^{\prime} \mathrm{N}$ \\
\hline
\end{tabular}




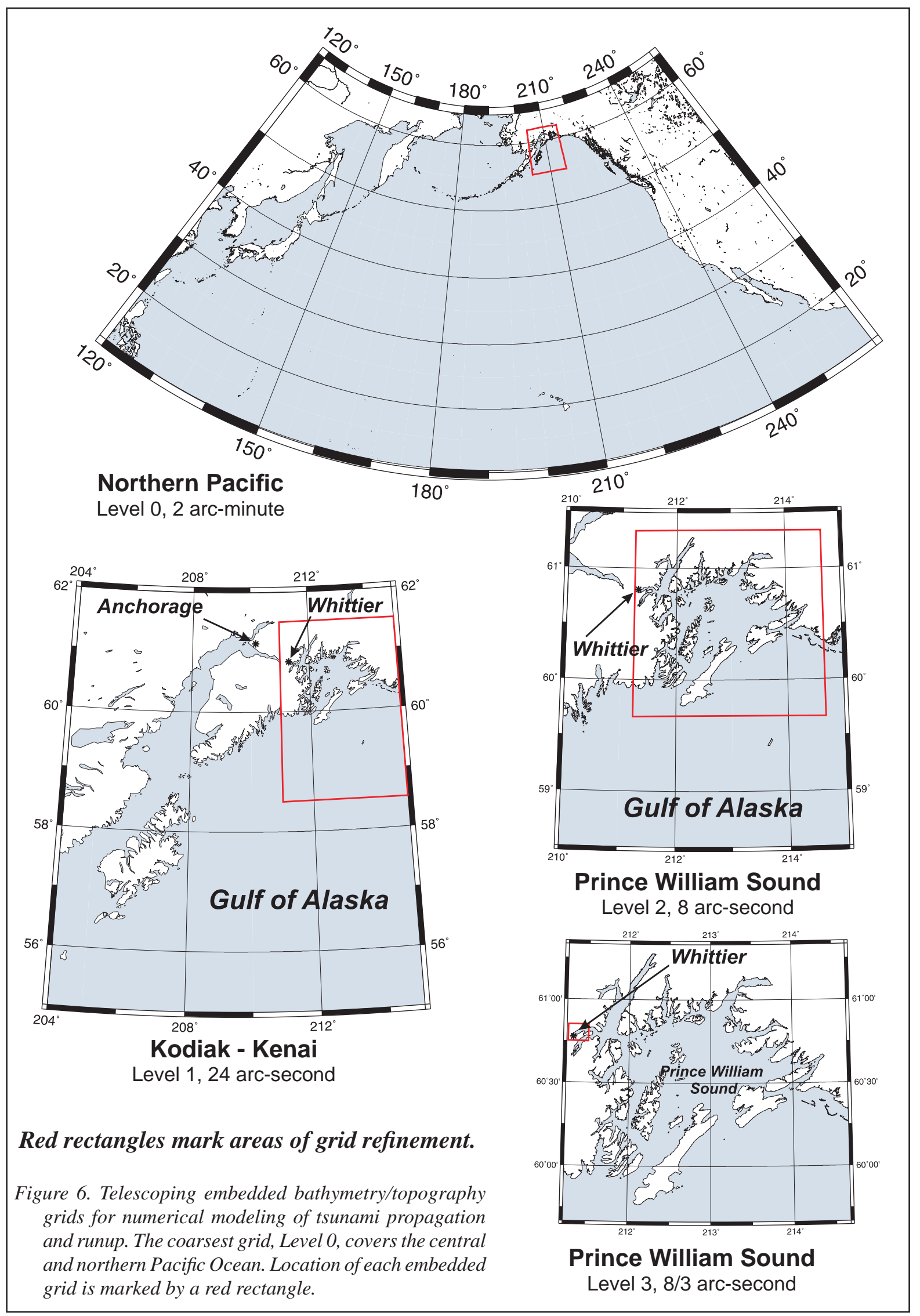




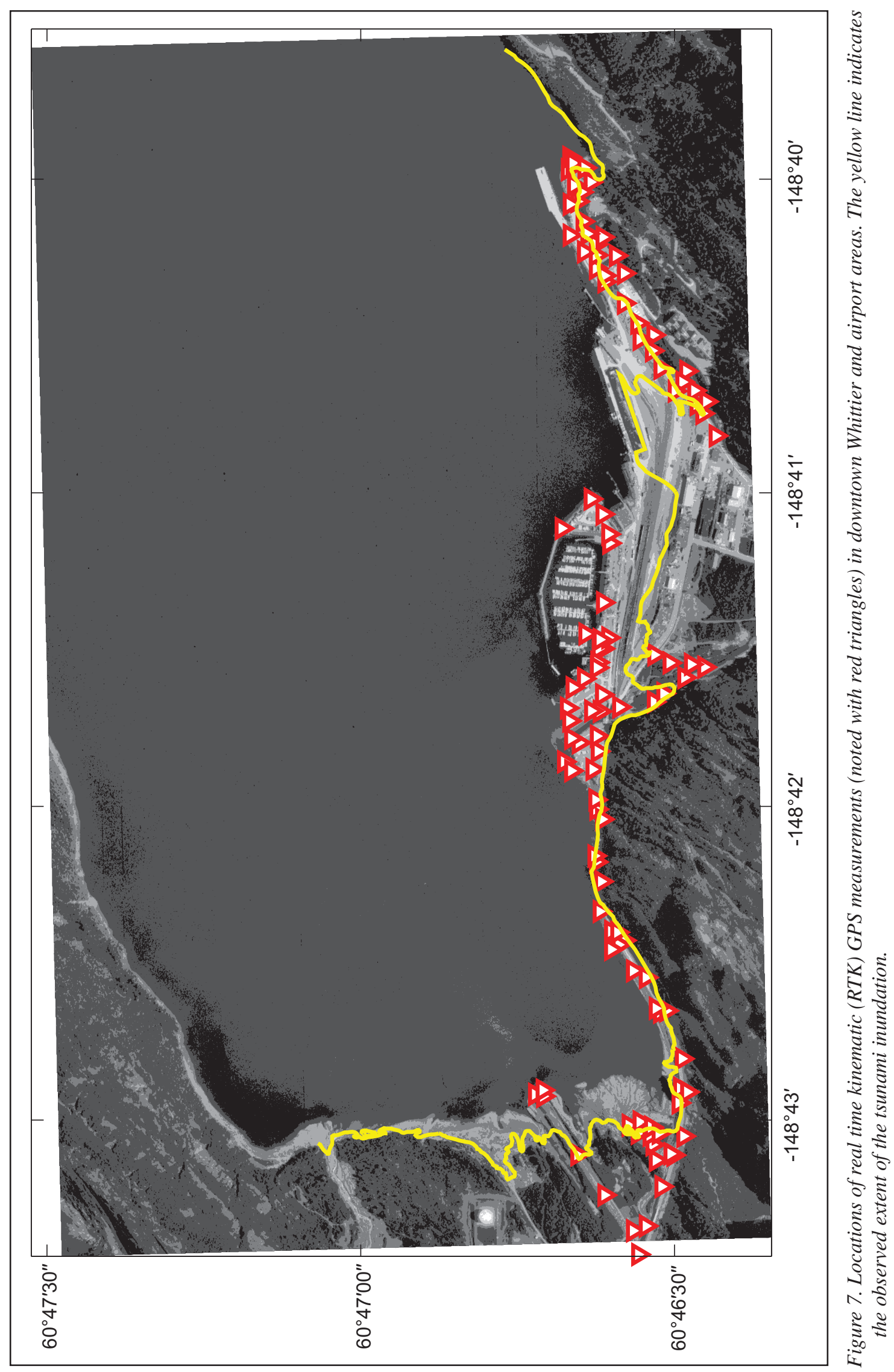




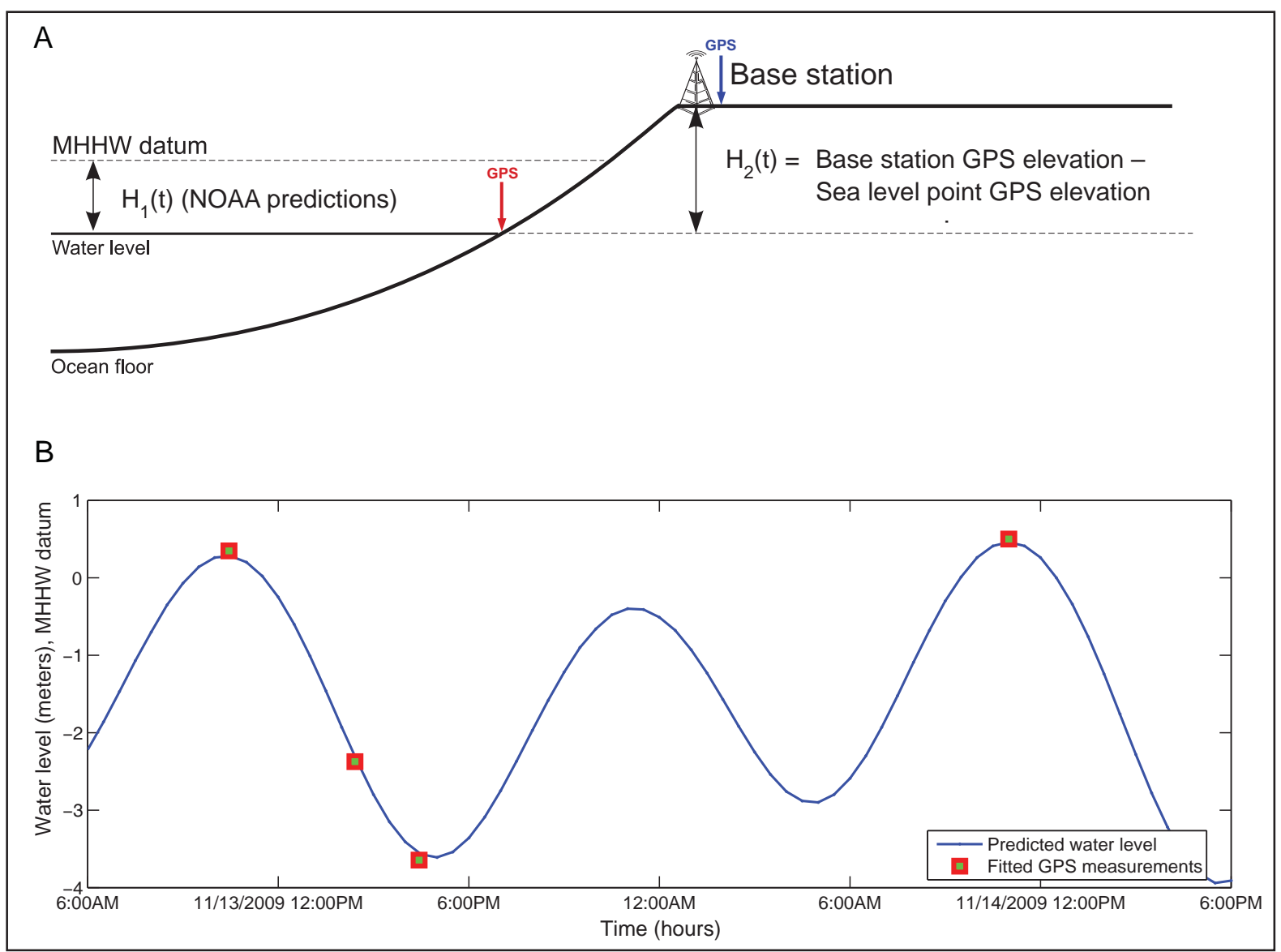

Figure 8. A. Measurement of sea level in the WGS84 datum and the relation of the WGS84 datum to the MHHW datum. B. Predicted water level dynamics in Whittier and the fitted GPS measurements of the water level in the MHHW datum.

station datums by fitting the measured sea heights to the predicted ones, as shown in figure $8 \mathrm{~b}$. We apply the same shift to all collected GPS measurements, and thus convert the entire survey to the MHHW datum.

We emphasize that the accuracy of converting the survey to the MHHW datum depends on the accuracy of NOAA's Tides and Currents prediction. Comparison of the tide data at Cordova and Valdez to the corresponding NOAA predictions shows that the deviation is less than $0.6 \mathrm{~m}$ (2 ft). The largest discrepancy on November 14, 2009, was $0.45 \mathrm{~m}(1.5 \mathrm{ft})$ at Cordova and $0.20 \mathrm{~m}(0.7$ $\mathrm{ft}$ ) at Valdez. We hypothesize that the error between the actual and predicted tides is approximately the same in Whittier. Hence, we estimate that the error of converting the observations to the MHHW datum does not exceed $1 \mathrm{~m}$ (3.3 ft) in flat-lying areas where there are no abrupt topographic changes. Finally, we note that the collected GPS measurements are recorded in WGS84 horizontal datum, with the horizontal accuracy of approximately 3-5 m (10-16 ft) (Leica Geosystem AG, 2002). We interpolate between the collected measurements in certain areas of flat topography such as the railroad tracks, harbor parking area, and ferry terminal, taking into account relatively sparse distribution of the GPS measurements. In figure 9, we show the original and adjusted DEMs within the Whittier downtown area. Note that the harbor parking area, railroad depot, and tracks have a more uniform horizontal level and are more realistic (City Manager M. Earnest, oral commun. during 2009 visit to Whittier).

\section{NUMERICAL MODEL OF TSUNAMI WAVE PROPAGATION AND RUNUP}

NOAA recently published a technical memorandum that outlines major requirements for numerical models used in inundation mapping and tsunami forecasting, and describes a procedure for model evaluation (Synolakis and others, 2007). There are two major components to this process. The first is model validation, which ensures that the model correctly solves appropriate equations of motion by comparing model results with known solutions. This is achieved through analytical and laboratory 


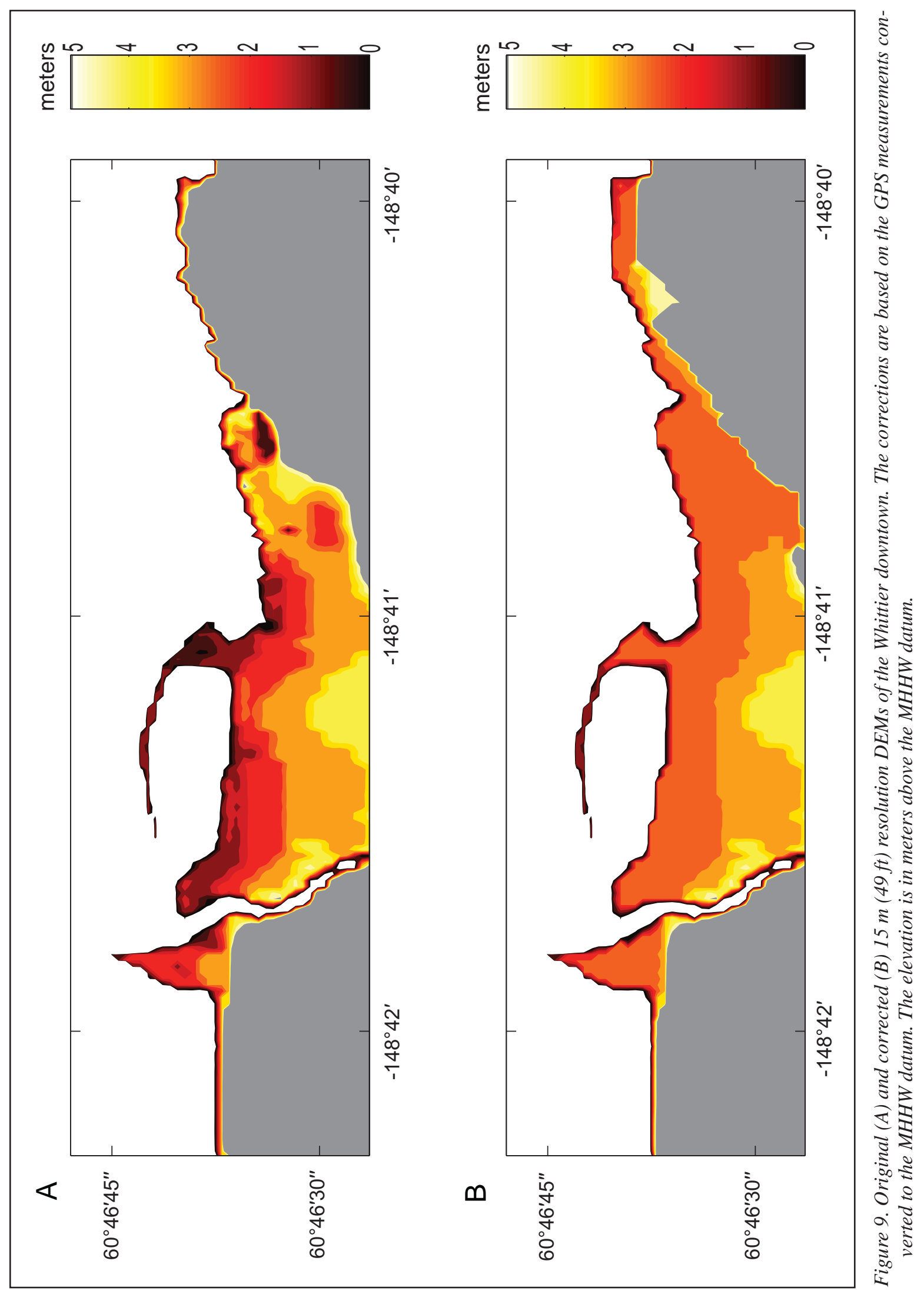


benchmarking. The second component is model verification, or testing the model, using observations of real events through field data benchmarking.

The numerical model that is currently used by the Alaska Earthquake Information Center (AEIC) for tsunami inundation mapping has been validated through a set of analytical benchmarks, and tested against laboratory and field data (Nicolsky and others, 2011). The model solves nonlinear shallow water equations using a finite-difference method on a staggered grid. For any coarse-fine pair of computational grids, we apply a time explicit numerical scheme as follows. First, we compute the water flux within a coarse-resolution grid. These calculated flux values are used to define the water flux on a boundary of the fine-resolution grid. Next, the water level and then the water flux are calculated over the fine-resolution grid. Finally, the water level computed in the fine-resolution grid is used to define the water level within the area of the coarse-resolution grid that coincides with the fine grid. Despite the fact that nested grids decrease the total number of grid cells needed to preserve computational accuracy within certain regions of interest, actual simulations are still unrealistic if parallel computing is not implemented. Here, we use the Portable Extensible Toolkit for Scientific computation (PETSc), which provides sets of tools for the parallel numerical solution of shallow water equations. In particular, each computational grid listed in table 1 can be subdivided among an arbitrary number of processors. The above-mentioned passing of information between the water flux and level is implemented efficiently using PETSc subroutines.

We assess hazards related to tectonic and landslidegenerated tsunamis in Passage Canal by performing model simulations for each hypothetical earthquake and landslide source scenario. In the output of the numerical model, each of the grid points has either a value of 0 if no inundation occurs or 1 if seawater reaches the grid point at any time. The inundation line approximately follows the 0.5 contour between these 0 - and 1-point values but was adjusted visually to accommodate obstacles or local variations in topography not represented by the DEM. Although the developed algorithm has passed through the rigorous benchmarking procedures (Nicolsky and others, 2011), the uncertainty in a location of the inundation line is still present. However, this uncertainty is to a greater degree unknown because the inundation line is the result of a complex modeling process. Affecting the accuracy of the inundation line are many factors on which the model depends, including suitability of the earthquake source model, accuracy of the bathymetric and topographic data, and the adequacy of the numerical model in representing the generation, propagation, and runup of tsunami waves. In this report, we do not attempt to adjust the modeled inundation limits to account for these uncertainty factors.

We note that there are several limitations of the model. One of importance is that it does not take into account the periodic change of sea level due to tides. We conducted all model runs using bathymetric data that correspond to MHHW, with the exception of numerical modeling of the 1964 tsunami for the purpose of model validation. The 1964 runs were conducted using the stage of tide at the time of the earthquake, approximately Mean Low Water. For the generation mechanism, we modeled earthquakes and landslides as potential sources of tsunami waves. In this region, it was important to include landslide tsunami sources because underwater landslides and their resultant tsunamis caused a significant portion of the damage in Passage Canal during the 1964 Great Alaska Earthquake.

\section{NUMERICAL MODEL OF LANDSLIDE- GENERATED TSUNAMI WAVES}

To simulate tsunami waves produced by multiple underwater slope failures in Passage Canal on March 27, 1964, we used a numerical model of a viscous underwater slide with full interactions between the deforming slide and the water waves that it generates. This model was initially proposed by Jiang and LeBlond (1992). Fine and others (1998) improved the model by including realistic bathymetry, and by correcting errors in the governing equations. The Fine model's assumptions and applicability to simulating underwater mudflows are discussed by Jiang and LeBlond $(1992,1994)$ in their formulation of the viscous slide model. The model uses long-wave approximation for water waves and the deforming slide, which means that the wavelength is much greater than the local water depth, and the slide thickness is much smaller than the characteristic length of the slide along the slope (Jiang and LeBlond, 1994). Assier-Rzadkiewicz and others (1997) argued that the long-wave approximation could be inaccurate for steeper slopes exceeding 10 degrees. Rabinovich and others (2003) studied the validity of the long-wave approximation for slopes greater than 10 degrees and found that for a slope of 16 degrees, the possible error was 8 percent, and for the maximum slope in their study of 23 degrees, the possible error was 15 percent. Since the average pre-earthquake offshore slopes from 10 to 30 degrees in the vicinity of Whittier, the possible error introduced by a slide moving down these higher gradient slopes could be significantly higher, and further scientific studies are necessary.

The advantage of the vertically integrated model by Jiang and LeBlond (1992) is its ability to simulate runup of real landslide tsunami events using high-resolution numerical grids. Although model runs require the use 
of high-performance computing, the computational times are still reasonable. This model was successfully applied to simulate a tsunami event in Skagway Harbor, one of numerous fjords in southeastern Alaska, where tsunami waves were generated by a submarine landslide on November 3, 1994 (Fine and others, 1998; Thomson and others, 2001). The results of numerical simulations were in good agreement with the tide gauge record in Skagway Harbor. Rabinovich and others (2003) simulated potential underwater landslides in British Columbia fjords, with settings similar to Passage Canal, and demonstrated that this model can also be used for tsunami hazard assessment.

\section{TECTONIC TSUNAMI SOURCES}

One of the most destructive tectonic tsunamis in Alaska history was triggered by the 1964 Great Alaska Earthquake, during which the Prince William Sound (PWS) and Kodiak Island (KI) segments ruptured simultaneously (Christensen and Beck, 1994). Shennan and others (2009) present geologic evidence that the PWS and KI segments of the 1964 rupture area and a portion of the Yakutat microplate ruptured simultaneously in the past, and could have produced more devastating tsunamis. Another hypothetical tsunamigenic earthquake worth considering is a rupture of the Cascadia subduction zone, involving the Juan de Fuca Plate underlying the Pacific Ocean, from mid-Vancouver Island in British Columbia, southwest Canada, along the Pacific Northwest coast.

Before we begin describing all tsunami sources that were considered, we note some assumptions in our modeling technique. First, an initial displacement of the ocean surface is equal to the vertical displacement of the ocean floor induced by the earthquake rupture process. Second, the finite speed of the rupture propagation along the fault is not taken into account. We consider the ocean bottom displacement to be instantaneous. Third, the initial topography is modified to account for coseismic deformation of land due to the earthquake.

\section{Models of the 1964 Great Alaska Earthquake}

The 1964 tsunami was generated in the trench and upper-plate fold-and-thrust belt area of the subduction zone (Plafker and others, 2000). It affected numerous communities along the Pacific Northwest coast, Hawaii, and Alaska. This tsunami was studied in depth by several investigators (Plafker, 1967; Wilson and Tørum, 1968; Lemke, 1967). Plafker (1967) gives a detailed description of the motion observed on the Patton Bay fault during the Great Alaska Earthquake of 1964, and provides a full report of the surface rupture and fault motion, as well as several pieces of evidence suggesting that the fault continues on the ocean floor well past the region where it is currently mapped. Holdahl and Sauber
(1994) applied Plafker's description to construct their model of the Patton Bay fault, which was used in an inversion of geodetic data. Johnson and others (1996) used the results of Holdahl and Sauber (1994) to augment their joint inversion of geodetic and tsunami data and to further reconstruct coseismic deformation models of the 1964 earthquake.

In this study, we use two coseismic deformation models of the 1964 earthquake, the Johnson and others (1996) and the Suito and Freymueller (2009) models to generate the vertical displacements of the sea floor during the earthquake. We hereafter reference Johnson and others (1996) as the Johnson deformation model (JDM) and Suito and Freymueller (2009) as the Suito deformation model (SDM).

Johnson and others (1996) derive a detailed slip distribution for the 1964 earthquake, which has eight subfaults representing the KI asperity and nine subfaults in the PWS asperity. One subfault was assigned to represent the Patton Bay fault. Johnson and others (1996) and Holdahl and Sauber (1994) used only the mapped extent of the fault, approximately $72 \mathrm{~km}$, despite evidence suggesting that the fault may extend much farther to the southwest. For example, Suito and Freymueller (2009) found that they could not fit all the GPS data accurately unless they extended the fault past the tip of the Kenai Peninsula. In the same report, Suito and Freymueller (2009) develop a coseismic deformation model of the 1964 earthquake based on a three-dimensional (3-D) viscoelastic model, which implements a realistic geometry with an elastic slab having low dip angle. This coseismic model is not based on an inversion, but it resembles a recently published inversion model (Ichinose and others, 2007) as well as some previously proposed models (Holdahl and Sauber, 1994; Johnson and others, 1996; Santini and others, 2003).

The main difference between JDM and SDM is that the latter incorporates slightly higher slip near the downdip end of the rupture, to explain the horizontal displacements. Additionally, the rupture in the SDM is assumed to occur deeper than in the JDM. Consequently, the deeper subfaults in the SDM produce smoother variation of the sea floor deformation than in the JDM. Both models introduce the Patton Bay splay fault to explain the excessive uplift at Montague Island. It is assumed in the JDM that the extent of this splay fault was not much larger than its subaerial outcrop on Montague Island. On the other hand, it is assumed in the SDM that the same fault extends much farther to the west than was previous assumed by Holdahl and Sauber (1994) and Johnson and others (1996). We note that although the Patton Bay fault slipped approximately $10 \mathrm{~m}$ (33 ft) at the southwestern tip of Montague Island, there has yet to be a comprehensive submarine survey to document the extent of that splay fault. 
Scenario 1. Repeat of the 1964 event: Source function based on coseismic deformation model by Johnson and others (1996) (JDM)

The 1964 earthquake vertical coseismic displacement is modeled as rupture by eight subfaults representing the Kodiak asperity and nine subfaults in the Prince William Sound asperity. One subfault was assigned to represent the Patton Bay fault, although the contribution of this fault to the far-field tsunami waveform was negligible. The fault parameters required to compute sea floor deformation are the epicenter location, area, dip, rake, strike, and amount of slip on the fault. We use the equations of Okada (1985) to calculate distribution of coseismic uplift and subsidence resulting from this slip distribution. This source function was previously applied to calculation of 1964 tsunami inundation in Kodiak and Kachemak Bay communities. The results are described in Suleimani and others $(2002,2005)$. The vertical ground/ocean floor displacement according to the JDM is shown in figure 10 .

Scenario 2. Repeat of the 1964 event: Source function based on coseismic deformation model by Suito and Freymueller (2009) (SDM)

This coseismic deformation model of the 1964 earthquake is based on a 3-D viscoelastic model, incorporating a realistic geometry with an elastic slab having low dip angle. The vertical ground/ocean floor displacement according to the SDM is shown in figure 10 .

\section{Models of the multi segment Great Alaska Earthquake}

A recent study by Shennan and others (2008) presents geologic evidence that the Prince William Sound and Kodiak Island segments of the 1964 rupture area and a portion of the Yakutat microplate may rupture simultaneously. To evaluate whether this event would make a plausible tsunami scenario for Whittier, we have constructed a source function of the multi-segment rupture that encompasses the 1964 rupture.

We apply the following constraints based on the hypothetical earthquake model of Shennan and others (2008). The extended source function includes three segments of the Aleutian megathrust: the Prince William
Sound (PWS), Kodiak Island (KI), and YakatagaYakutat (YY) segments. The total seismic moment is about 15 percent greater than that of the 1964 earthquake. The new source function produces coseismic vertical uplifts along the Gulf of Alaska coastline segment between the Copper River basin and Yakataga area, in order to match the coseismic deformation pattern to paleoseismic data (Shennan and others, 2008).

To construct a rupture model for the YY segment, we assume four subfaults whose parameters are listed in table 2. We calculate coseismic deformations produced by this segment using Okada's algorithm (Okada, 1985), and then combine them with the 1964 coseismic deformations produced either by the JDM or by the SDM.

\section{Scenario 3. Multi-segment JDM event: Source function based on extension of the JDM \\ The model in scenario 1 is extended by including a rupture model for the YY segment. The coseismic deformation pattern for the extended 1964 rupture is shown in figure 10.}

Scenario 4. Multi-segment SDM event: Source function based on extension of the SDM

The model in scenario 2 is extended by including a rupture model for the YY segment. The coseismic deformation pattern for the extended 1964 rupture is shown in figure 10.

\section{Model of the Cascadia Subduction Zone Earthquake}

Paleoseismic records reveal that great tsunamigenic earthquakes repeatedly occur in the Cascadia subduction zone with irregular intervals averaging about 500 years (Atwater, 1987), often accompanied by a tsunami. The latest trans-Pacific tsunami generated by an earthquake at Cascadia occurred in January 1700 (Satake and others, 1996; Atwater and others, 2005). Probably owing to low population density along the Alaska coast, the impact of this tsunami on local communities was not noticed. Multiple models of the Cascadia zone rupture are suggested by Satake and others (2003) and Priest and others (2009) and in references therein. These models describe hypothetical coseismic displacement

Table 2. Fault parameters for the Yakataga-Yakutat (YY) segment

\begin{tabular}{|c|c|c|c|c|c|c|c|c|}
\hline $\begin{array}{c}\text { Lat } \\
\text { (deg. N) }\end{array}$ & $\begin{array}{c}\text { Long } \\
\text { (deg. W) }\end{array}$ & $\begin{array}{c}\text { Depth } \\
\text { (km) }\end{array}$ & $\begin{array}{c}\text { Length } \\
\text { (km) }\end{array}$ & $\begin{array}{l}\text { Width } \\
\text { (km) }\end{array}$ & $\begin{array}{l}\text { Strike } \\
\text { (deg.) }\end{array}$ & $\begin{array}{l}\text { Dip } \\
\text { (deg.) }\end{array}$ & $\begin{array}{l}\text { Rake } \\
\text { (deg.) }\end{array}$ & $\begin{array}{l}\text { Slip } \\
\text { (m) }\end{array}$ \\
\hline 59.17 & 144.12 & 1 & 50.1 & 190 & 256 & 12 & 90 & 15 \\
\hline 59.36 & 143.23 & 3 & 51.1 & 141 & 250.4 & 10 & 90 & 15 \\
\hline 59.54 & 142.42 & 5 & 47.8 & 114.8 & 245.8 & 6 & 90 & 15 \\
\hline 59.94 & 141.21 & 5 & 79.7 & 99.6 & 237.8 & 8 & 90 & 15 \\
\hline
\end{tabular}




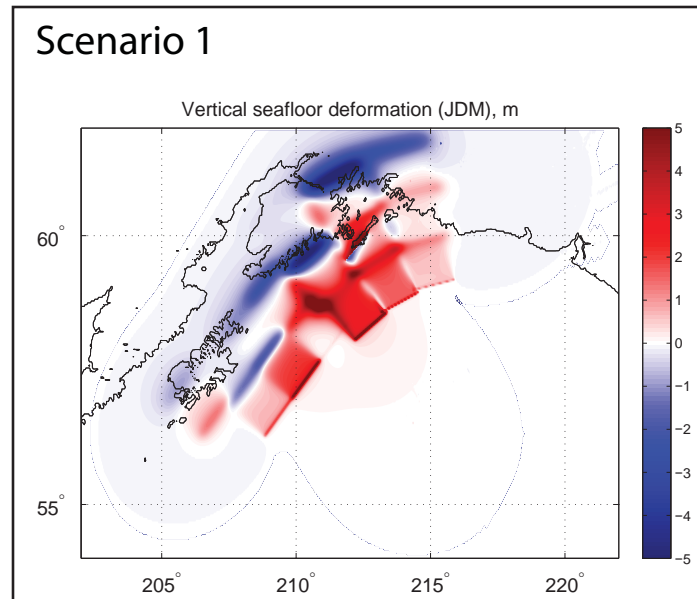

\section{Scenario 2}

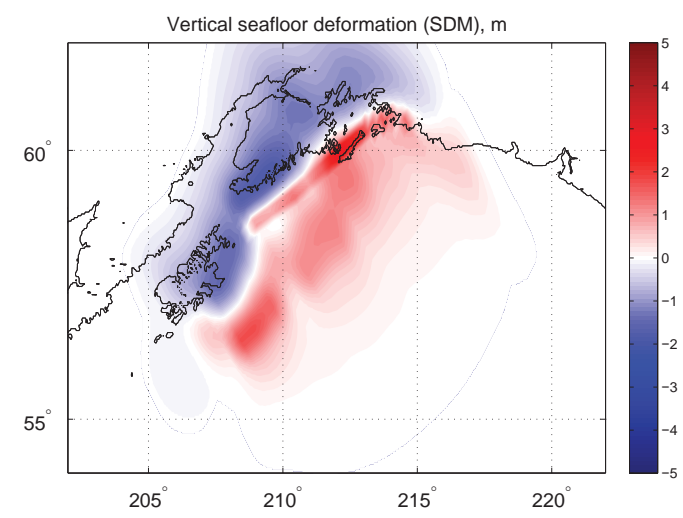

\section{Scenario 3}

Vertical seafloor deformation (Extended 1964 rupture based on the JDM), $m$

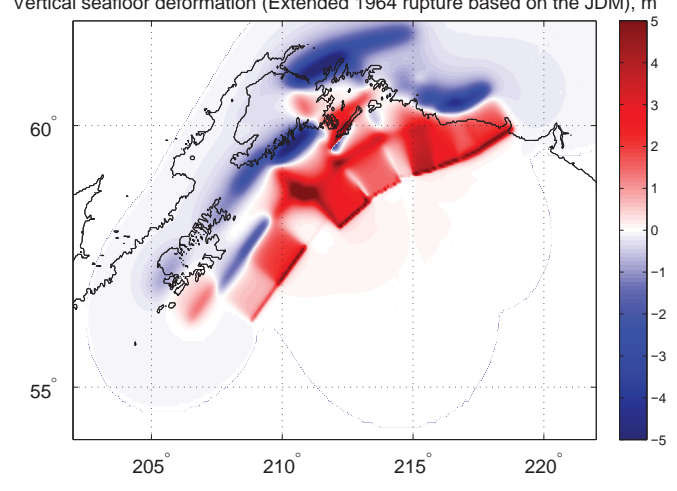

\section{Scenario 4}

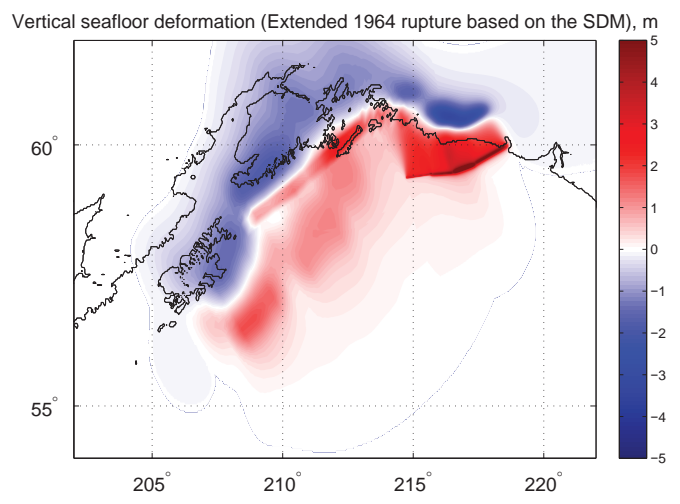

\section{Scenario 5}

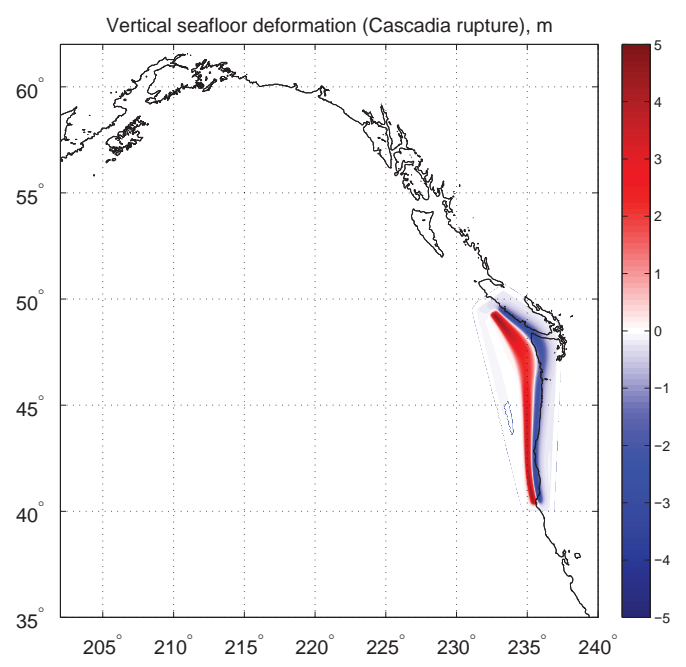

\section{Scenario 6}

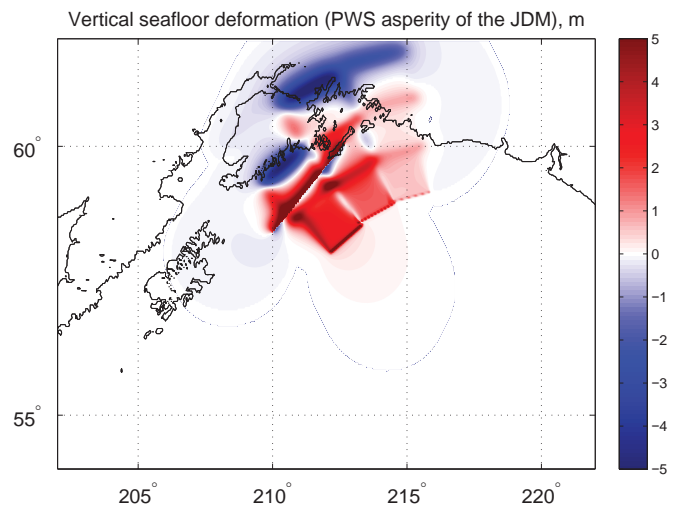

Figure 10. Vertical deformations of the ocean floor corresponding to scenarios 1-9. 


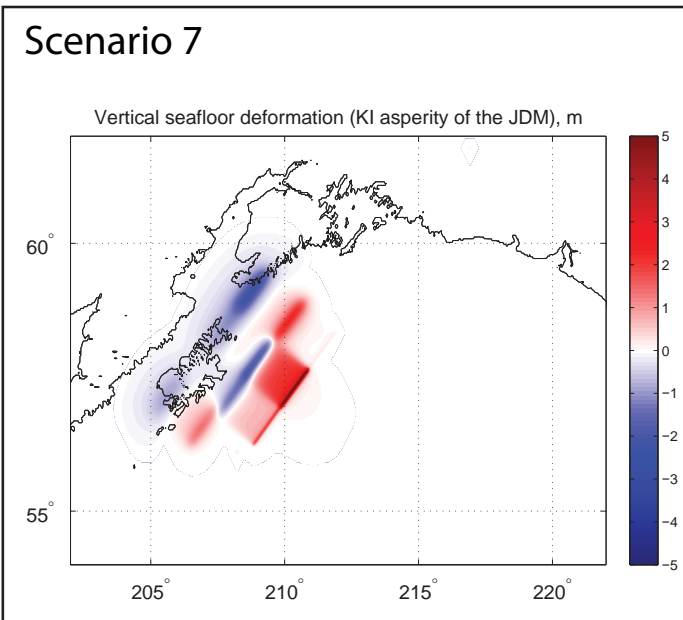

\section{Scenario 8}

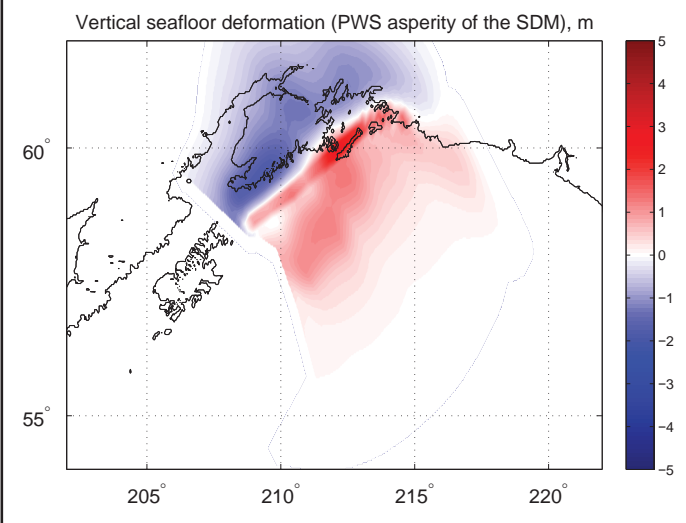

\section{Scenario 9}

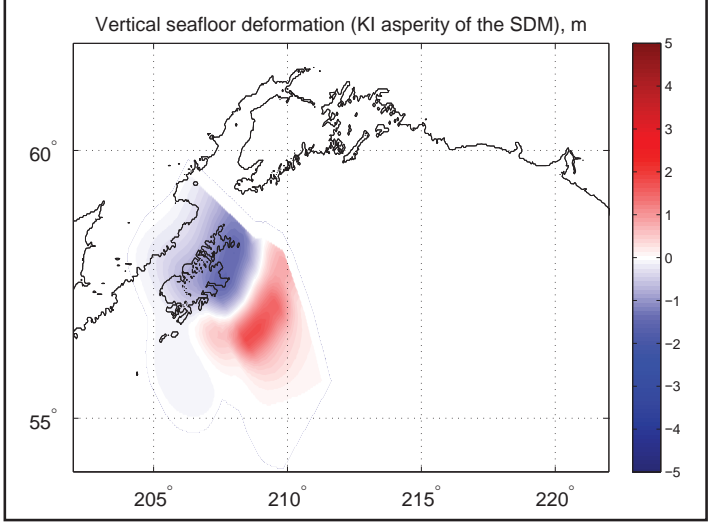

Figure 10 (cont'd). Vertical deformations of the ocean floor corresponding to scenarios 1-9. fields of the Cascadia rupture, with various levels of detail. Since the Cascadia subduction zone earthquake is considered to be a medium field tsunami source to the south-central Alaska coast, a relatively simple "worst case, but credible” rupture of the Cascadia subduction zone is used in this report.

Scenario 5. Rupture of the Cascadia zone, including portions of the margin along the British Columbia and northern California shores

Tsunami heights in Japanese historical records can constrain the slip distance of the 1700 Cascadia earthquake (Satake and others, 1996) but do not well constrain the downdip limit of the rupture (Wang and others, 2003). A conservative approach for Cascadia is to assume that full coseismic rupture takes place over the entire locked zone and the slip decreases linearly downdip halfway into the present effective transition zone. The most recently updated and probably more reasonable model assumes that the slip distribution in the downdip direction is bell shaped (Geological Survey of Canada, K. Wang, written commun., 2010), which is different from what was used to model the coseismic deformation shown in figure 14 of Wang and others (2003). In this report, the assumed rupture recovers 1,200 years equivalent of plate convergence (Oregon Department of Geology and Mineral Industries, R. Witter, oral commun., 2010), about $36 \mathrm{~m}$ (120 ft) slip and its magnitude $\mathrm{M}_{\mathrm{w}} \approx 9$ and is shown in figure 10 .

\section{Source models of hypothetical tsunamigenic earthquakes}

The results of joint inversion of tsunami and geodetic data from the 1964 earthquake (Johnson and others, 1996) support the division of the rupture zone into two different segments: the Kodiak block and the Prince William Sound (PWS) block. These zones have different recurrence intervals, with estimates of the recurrence interval for the Kodiak segment being as low as 60 years (Johnson and others, 1996). Therefore, we consider four scenarios in which these two segments of the 1964 rupture area are separate hypothetical tsunami sources.

Scenario 6. Modified 1964 event: Prince William Sound asperity of the JDM

This event is a hypothetical earthquake that ruptures nine subfaults of the Prince William Sound asperity with some slip on the Patton Bay fault from the deformation model by Johnson and others (1996). Vertical coseismic deformations for this scenario are shown in figure 10 . 
Scenario 7. Modified 1964 event: Kodiak asperity of the JDM

This event is a hypothetical earthquake that ruptures eight subfaults in the Kodiak asperity from the deformation model by Johnson and others (1996). Vertical coseismic deformations for this scenario are shown in figure 10.

Scenario 8. Modified 1964 event: Prince William Sound asperity of the SDM

This event is a hypothetical earthquake that ruptures the Prince William Sound asperity from the deformation model by Suito and Freymueller (2009). Vertical coseismic deformations for this scenario are shown in figure 10.

Scenario 9. Modified 1964 event: Kodiak asperity of the SDM

This event is a hypothetical earthquake that ruptures the Kodiak asperity from the deformation model by Suito and Freymueller (2009). Vertical coseismic deformations for this scenario are shown in figure 10.

\section{LANDSLIDE TSUNAMI SOURCES}

\section{Multiple submarine slope failures in Passage Canal during the 1964 earthquake}

A description and analysis of the damage resulting from waves generated by submarine landslide at the port of Whittier during the 1964 earthquake is provided in Kachadoorian (1965). The report also presents convincing evidence that massive submarine landslides were triggered by the earthquake. Pre- and post-earthquake bathymetric data and sub-bottom profiles of the western part of Passage Canal are shown in figure 11. The landslides in the western part of Passage Canal occurred on slopes ranging from 20 degrees offshore of the airstrip to 31 degrees at the marginal wharf. The largest change in the submarine slope was produced by the airstrip landslide. Unfortunately, there is currently no additional information as to whether or where the landslides occurred in the central and eastern parts of Passage Canal.

On the basis of pre- and post-earthquake bathymetry profiles, we approximate an initial distribution of the slide as follows. We digitized the pre- and post-earthquake bathymetry along $\mathrm{A}-\mathrm{A}^{\prime}, \mathrm{B}-\mathrm{B}^{\prime}$, and $\mathrm{C}-\mathrm{C}^{\prime}$ profile lines, shown by solid line segments in figure 11 . The digitized pre- and post-earthquake bathymetry along these profiles is shown in figure 12, by lines with hollow square and circle symbols, respectively. We also plot the present-day bathymetry along the profiles in figure 12 by a line marked with solid circles. Note that for the sake of validating simulations of the events of 1964, we edited ${ }^{6}$ the DEM to remove post-earthquake constructions such as the breakwater, the cruise ship terminal, and some parts of the small boat harbor. The edited DEM is shown in figure 13. The comparison of the post-earthquake bathymetry to the present-day depth contours along the shown profiles reveals that there are several discrepancies between the two profiles. The differences can be explained by digitizing, surveying, and measuring errors. Nevertheless, the present-day bathymetry profiles quantitatively match the post-earthquake profiles in the area of landslide.

We digitally add some material above the present-day bathymetry to match the pre-earthquake $\mathrm{A}-\mathrm{A}^{\prime}, \mathrm{B}-\mathrm{B}^{\prime}$, and $\mathrm{C}-\mathrm{C}^{\prime}$ profiles. The modeled landslide thicknesses are shown in figure 12 by lines marked with solid triangles. Figure 14a shows locations and thicknesses of three complexes: the Harbor, Airport, and Glacier (HAG) landslides. The Harbor and Airport landslide profiles fit the pre-earthquake bathymetry profiles, while there is little or no constraint on the Glacier landslide, whose existence is clearly marked in figure 11 . We assume that the pre-earthquake bathymetry in the region occupied by the Glacier landslide had the same slope as the preearthquake bathymetry in the location of the Harbor and Airport landslides. Additionally, we assume that the volume of the Glacier landslide is half the volume of the Airport landslide. Based on these assumptions, we estimate that the total volume of these landslides is about 15 million $\mathrm{m}^{3}$. After conducting several numerical experiments we conclude that the Airport landslide was a major contributor to the tsunami waves at the Whittier waterfront.

Scenario 10. Repeat of the 1964 event: Major underwater slide complexes of the 1964 earthquake-Harbor, Airport, and Glacier (HAG) landslides.

Figure 14a shows three slide complexes in the upper bay that were the major contributors to the locally generated waves that inundated the city of Whittier. The initial landslide thicknesses are approximated from the bathymetric difference profiles. The total volume for these slide complexes is approximately 15 million $\mathrm{m}^{3}$.

\section{Hypothetical landslide tsunami sources}

Kachadoorian (1965) provides a description of landslides at the head of Passage Canal during the 1964 event and hypothesizes regarding a landslide offshore of Billings Creek delta. Kachadoorian (1965) also mentions that the waves that struck the west coastline of Passage Canal originated along the north coastline of the canal and traveled southwest. Consequently, we consider another possible landslide location on the northern shore of Passage Canal. Unfortunately, there is no bathymetry

${ }^{6}$ For calculating inundation of potential tsunamis, the unedited DEM is used. 


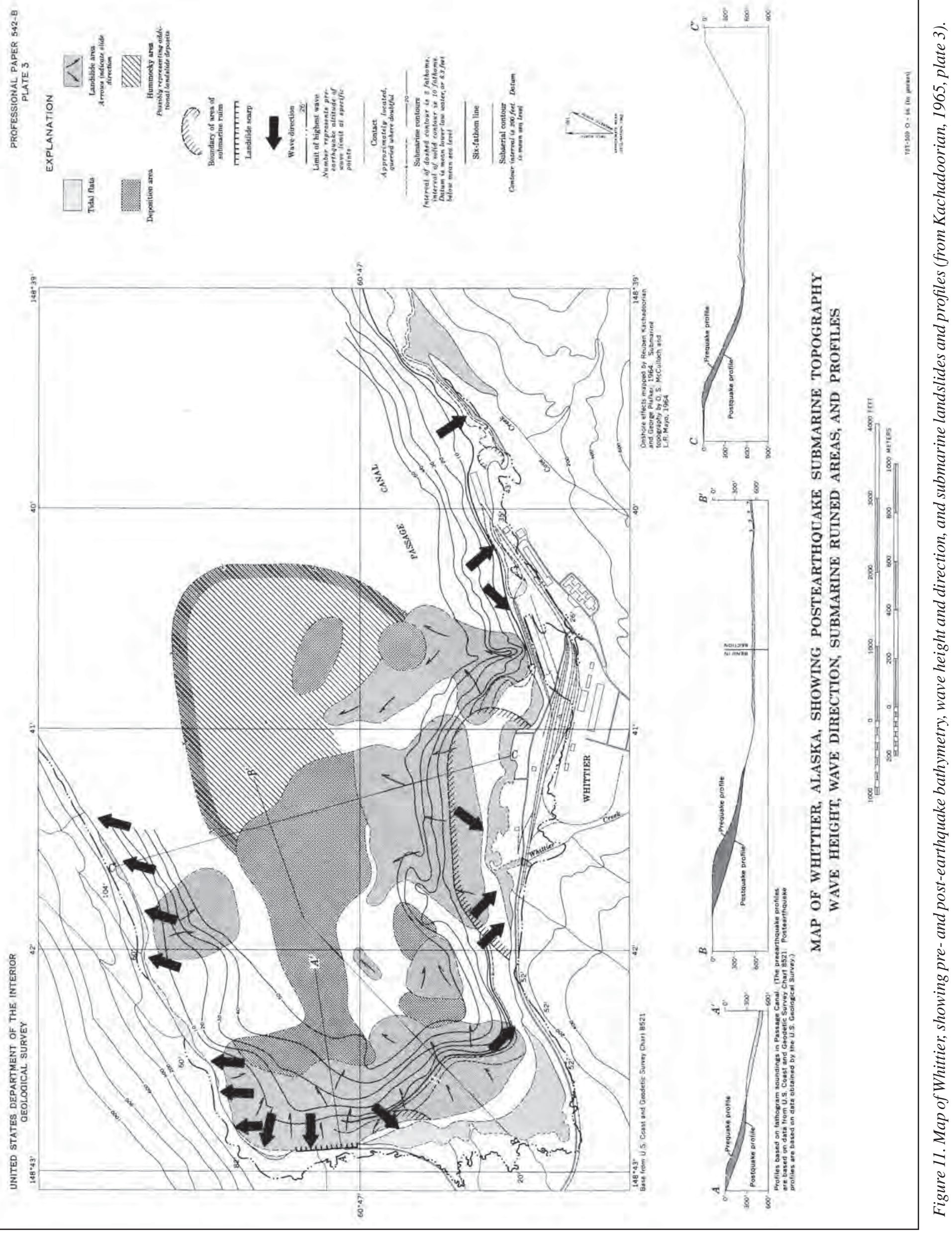




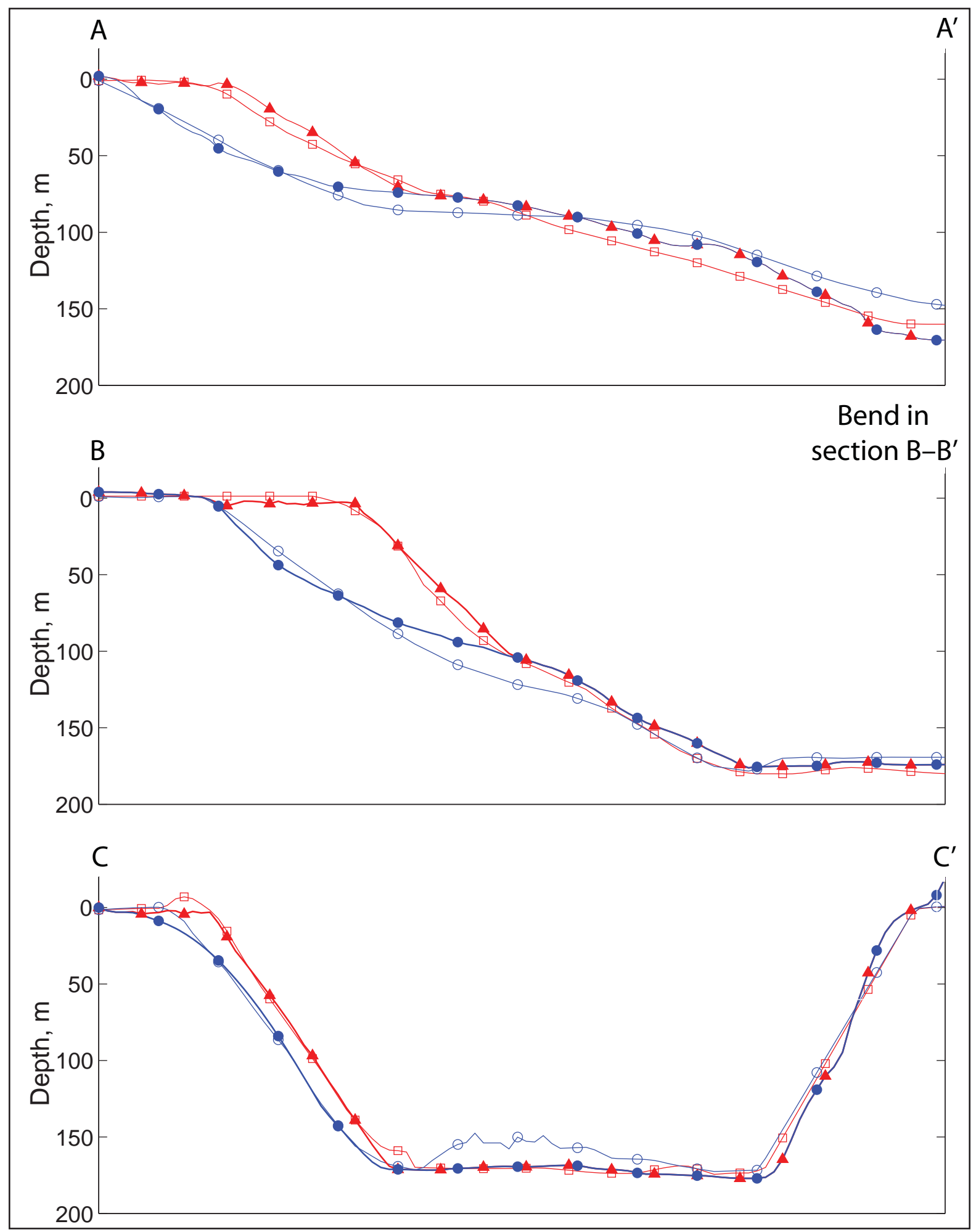

Figure 12. Pre- and post-earthquake bathymetry profiles along cross-sections $A-A$ ', $B$ to bend in section $B-B$ ', and $C-C$ ', shown in figure 11. The profiles are adopted from figure 11 and are supplemented with present-day bathymetry and modeled 1964 slide profiles. The present-day bathymetry profiles are shown by blue lines with solid blue circles. The modeled pre-1964 bathymetry profiles are shown by red lines with solid red triangles. The vertical scale is exaggerated. 


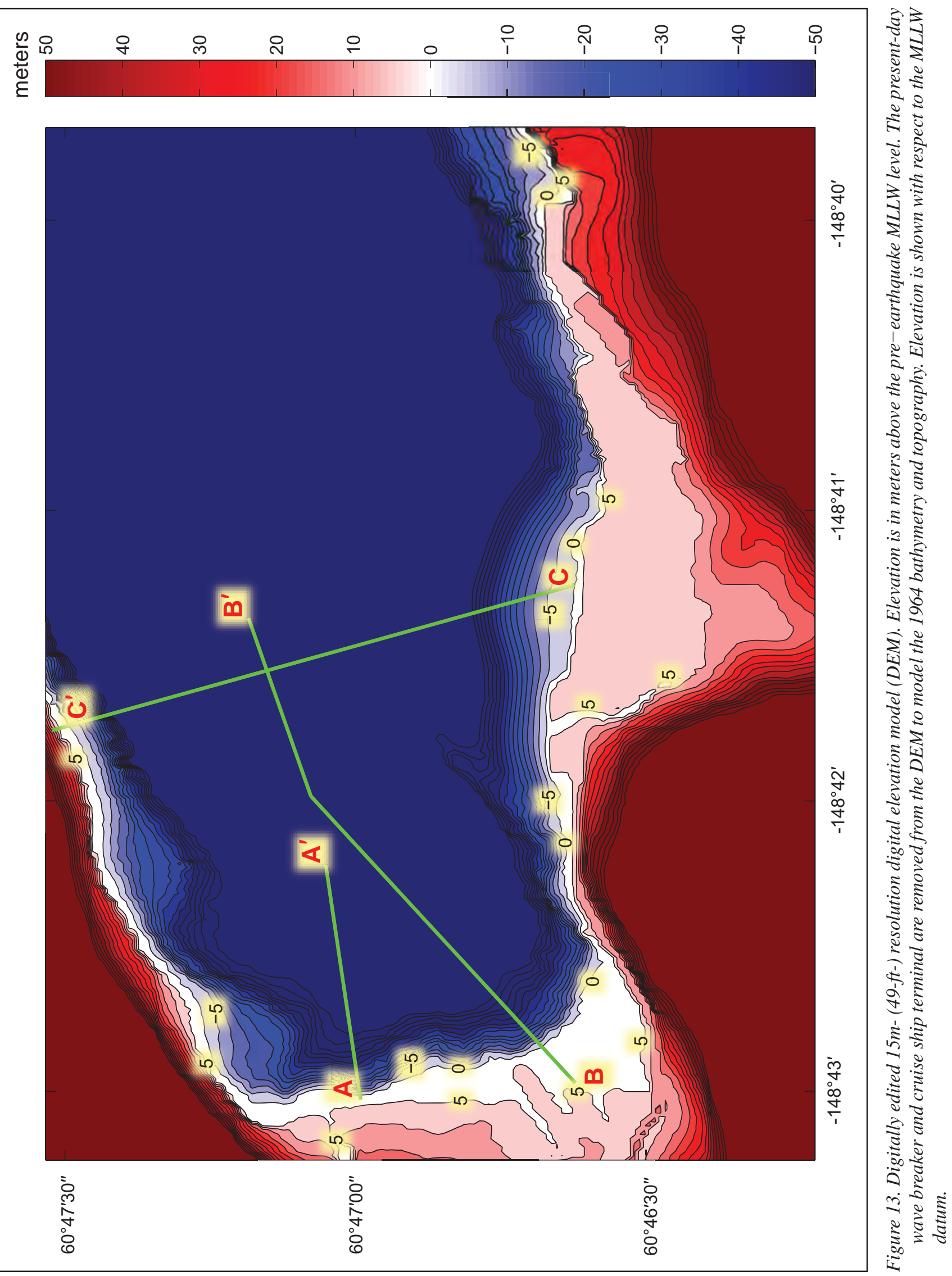


data to adequately constrain locations and thicknesses of underwater slides anywhere in Passage Canal, except at its head.

Scenario 11. Hypothetical event: Major underwater slide complex offshore of the northern shore of Passage Canal.

We assume that the failure surfaces correspond to the post-earthquake bottom of Passage Canal. The total volume of sediments is approximately 10 million $\mathrm{m}^{3}$. The slide thickness and location are shown in figure 14b.

Scenario 12. Hypothetical event: Major underwater slide complex offshore of the Billings Creek delta.

We assume that the failure surfaces correspond to the post-earthquake bottom of Passage Canal. The total volume of sediments is approximately 10 million $\mathrm{m}^{3}$. The slide thickness and location are shown in figure 14b.

Scenario 13. Hypothetical event: Simultaneous failure of underwater slide complexes described by scenarios $10-12$.

We assume that the slide-prone unconsolidated deposits described by scenarios 10-12 are initially at rest, then are simultaneously triggered into sliding by ground shaking, and move thereafter only under the force of gravity. The total volume of sediments is approximately 35 million $\mathrm{m}^{3}$.

\section{MODELING RESULTS}

\section{NUMERICAL MODELING OF THE 1964 TSUNAMI IN PASSAGE CANAL: MODEL VERIFICATION}

In this section, we compare inundation modeling results of the 1964 tsunami in Passage Canal with observations - the limit of highest wave and wave directions shown in figure 11 . To model inundation of coastal areas, we use a series of nested grids. Recall that the lowest resolution 2-arc-minute grid spans the Gulf of Alaska, while the finest resolution $15 \mathrm{~m}$ (49.2 ft) grid covers Passage Canal. We note again that the high-resolution DEM is digitally edited to remove post-1964 construction such as the cruise ship terminal and harbor. At the time of the

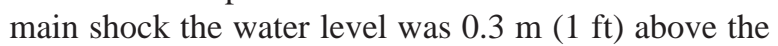
MLLW (Kachadoorian, 1965). A sketch of the water level in Passage Canal just before the earthquake is shown in figure 15a. During the earthquake, the Whittier area subsided by $\mathrm{S} \approx 1.6 \mathrm{~m}(5.3 \mathrm{ft})$. Unfortunately, it is not known when the subsidence occurred chronologically- before, during, or after the landslide-generated tsunami. In this report, we assume that the subsidence occurred within a few seconds after the main shock. A sketch of the Whittier harbor and landslide-generated tsunami during the earthquake is shown in figure $15 \mathrm{~b}$. To reconstruct the sea level at Whittier after the earthquake but before arrival of the tectonic tsunami, we first convert the edited DEM from the post-earthquake MHHW datum to the pre-earthquake MHHW datum by adding the subsidence $S$, figure 15 c. Then the sea level in the adjusted DEM is set to $0.3 \mathrm{~m}(1 \mathrm{ft})$ positive offset from the MLLW level ${ }^{7}$ in the adjusted DEM.

Although the residents of Whittier did not notice the tectonic tsunami wave, we model its impact on the city infrastructure. The source of local waves in Passage Canal ceased shortly after the end of ground shaking, so we can assume that the landslide-generated and tectonic tsunamis can be considered independent events, and hence modeled separately.

The first observed "glassy hump" of water during the earthquake (Wilson and Tørum, 1968) is attributed to a seiche wave generated by the $8.3 \mathrm{~m}(27 \mathrm{ft})$ horizontal translation of the entire area transverse to Passage Canal. We refer to Wilson and Tørum (1968), in which quantitative estimates of this seiche wave have been derived. Shortly after subsidence of the glassy hump of water, the second muddy bore of water inundated the downtown area of Whittier. The second wave has been attributed to the landslide-generated tsunami and is modeled in this report.

We assume that the slide-prone unconsolidated deposits are initially at rest and are triggered into sliding by ground shaking. The slide material moves thereafter only under the force of gravity. Shannon and Hilts (1973) conducted a subsurface geotechnical investigation of materials that failed in settings similar to Resurrection Bay, Alaska, during the 1964 earthquake, finding that the density of the slide material ranged from $2,000 \mathrm{~kg} / \mathrm{m}^{3}$ to $2,110 \mathrm{~kg} / \mathrm{m}^{3}\left(125 \mathrm{lb} / \mathrm{ft}^{3}\right.$ to $\left.132 \mathrm{lb} / \mathrm{ft}^{3}\right)$. Unfortunately, there are no measurements of the slide viscosity, but sensitivity studies by Rabinovich and others (2003) demonstrate that the influence of kinematic viscosity on tsunami wave heights is not significant. We assume slide density of $\rho=2,000 \mathrm{~kg} / \mathrm{m}^{3}\left(125 \mathrm{lb} / \mathrm{ft}^{3}\right)$ and slide kinematic viscosity of $\mu=0.05 \mathrm{~m}^{2} / \mathrm{s}\left(0.54 \mathrm{ft}^{2} / \mathrm{s}\right)$. The slide thickness is shown in figure 14. At the open boundary of the numerical grid, we specify the radiation boundary condition for the water waves. We numerically model triggering of landslide and simulate the landslide-generated tsunami waves in Passage Canal for 5 minutes with the 0.01 second time step.

${ }^{7}$ The tidal range at Whittier is $3.7 \mathrm{~m}(12.1 \mathrm{ft})$ from MHHW to MLLW. We note that currently MLLW is1.99 $\mathrm{m}$ (6.52 ft) below MSL as opposed to $1.92 \mathrm{~m}$ (6.3 ft) in 1964, when Kachadoorian reported it. In this work the change in the MLLW datum as well as the post-seismic rebound in Whittier were assumed to be negligibly small. 


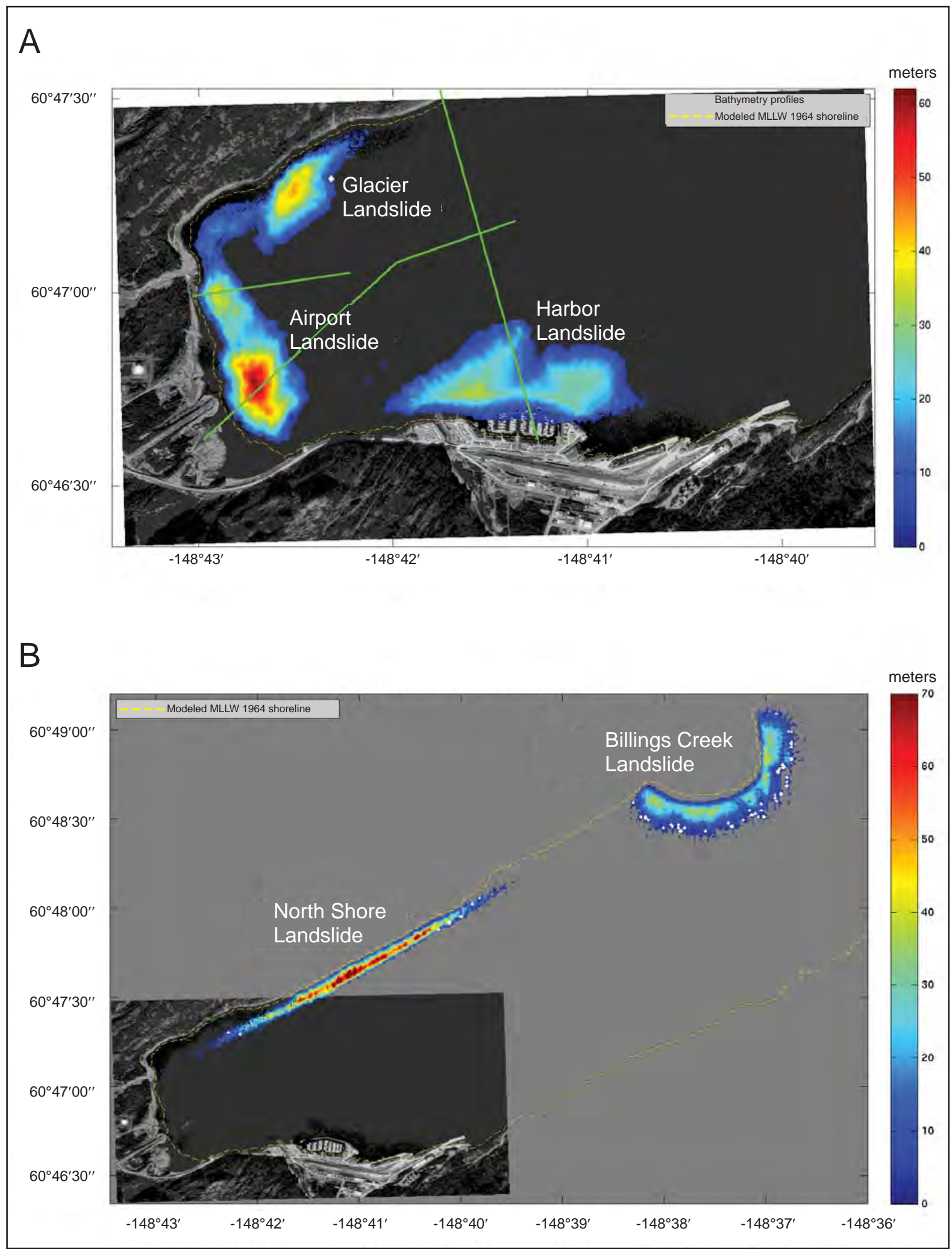

Figure 14. Illustrations showing initial thickness of landslides. (A) Harbor-Airport-Glacier (HAG) landslide complex, with a volume of 15 million $\mathrm{m}^{3}$ (530 million $\mathrm{ft}^{3}$ ). (B) Locations and thicknesses of the north shore and Billings Creek landslides. The volume of each landslide is 10 million $\mathrm{m}^{3}$ (350 million $\mathrm{ft}^{3}$ ). The locations of bathymetry profiles used to constrain the HAG landslide are shown by green lines (A); simulated pre-earthquake $M L L W$ shoreline is shown by a dashed yellow line (B). 


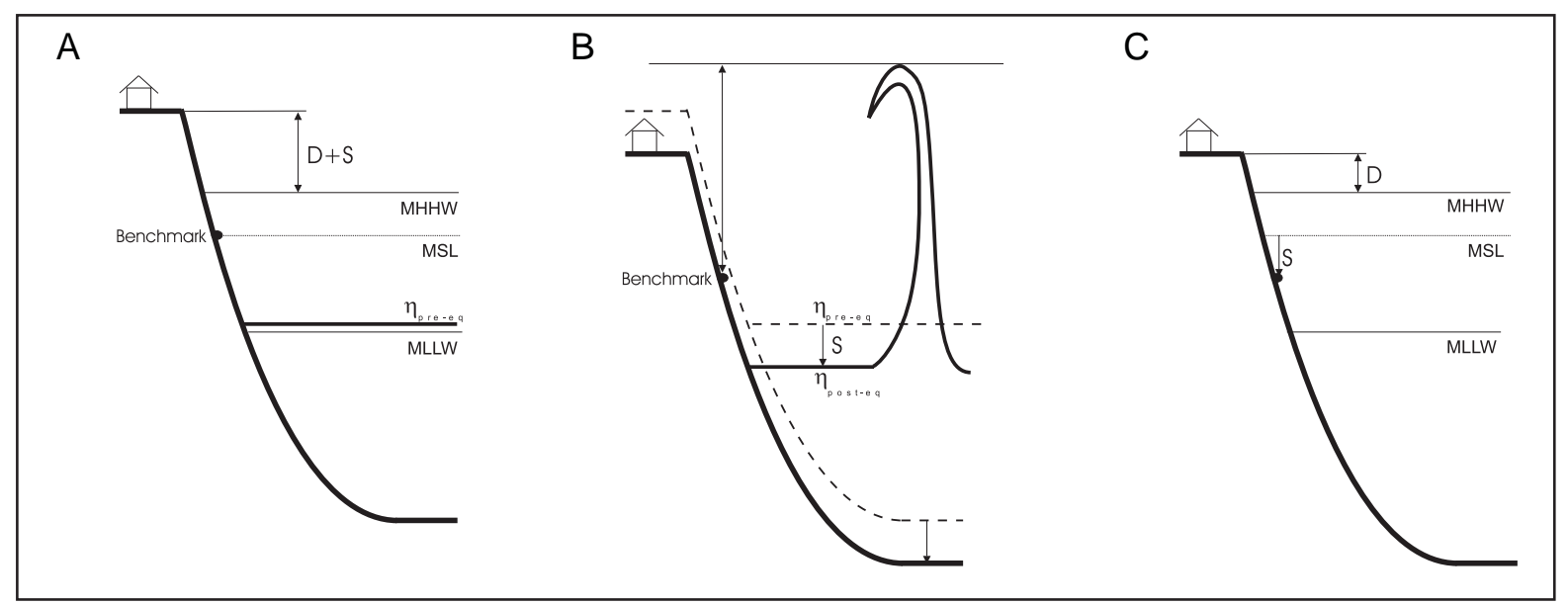

Figure 15. Schematic drawings of the city harbor before the earthquake (A), after the earthquake and during the landslide-generated tsunami (B), and at the present (C). $S$ is the coseismic subsidence; $D$ is the elevation of harbor parking with respect to the MHHW; $\eta$ is the water level.

Figure 16a shows modeled inundation by tsunami waves that are generated by ground failures according to scenarios 10-13. The observed extent of inundation after the 1964 earthquake is shown by the solid yellow line. Before analyzing the modeling results, we emphasize an interesting fact: There was no observed inundation behind the reinforced concrete building of the railroad depot (marked by a red rectangle with black border) during the 1964 event. This fact reveals that a tsunami wave that hit the depot was traveling in a southwest direction. We recall that Kachadoorian (1965) also mentions that the waves originated along the north coastline of the canal and traveled in a southwest direction. Unfortunately, the current version of the DEM lacks the railroad building (demolished in 2002), and hence the modeled runup should significantly extend inland and "fill the gap" behind it.

In figure 16, the modeling results show a directional pattern of inundation corresponding to each landslidegenerated tsunami. The HAG slide-generated tsunami causes significant inundation (blue line) at the head of Passage Canal and the western side of the Whittier downtown, whereas the inundation by north shore landslide-generated tsunami (green line) is localized at the eastern part of the town, particularly near the railroad depot. Note that the energy of the Billings Creek landslide-generated tsunami is primarily directed toward the south coast and quickly dissipates in the direction of the harbor area. Therefore this landslide-generated tsunami causes an insignificant inundation (light blue line) beyond the coastline (dashed yellow line) at the time of the 1964 earthquake.

Taking into account that the HAG landslide configuration is roughly approximated by the bathymetry difference profiles, the modeling results show a good comparison with observations in the western part of downtown. The tsunami triggered by the north shore landslide models the observed southwest-traveling wave and inundates an area behind the depot; however, the modeled inundation extent is less than the observed one. Consequently, we model scenario 13 and simulate tsunami waves in the case of all landslides failing simultaneously. Although it is possible that individual slides were triggered at different times during or after the ground shaking, there is neither evidence to support nor to reject this hypothesis.

In scenario 13, we assume that all slides are initially at rest and are simultaneously triggered into motion by ground shaking. The resultant modeled inundation (red line) significantly extends inland, particularly within the downtown area. The discrepancy between the modeled and observed inundation in the western part of Whittier can be explained by the presence of a significant flat area in the present DEM (the topography was altered by the addition of the parking lot, which was constructed after the 1964 event), where the waves triggered by the HAG and north slides arrive at the same time and collide with each other. Note that a small temporal delay in landslide failures can change arrival time of these waves and hence significantly modify their non-linear interference. Unfortunately, the timing of future landslide failure is unknown and additional research in this area is necessary.

Figure 16b shows that the model captures an extreme runup at the northern shore of Passage Canal. The highest modeled value of runup at the northern shore is about $24 \mathrm{~m} \mathrm{(79} \mathrm{ft)} \mathrm{above} \mathrm{the} \mathrm{pre-earthquake} \mathrm{MSL,} \mathrm{when} \mathrm{ap-}$ proximately $31.7 \mathrm{~m}$ (104 ft) above sea level inundation was reported after the 1964 event. The highest wave in Whittier was observed at the small boat harbor (point 5, figure A-2), northeast of the railroad depot, where the wave reached $13.1 \mathrm{~m}(43 \mathrm{ft})$. At the railroad depot itself, 


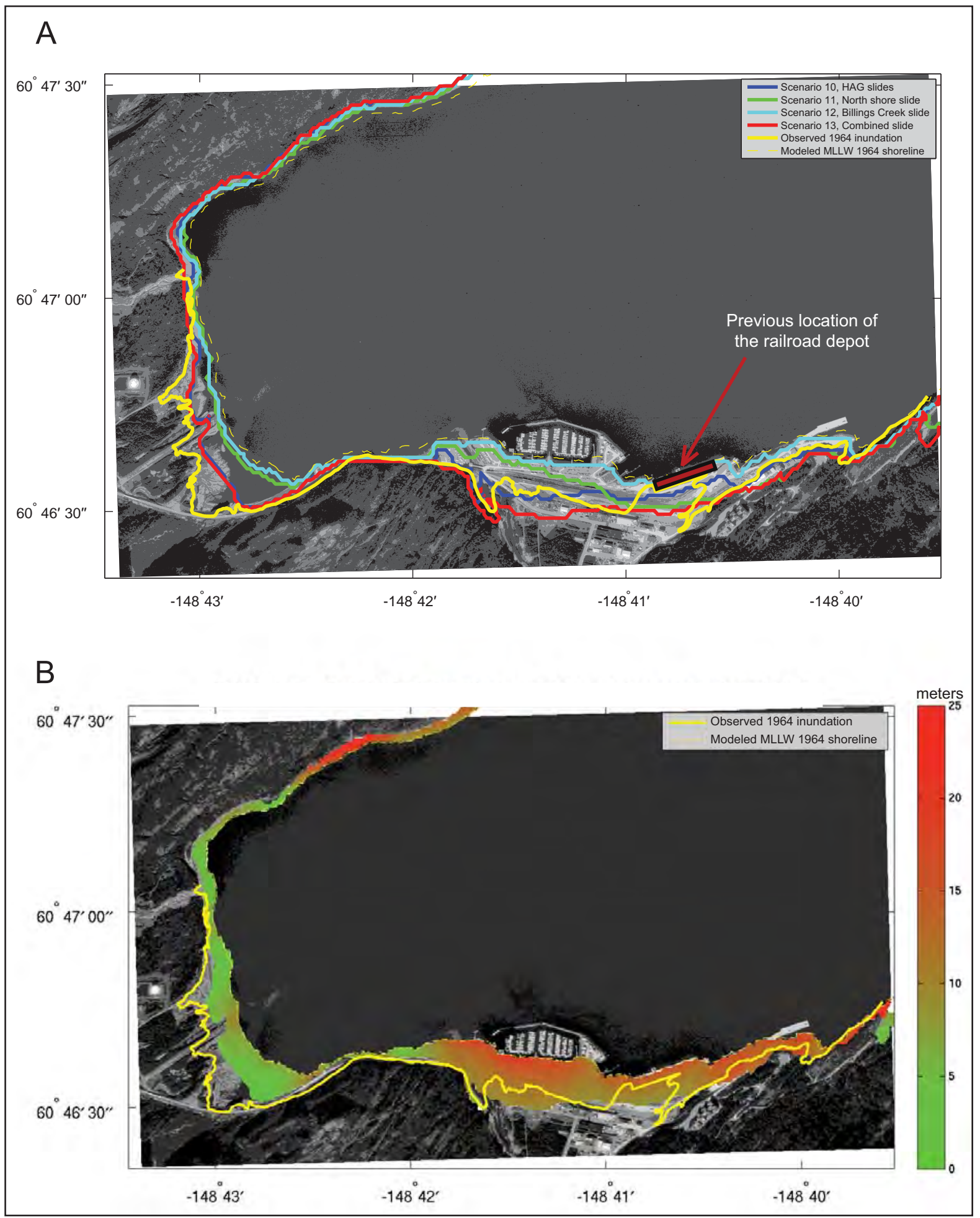

Figure 16. Maximum computed runup caused by landslide-generated tsunami waves in Passage Canal during the 1964 event. (A) Modeled inundation lines for scenarios 10-13. (B) Maximum modeled runup heights within the inundation zone for Scenario 13. Runup height is in meters above the pre-earthquake MLLW datum. The yellow line represents observed inundation caused by the 1964 tsunami. The modeled MLLW shoreline before the earthquake is shown by a dashed yellow line. 
according to eyewitnesses, the wave was about $12.2 \mathrm{~m}$ (40 ft) high. Figure 17 shows water level dynamics at several locations along the Whittier waterfront. We note that the model captures well the observed wave heights at the eastern part of Whittier (points 2 and 5, figure A-2), however, the modeled extent of inundation is farther inland than the observed extent along Depot Road. At the location of the completely destroyed Columbia Lumber Co. (point 6, figure A-2) on the right bank of Whittier Creek, the modeled wave reached an altitude of $9 \mathrm{~m}$ (29 $\mathrm{ft}$ ) above ground, sufficient to totally disintegrate industrial buildings and scatter debris as shown in the aerial photography after the 1964 event (Kachadoorian, 1965).

Although the model captures the south-southwesttraveling waves that struck the southern shore of Passage Canal about 1,300 m (4,270 ft) west of Whittier Creek with tremendous force (Kachadoorian, 1965), the height of the modeled wave seems to be underpredicted. The reported runup in this area was approximately $15 \mathrm{~m}$ (49 $\mathrm{ft}$ ), whereas the numerically modeled runup is about 7 $\mathrm{m}(23 \mathrm{ft})$. The disparity between modeling results and observation reveal the likelihood that multiple landslides occurred at the northern shore of Passage Canal; however, without adequate bathymetry it is difficult to constrain their locations and thicknesses.
Preliminary computations show that it takes approximately 60 minutes for tsunami waves generated in the Gulf of Alaska outside of Prince William Sound to travel into the Whittier harbor. The 1964 earthquake occurred at 5:30 p.m. local time in Whittier when tides

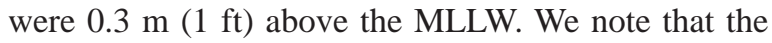
difference between the MHHW and MLLW in Whittier

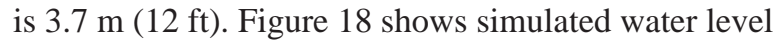
dynamics in the Whittier harbor and suggests that the maximum height of the waves that hit Whittier was about $3.5 \mathrm{~m}(11.5 \mathrm{ft})$ at the MLW tide, if the local $1.6 \mathrm{~m}$ (5.3 ft) subsidence is taken into account. Note that this wave height is within the tidal range for the community and does not produce flooding since the harbor parking lot elevation is approximately 2-3 m (6.6-9.8 ft) above the MHHW water level. The computed inundations by tsunami waves generated by the JDM, SDM, and landslides as well as the observed 1964 inundation zone in Whittier are shown in figure 19. The dashed yellow line represents $0 \mathrm{~m}(0 \mathrm{ft})$ elevation with respect to the sea level in Whittier at the time of the earthquake. The modeled inundation by JDM and SDM almost coincide with the shoreline, except for low-lying areas at the head of Passage Canal. This explains why the residents of Whittier did not observe the arrival of tectonic waves after the earthquake.

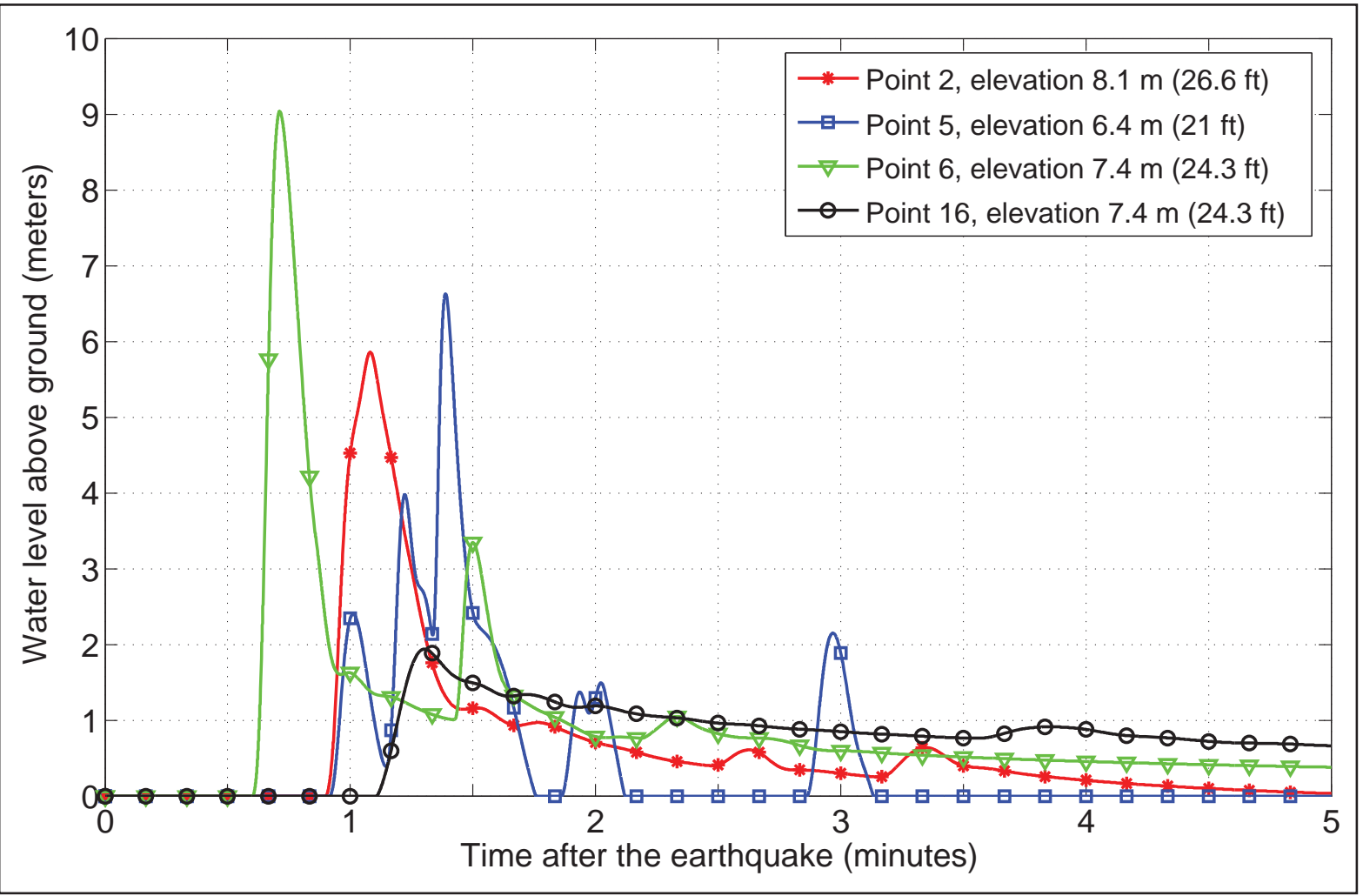

Figure 17. Modeled water level dynamics of landslide-generated waves at certain locations near the Whittier waterfront. Locations of points 2, 5, 6, and 16 are shown in figure A-1. 


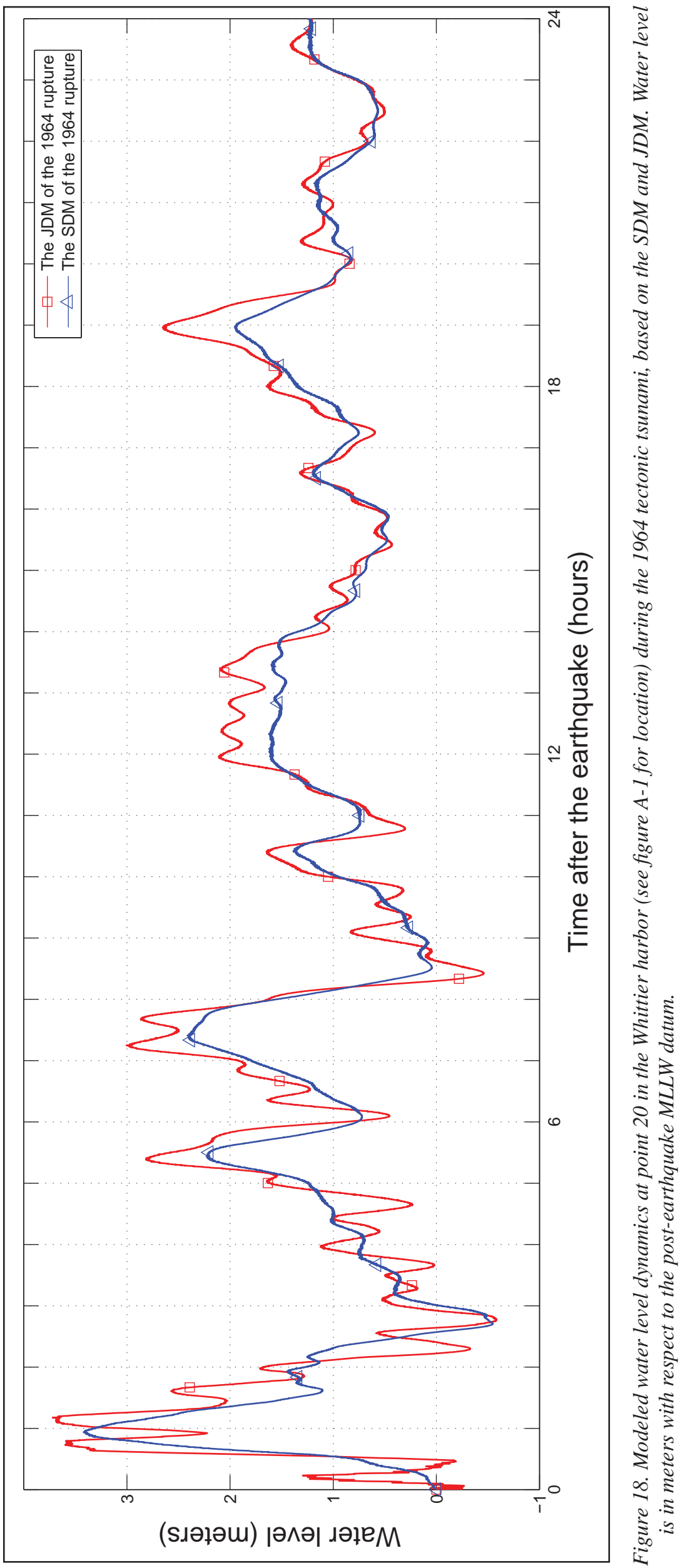




\section{RESULTS OF HYPOTHETICAL TSUNAMI SCENARIOS}

We performed numerical calculations for all the above-mentioned scenarios. For scenarios that describe tectonic tsunamis, we modeled the water dynamics in each grid (listed in table 1) and computed the extent of inundation only in the high-resolution grid. For scenarios related to the landslide-generated tsunamis, we simulate the water dynamics and only in the high resolution grid and compute the runup therein.

We begin discussion of our modeling results by noting that a potential rupture of the Yakataga segment predicts subsidence of the ocean bottom in the Prince William Sound (PWS) area, while the Johnson and Suito deformation models (JDM and SDM; scenarios 1 and 2 , respectively) suggest an uplift in this region. For the sake of brevity, we consider only the JDM rupture. The vertical displacement of the multi-segment JDM rupture (scenario 3) in the PWS region is less than that produced by the JDM rupture (scenario1). Since the leading wave arrives at Passage Canal from the PWS region, the height of the leading wave caused by the multi-segment JDM rupture is less than that due to the JDM rupture. In figure 20a, we show the computed sea level dynamics inside the Whittier harbor for the JDM (scenario 1) and the multi-segment JDM rupture (scenario 3). Note that the modeled tectonic tsunami generated in scenario

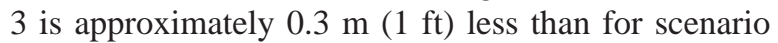
1 , even though the rupture in scenario 3 models a far greater earthquake. The wave from the rupturing YY segment arrives approximately 2 hours after the onset of the earthquake and generates additional oscillations on top of the already existing tsunami. These oscillations superimpose and produce a large wave 7 hours after the earthquake, shown by an arrow in figure 20a. Note that the modeled inundations in scenarios 1 and 3 are significantly different within the city of Whittier. Although the difference in the modeled wave height is relatively small, the computed inundation area is different due to ground leveling, developing the parking lot, and the non-linear nature of the runup. Figure 20b shows computed inundation zones for tsunami waves, generated by a potential rupture of the 1964 Great Alaska Earthquake (scenario 1) and its extension over the YY segment (scenario 3).

Analysis of tsunamis triggered by rupturing of the Kodiak Island (KI) asperity of the 1964 event reveals that the waves arriving at Whittier do not exceed $0.5 \mathrm{~m}$ (1.6 ft) height and can produce only a moderate inundation in low-lying areas. The comparison of numerical results, related to rupturing of the entire 1964 zone and its PWS asperity alone, shows that the modeled inundation zones are identical in Whittier, since the tsunami primarily arrives at Passage Canal from the PWS region. Finally, we compare potential inunda- tion by the landslide-generated tsunamis, for instance, scenarios $10-13$ in figure 21 . Scenario 13 produces the greatest inundation and can be considered one of the worst credible scenarios. Therefore, we only plot the following potential inundation zones in figure 22. The inundation zones related to scenario 1 (the JDM of the 1964 rupture), scenario 2 (the SDM of the 1964 rupture), scenario 5 (the Cascadia Zone rupture), and scenario 13 (failing of all potential landslides) are delineated by green, blue, light blue, and red lines, respectively. The observed 1964 inundation is shown by the solid yellow line, whereas the present-day shore (MHHW datum) is outlined by a dashed yellow line.

Figure 23 shows the maximum composite calculated extent of inundation for all 13 scenarios, and the maximum composite flow depths over dry land. Note that the tsunami flow depth is one of the important indicators of potential damage, and must be differentiated from runup height (Synolakis and Bernard, 2006). For easier visual reference, we indicate the values of $0.5 \mathrm{~m}(1.6 \mathrm{ft})$, which approximately corresponds to a knee height, and $2 \mathrm{~m}$ (6.6 ft), which is just above the average person's body height. In several areas in the western section of the tidal flats, the 1964 inundation limit extends beyond the maximum estimated inundation. We did not adjust the maximum calculated inundation extent in these areas to match the 1964 limit, because observations in this area are not particularly reliable.

\section{TIME SERIES AND OTHER NUMERICAL RESULTS}

To help emergency managers assess the tsunami hazard in Whittier, we supplement the inundation maps with the time series of the modeled water level and velocity dynamics at certain locations around Passage Canal. The locations are chosen and recommended (oral commun. with the city manager) both within the developed areas and offshore from a proposed subdivision in Shotgun Cove. For each location shown by a number in figure A-1 (A and B), we plot the sea level and water velocity in figures A-2 and A-3. The zero time corresponds to the epicenter origin time. Elevations of onshore locations correspond to the post-earthquake MHHW datum, while for offshore locations we use the pre-earthquake datum to show the height of arriving tsunami waves. The dashed lines show the water level after the tsunami. Since velocity magnitude is calculated as water flux divided by water depth, the velocity value can have large uncertainties if the water depth is small. In the plots provided, the velocity is computed only where the water depth is greater than $0.3 \mathrm{~m}(1 \mathrm{ft})$.

Analysis of the time series plot shows that the northern shore slide can create a devastating wave directed towards the eastern part of the city, (for example, points 1, 2, 4, and 5), while the potential HAG slides can also 


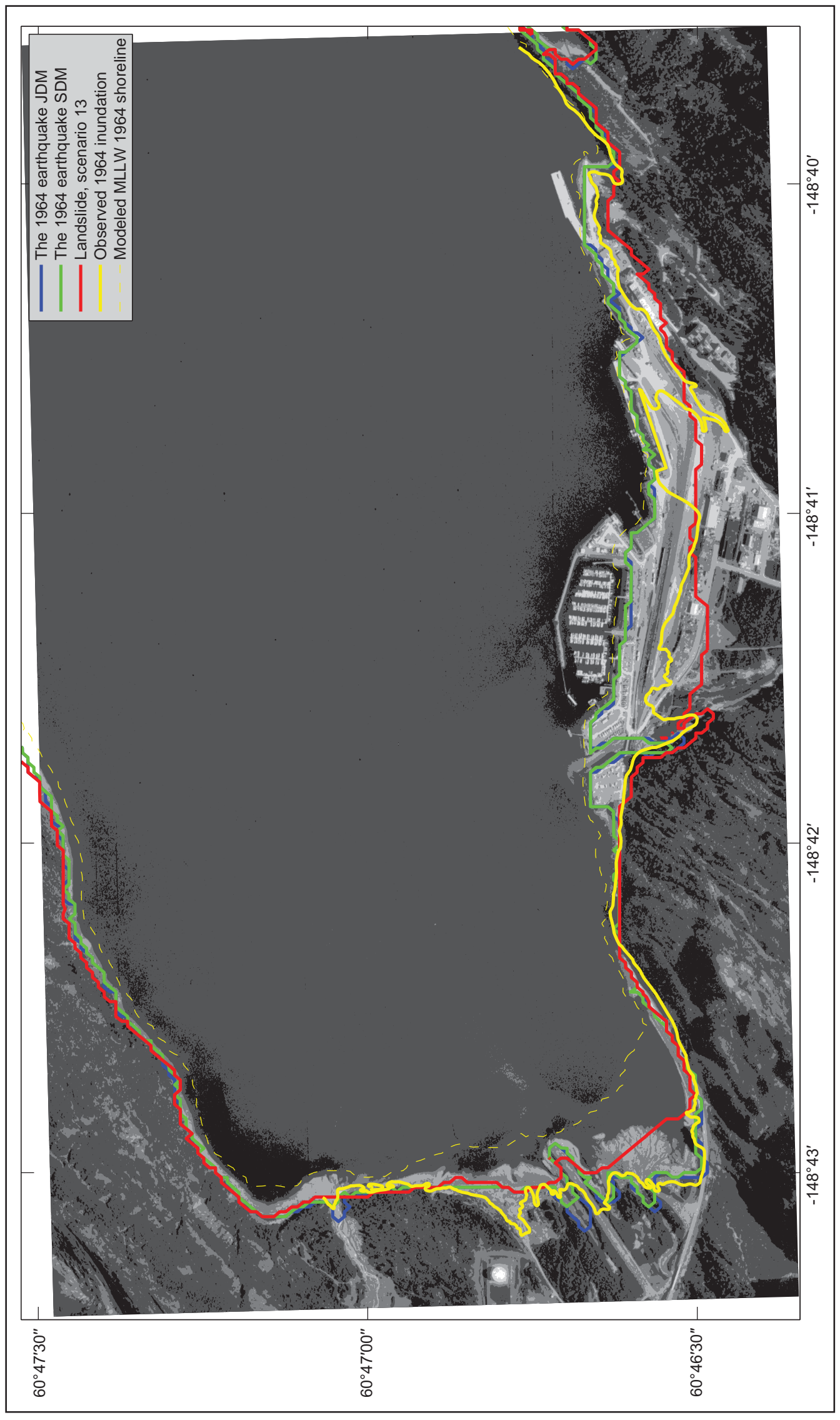

ई

¿

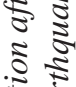

:

ミ

₹

క.

กิ

ऽ

है

हี

के

ำ क्षे

$\Xi$

效

3ำ

วิ ะ

है

is

एँ 3

उ워

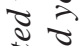

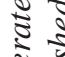

के

ธิن

ชิ

ธิ

든

ำ

ป

.

ปั

$\frac{10}{8}$

ते ई

ปี ฮै

ป

$\approx$

ㅎำ

.

षै 3

웍

촌

$\frac{8}{2}$

$\frac{8}{5}$

ह อ

ธี ह

है

峁

옳

$\rightarrow \div-$

ๆ

ฐ 
impact the western part of Whittier, (for example, points 6, 8, and 14). Note that points 3 and 15 are not inundated if the northern and HAG landslides fail separately, but are inundated if they fail together, as shown in figure 21. Unfortunately, it is impossible to determine the timing of potential failures, and it is recommended to consider that points 3 and 15 can be flooded. Although the Billings Creek slide produces a relatively small wave (for example, points 19 and 25), it can devastate the southern shore of Passage Canal. The numerical calculations show that the runup from this slide at certain areas near Shotgun Cove can reach up to $10 \mathrm{~m}$ (33 ft). Large uncertainties in the digital elevation model (DEM) east of Whittier, particularly along the shore of Shotgun Cove, impede development of inundation maps east of the Whittier downtown.

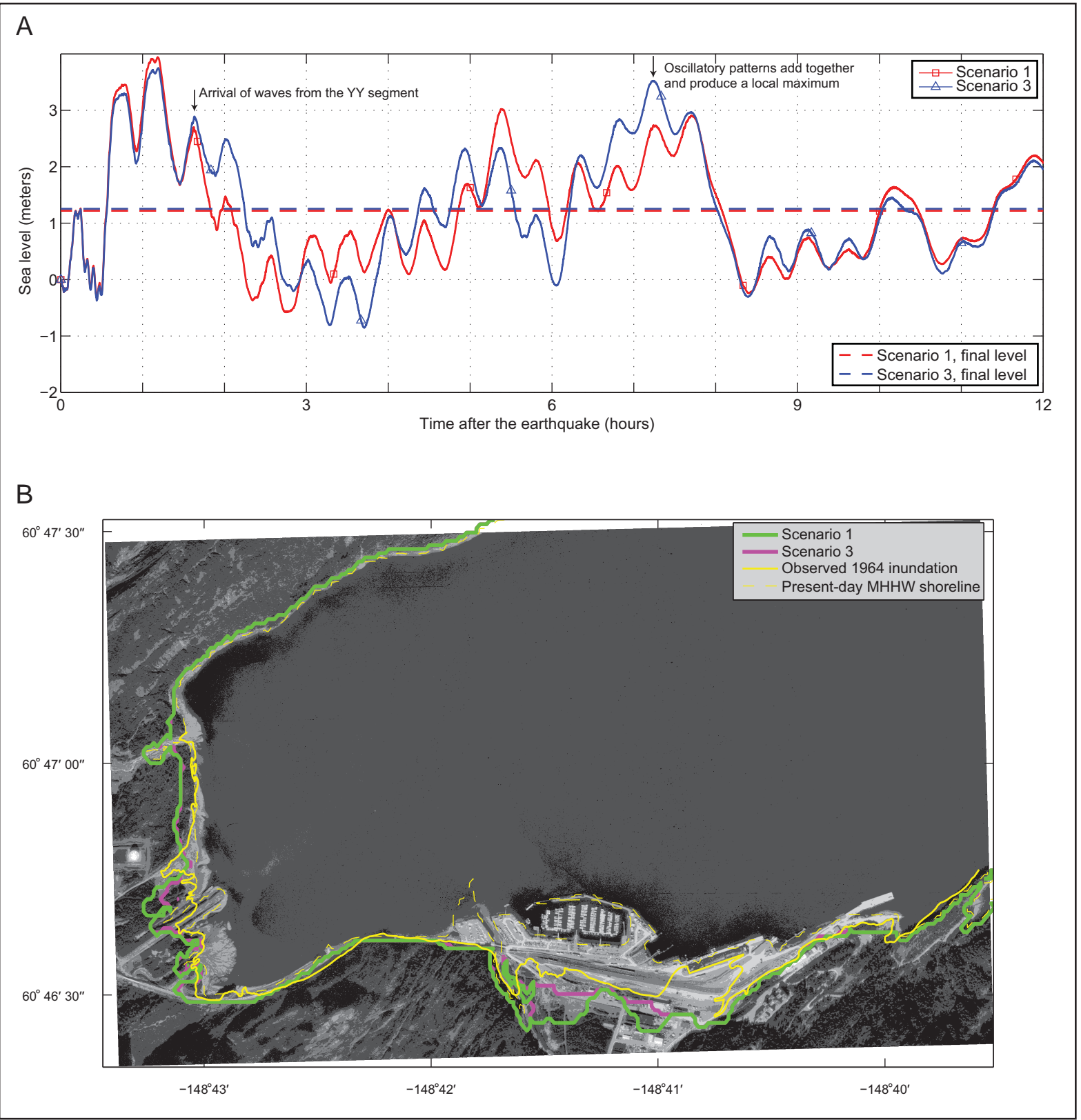

Figure 20. (A) Computed water level dynamics in the Whittier harbor, according to scenarios 1 and 3. The water level is plotted with respect to the sea level just prior to the earthquake, to show the height of tsunami wave crests. Arrival of the first wave from the rupturing YY segment and a local maximum of the water level are shown by arrows. The dashed lines (final level) show the water level after the tsunami passes. (B) Computed inundation areas, according to scenarios 1 and 3. 


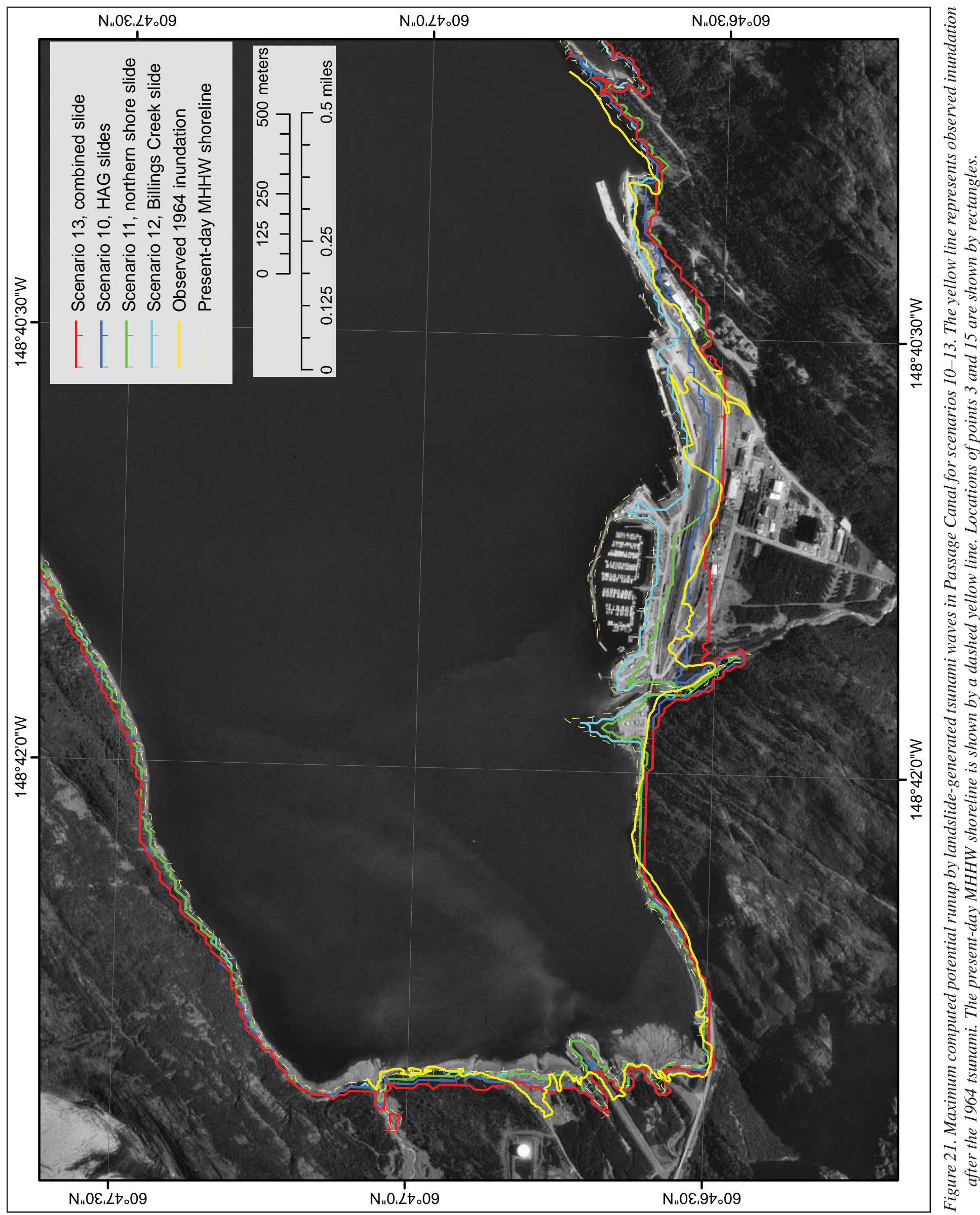




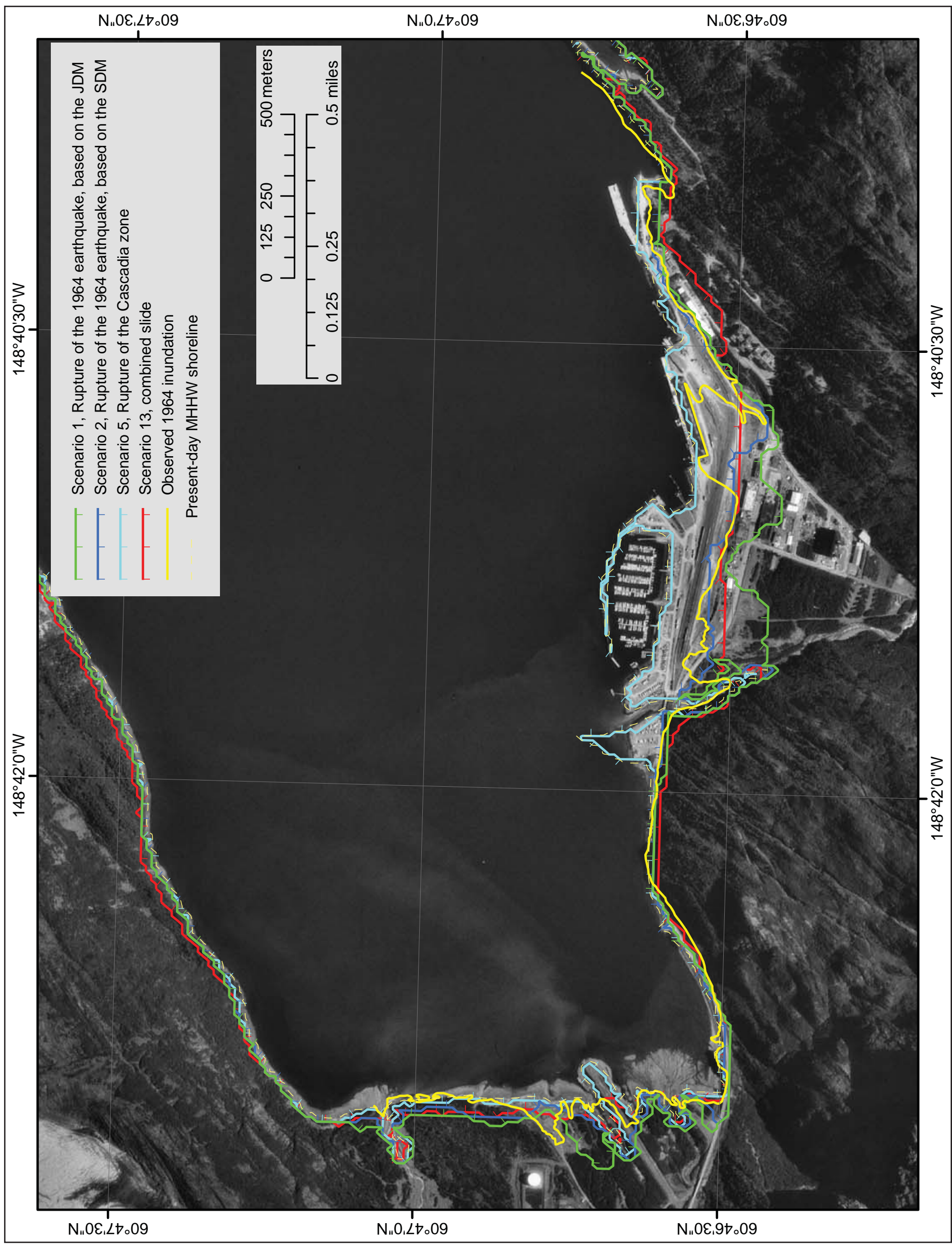




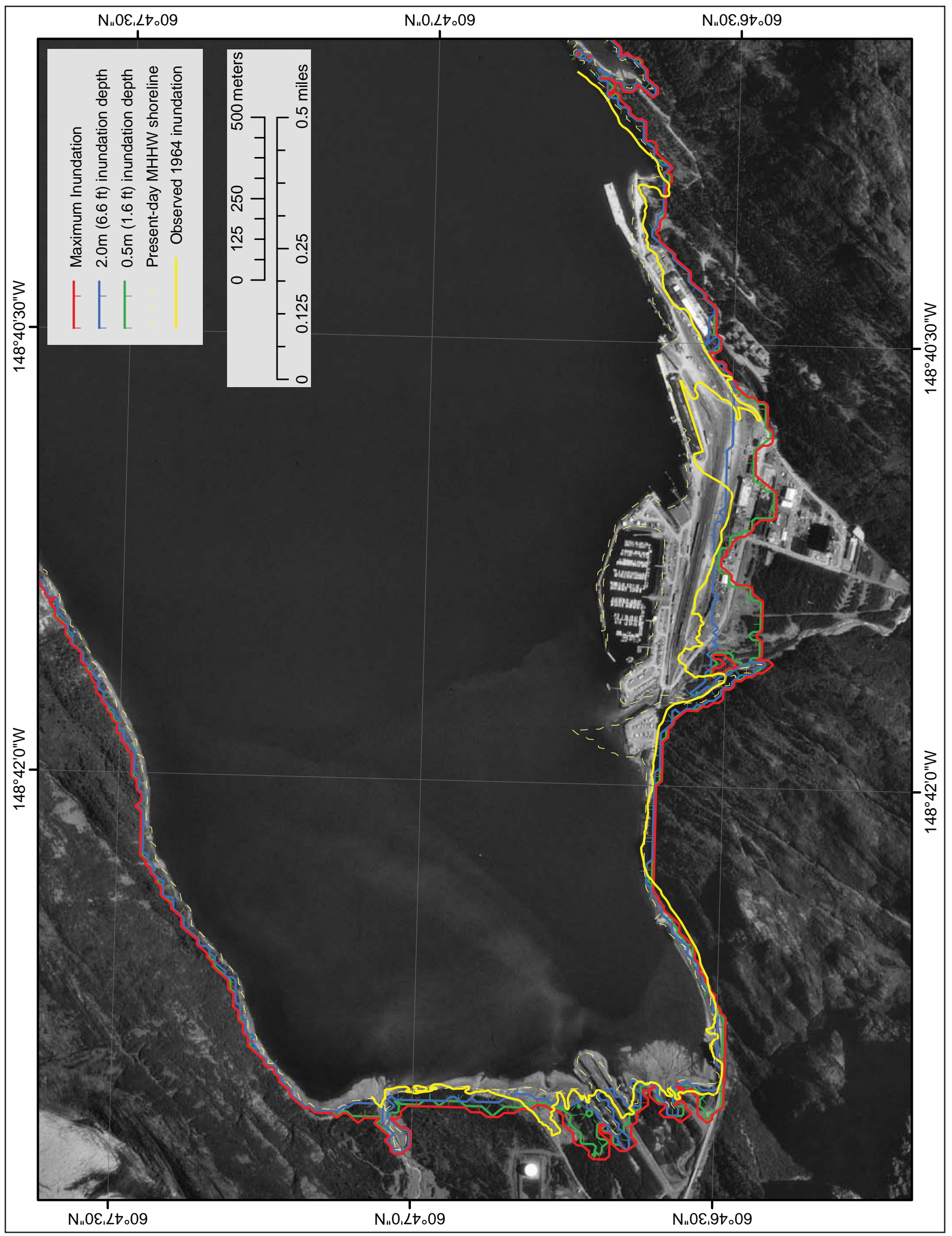




\section{SOURCES OF ERRORS AND UNCERTAINTIES}

The hydrodynamic model used to calculate tsunami propagation and runup is a nonlinear flux-formulated shallow water model (Nicolsky and others, 2011). It passed the validation tests required for models used in production of tsunami inundation maps (Synolakis and others, 2007).

The source mechanism remains the biggest unknown in the problem of tsunami modeling. Since the initial condition for the modeling is determined by the displacement of the ocean bottom, the largest source of errors is the earthquake model. When the tsunami is generated in the vicinity of the coast, the direction of the incoming waves, their amplitudes, and times of arrival are determined by the initial displacements of the ocean surface in the source area because the distance to the shore is too small for the waves to disperse. Therefore, the near-field inundation modeling results are especially sensitive to the fine structure of the tsunami source. The modeling process is highly sensitive to errors when the complexity of the source function is combined with its proximity to the coastal zone.

During development of the tsunami inundation maps, a spatially averaged ground subsidence is assumed for the entire city of Whittier. However, during a potential earthquake, soil compaction in areas of unconsolidated deposits in the coastal area might occur and an extent of the tsunami inundation could be farther landward. Finally we mention that the horizontal resolution of the

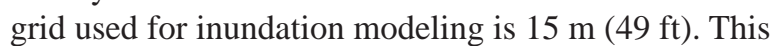
scale is limited by the resolution of the topographic and bathymetric data used for the grid construction. The 15 $\mathrm{m}(49 \mathrm{ft})$ resolution is high enough to describe major relief features, but small topographic features, buildings, and other facilities cannot be accurately resolved by the existing model.

\section{SUMMARY}

We present the results of numerical modeling of earthquake-generated tsunami waves for the Whittier area and western Passage Canal, Alaska. The maps showing the results of our modeling have been completed using the best information available, and are believed to be accurate, however, their preparation required many assumptions. We considered several tectonic and landslide scenarios and provide an estimate of maximum credible tsunami inundation. Actual conditions during a tsunami event may vary from those considered, so the accuracy cannot be guaranteed. The limits of inundation shown should be used only as a guideline for emergency planning and response action. Actual areas inundated will depend on specifics of the earth deformations, on land construction, and tide level, and they may differ from areas shown on the map. The information on this map is intended to permit state and local agencies to plan emergency evacuation and tsunami response actions in the event of a major tsunamigenic earthquake. These results are not intended for land-use regulation.

\section{ACKNOWLEDGMENTS}

This project was supported by the National Oceanic and Atmospheric Administration grants 27-014d and 06028a through Cooperative Institute for Arctic Research. Numerical calculations for this work were supported by a grant of High Performance Computing (HPC) resources from the Arctic Region Supercomputing Center (ARSC) at the University of Alaska Fairbanks as part of the U.S. Department of Defense High Performance Computing Modernization Program. Reviews by Dr. Timothy Walsh and Dr. Juan Horrillo improved the report and maps. We thank R. Grapenthin and B. Witte for their help with the RTK GPS survey in Whittier.

\section{REFERENCES CITED}

Alaska Division of Community Advocacy, 2005, Seward community overview: State of Alaska Community Database Online, http://www.commerce.state.ak.us/ $\mathrm{dca} / \mathrm{commdb} / \mathrm{CF}$ BLOCK.cfm.

Assier-Rzadkiewicz, S., Mariotti, C., and Heinrich, P., 1997, Numerical simulation of submarine landslides and their hydraulic effects: Journal of Waterway, Port, Coastal, and Ocean Engineering, v. 123, no. 4, p. 149-157.

Atwater, B.F., 1987, Evidence for great Holocene earthquakes along the outer coast of Washington State: Science, v. 236, p. 942-944.

Atwater, B.F., Musumi-Rokkaku, Satoku, Satake, Kenji, Tsuji, Yoshinobu, Ueda, Kazue, and Yamaguchi, D.K., 2005, The orphan tsunami of 1700-Japanese clues to a parent earthquake in North America: U.S. Geological Survey Professional Paper 1707 (prepared in cooperation with the Geological Survey of Japan, the University of Tokyo, and the University of Washington, and published in association with University of Washington Press), 133 p.

Bornhold, B.D., Thomson, R.E., Rabinovich, A.B., Kulikov, E.A., and Fine, I.V., 2001, Risk of landslidegenerated tsunamis for the coast of British Columbia and Alaska, in Mahmoud, M., van Everdingen, R., and Carss, J., eds., An earth odyssey-Proceedings of the 54th Canadian Geotechnical Society Conference: Richmond, B.C., Bitech Publishers, Ltd., p. $1,450-1,454$. 
Caldwell, R.J., Eakins, B.W., and Lim, E., 2009, Digital elevation models of Prince William Sound, Alaska-Procedures, Data Sources and Analysis: Boulder, Colorado, National Geophysical Data Center, NOAA, 43 p., www.ngdc.noaa.gov/dem/ report/download/1305.

Carver, G.A., and Plafker, George, 2008, Paleoseismicity and neotectonics of the Aleutian subduction zoneAn overview, in Freymueller, J.T., Haeussler, P.J., Wesson, R.L, and Ekström, G., eds., Active tectonics and seismic potential of Alaska: American Geophysical Union Geophysical Monograph 179, p. 43-63.

Christensen, D.H., and Beck, S.L., 1994, The rupture process and tectonic implications of the Great 1964 Prince William Sound Earthquake: Pure and Applied Geophysics, v. 142, no. 1, p. 29-53.

DeMets, Charles, Gordon, R.C., Argus, D.F., and Stein, Seth, 1990, Current plate motions: Geophysical Journal International, v. 101, no. 2, p. 425-478.

Doser, D.I., and Brown, W.A., 2001, A study of historic earthquakes of the Prince William Sound, Alaska, region: Bulletin of the Seismological Society of America, v. 91, no. 4, p. 842-857.

Fine, I.V., Rabinovich, A.B., Kulikov, E.A., Thomson, R.E., and Bornhold, B.D., 1998, Numerical modeling of landslide-generated tsunamis with application to the Skagway Harbor tsunami of November 3, 1994, in Proceedings, International Conference on Tsunamis: Paris, France, May 26-28, 1998, Commissariat à l'Energie Atomique (CEA), p. 211-223.

Hamilton, Sarah, and Shennan, Ian, 2005, Late Holocene great earthquakes and relative sea-level change at Kenai, southern Alaska: Journal of Quaternary Science, v. 20, no. 2, p. 95-111.

Hampton, M.A., Lee, H.J., and Locat, Jacques, 1996, Submarine landslides: Reviews of Geophysics, v. 34, no. 1, p. 33-59.

Hampton, M.A., Lemke, R.W., and Coulter, H.W., 2002, Submarine landslides that had a significant impact on man and his activities — Seward and Valdez, Alaska, in Schwab, W.C., Lee, H.J., and Twichell, D.C., eds., Submarine landslides-Selected studies in the U.S. Exclusive Economic Zone: U.S. Geological Survey Bulletin 2002, p. 123-134.

Holdahl, S.R., and Sauber, Jeanne, 1994, Coseismic slip in the 1964 Prince William Sound earthquake-A new geodetic inversion: Pure and Applied Geophysics, v. 142, no. 1, p. 55-82.

Ichinose, Gene, Somerville, Paul, Thio, H.K., Graves, Robert, and O’Connell, Dan, 2007, Rupture process of the 1964 Prince William Sound, Alaska, earthquake from the combined inversion of seismic, tsunami, and geodetic data: Journal of Geophysical Research, v. 112, no. B07, p. 306, 21 p., doi:10.1029/2006JB004728.
Jiang, Lin, and LeBlond, P.H., 1992, The coupling of a submarine slide and the surface waves which it generates: Journal of Geophysical Research, v. 97, no. C8, p. 12,731-12,744.

Jiang, Lin, and LeBlond, P.H., 1994, Three-dimensional modeling of tsunami generation due to a submarine mudslide: Journal of Physical Oceanography, v. 24, no. 3, p. 559-572.

Johnson, J.M., Satake, Kenji, Holdahl, S.R., and Sauber, Jeanne, 1996, The 1964 Prince William Sound earthquake-Joint inversion of tsunami waveforms and geodetic data: Journal of Geophysical Research, v. 101, no. B1, p. 523-532.

Kachadoorian Reuben, 1965, Effects of the earthquake of March 27, 1964, at Whittier, Alaska: U.S. Geological Survey Professional Paper 542-B, p. B1-B21, 3 sheets, scale 1:4,800.

Kulikov, E.A., Rabinovich, A.B., Fine, I.V., Bornhold, B.D., and Thomson, R.E., 1998, Tsunami generation by landslides at the Pacific coast of North America and the role of tides: Oceanology, v. 38, no. 3, p. 323-328.

Lander, J.F., 1996, Tsunamis affecting Alaska, 17371996: Boulder, Colorado, National Geophysical Data Center (NGDC), NOAA, Key to Geophysical Research Documentation v. 31, 195 p.

Leica Geosystem AG, 2002, GPS User manual, Version 4, Leica Geosystems AG, Heerbrugg, Switzerland, $62 \mathrm{p}$.

Lemke, R.W., 1967, Effects of the Earthquake of March 27, 1964, at Seward, Alaska: U.S. Geological Survey Professional Paper 542-E, 43 p., 2 sheets, scale 1:63,360.

Lim, E., Eakins, B.W., and Wigley, R., 2009, Southern Alaska coastal relief model-Procedures, Data Sources, and Analysis: National Geophysical Data Center, NOAA, 25 p., http://www.ngdc.noaa.gov/ mgg/coastal/s alaska.html.

National Tsunami Hazard Mapping Program (NTHMP), 2010, Guidelines and best practices for tsunami inundation modeling for evacuation planning: National Oceanic and Atmospheric Administration, NTHMP Mapping \& Modeling Subcommittee, ftp://ftp.ngdc. noaa.gov/pub/outgoing/heather/MMS/2011_02National/NTHMP_Modeling_Mapping_Guidelines. pdf, 7 p.

Nicolsky, D.J., Suleimani, E.N., and Hansen, R.A., 2011, Validation and verification of a numerical model for tsunami propagation and runup: Pure and Applied Geophysics, v. 168, p. 1,199-1,222, http://dx.doi. org/10.1007/s00024-010-0231-9.

Nishenko, S.P., and Jacob, K.H., 1990, Seismic potential of the Queen Charlotte-Alaska-Aleutian seismic zone: Journal of Geophysical Research, v. 95, no. B3, p. 2,511-2,532. 
Okada, Yoshimitsu, 1985, Surface deformation due to shear and tensile faults in a half-space: Bulletin of the Seismological Society of America, v. 75, no. 4, p. 1,135-1,154.

Page, R.A., Biswas, N.N., Lahr, J.C., and Pulpan, Hans, 1991, Seismicity of continental Alaska, in Slemmons, D.B., Engdahl, E.R., Zoback, M.D., and Blackwell, D.D., eds., Neotectonics of North America: Boulder, Colorado, Geological Society of America, Decade Map Volume 1, p. 47-68.

Plafker, George, 1967, Surface faults on Montague Island associated with the 1964 Alaska earthquake: U.S. Geological Survey Professional Paper 543-G, p. G1-G42.

1969, Tectonics: U.S. Geological Survey Professional Paper 543-I, p. G1-G74.

Plafker, George, and Thatcher, Wayne, 2008, Geologi$\mathrm{cal}$ and geophysical evaluation of the mechanisms of the Great 1899 Yakutat Bay Earthquakes, in Freymueller, J.T., Haeussler, P.J., Wesson, R.L., and Ekström, Goran, eds., Active tectonics and seismic potential of Alaska: Geophysical Monograph Series, v. 179, p. 215-236, ISBN 978-0-87590-444-3, doi 10.1029/179GM12, AGU code GM1794443.

Plafker, George, Carver, G.A., and Clarke, S.H., Jr., 2000, Seismotectonics of the 1964 Alaska earthquake as an analog for future tsunamigenic southern Cascadia subduction earthquakes, in Clague, J.J., Atwater, B.F., Wang, Kelin, Wang, M.M., and Wong, I.G, compilers, Program summary and abstracts, Geological Society of America Penrose Conference, Great Cascadia Earthquake Tricentennial: Oregon Department of Geology and Mineral Industries Special Paper 33, p. 96-97.

Plafker, George, Kachadoorian, Reuben, Eckel, E.B., and Mayo, L.R., 1969, Effects of the earthquake of March 27, 1964 on various communities: U.S. Geological Survey Professional Paper 542-G, 50 p.

Priest, G.R., Goldfinger, Chris, Wang, Kelin, Witter, R.C., Zhang, Yinglong, and Baptista, A.M., 2009, Confidence levels for tsunami-inundation limits in northern Oregon inferred from a 10,000-year history of great earthquakes at the Cascadia subduction zone: Natural Hazards, v. 54, no. 1, DOI 10.1007/ s11069-009-9453-5.

Rabinovich, A.B., Thomson, R.E., Bornhold, B.D., Fine, I.V., and Kulikov, E.A., 2003, Numerical modeling of tsunamis generated by hypothetical landslides in the Strait of Georgia, British Columbia: Pure and Applied Geophysics, v. 160, no. 7, p. 1,273-1,313.

Santini, S., Dragoni, M., and Spada, G., 2003, Asperity distribution of the 1964 Great Alaska Earthquake and its relation to subsequent seismicity in the region: Tectonophysics, v. 367, no. 3-4, p. 219-233.
Satake, Kenji, Shimazaki, Kunihiko, Tsuji, Yoshinobu, and Ueda, Kazue, 1996, Time and size of a giant earthquake in Cascadia inferred from Japanese tsunami records of January 1700: Nature, v. 379, no. 6562, p. 246-249.

Satake, Kenji, Wang, Kelin, and Atwater, B.F., 2003, Fault slip and seismic moment of the 1700 Cascadia earthquake inferred from Japanese tsunami descriptions: Journal of Geophysical Research, v. 108, no. B11, p. 2,535-2,551, doi:10.1029/2003JB002521.

Savoie, M.A., Savoie, J.M., Trefry, J.H., Semmler, C.M., Woodall, D.W., Trocine, R.P., Brooks, J.M., and McDonald, Tom, 2006, Port Valdez sediment coring program-Final 2004 monitoring report: Kinnetic Laboratories, Inc. in association with Florida Institute of Technology \& TDI Brooks International, Inc., Contract No. 961.04.1 for Prince William Sound Regional Citizens' Advisory Council, Valdez, Alaska, 76 p., http://www.pwsrcac.org/docs/d0024500.pdf.

Shannon, W., and Hilts, D., 1973, Submarine landslide at Seward, in The Great Alaska Earthquake of 1964: Washington, DC, Engineering( National Academy of Sciences), p. 144-156.

Shennan, Ian, Barlow, Natasha, and Combellick, R.A., 2008, Paleoseismological records of multiple great earthquakes in south-central Alaska: A 4000-year record at Girdwood, in, Freymueller, J.T., Haeussler, P.J., Wesson, R.L, and Ekström, G., eds., Active Tectonics and Seismic Potential of Alaska: American Geophysical Union Geophysical Monograph 179, p. 185-199.

Shennan, Ian, Bruhn, Ronald, and Plafker, George, 2009, Multi-segment earthquakes and tsunami potential of the Aleutian megathrust: Quaternary Science Reviews, v. 28, no. 1-2, p. 7-13.

Suito, Hisashi, and Freymueller, J.T., 2009, A viscoelastic and afterslip postseismic deformation model for the 1964 Alaska earthquake: Journal of Geophysical Research, v. 114, no. B11, p. 404-426, doi:10.1029/2008JB005954.

Suleimani, E.N., Combellick, R.A., Marriott, Duncan, Hansen, R.A., Venturato, A.J., and Newman, J.C., 2005, Tsunami hazard maps of the Homer and Seldovia areas, Alaska: Alaska Division of Geological \& Geophysical Surveys Report of Investigations 2005-2, 28 p., 2 sheets, scale 1:12,500.

Suleimani, E.N., Hansen, R.A., Combellick, R.A., Carver, G.A., Kamphaus, R.A., Newman, J.C., and Venturato, A.J, 2002, Tsunami hazard maps of the Kodiak area, Alaska: Alaska Division of Geological \& Geophysical Surveys Report of Investigations 2002-1, 16 p., 4 sheets, scale 1:12,500.

Synolakis, C.E., and Bernard, E.N., 2006, Tsunami science before and beyond Boxing Day 2004, in 
Thompson, J.M.T., Heppert, H.E., and Sparks, R.S.J., eds., Extreme natural hazards: Philosophical Transactions of the Royal Society, Mathematical, Physical, and Engineering Sciences, v. 364, no. 1845, p. 2,231-2,265.

Synolakis, C.E., Bernard, E.N., Titov, V.V., Kânoğlu, U., and González, F.I., 2007, Standards, criteria, and procedures for NOAA evaluation of tsunami numerical models: Seattle, Washington, NOAA/Pacific Marine Environmental Laboratory, Technical Memorandum OAR PMEL-135, 55 p.

Thomson, R.E., Rabinovich, A.B., Kulikov, E.A., Fine, I.V., and Bornhold, B.D., 2001, On numerical simulation of the landslide-generated tsunami of November 3, 1994 in Skagway Harbor, Alaska, in Hebenstreit, G.T., ed., Tsunami research at the end of a critical decade: Kluwer, p. 243-282.

Titov, V.V., and Synolakis, C.E., 1995, Evolution and runup of breaking and nonbreaking waves using VTSC-2: Journal of Waterway, Port, Coastal and Ocean Engineering, v. 121, no. 6, p. 308-316.

1997, Extreme inundation flows during the Hokkaido-Nansei-Oki Tsunami. Geophysical Research Letters, v. 24, no. 11, p, 1,315-1,318.
Tudor, W.J., 1964, Tsunami damage at Kodiak, Alaska, and Crescent City, California, from Alaskan Earthquake of 27 March 1964: Port Hueneme, California, U.S. Navy Civil Engineering Lab, Technical Note N-622, 124 p.

Wang, Kelin, Wells, R.E., Mazzotti, Stephane, Hyndman, R.D., and Sagiya, Takeshi, 2003, A revised dislocation model of interseismic deformation of the Cascadia subduction zone: Journal of Geophysical Research, v. 108, no. B1, p. 2026-2038, doi:10.1029/2001JB001227, http://www.agu.org/ pubs/crossref/2003/2001JB001227.shtml.

Wilson, B.W., and Tørum, Alf, 1968, The tsunami of the Alaskan Earthquake, 1964-Engineering evaluation: Fort Belvoir, Virginia, U.S. Army Corps of Engineers Coastal Engineering Research Center, Technical Memorandum No. 25, 410 p.

1972, Effects of the tsunamis-An engineering study, in The Great Alaska Earthquake of 1964: Washington, D.C., National Academy of SciencesEngineering, p. 361-526. 
INTENTIONALLY LEFT BLANK 


\section{APPENDIX A}

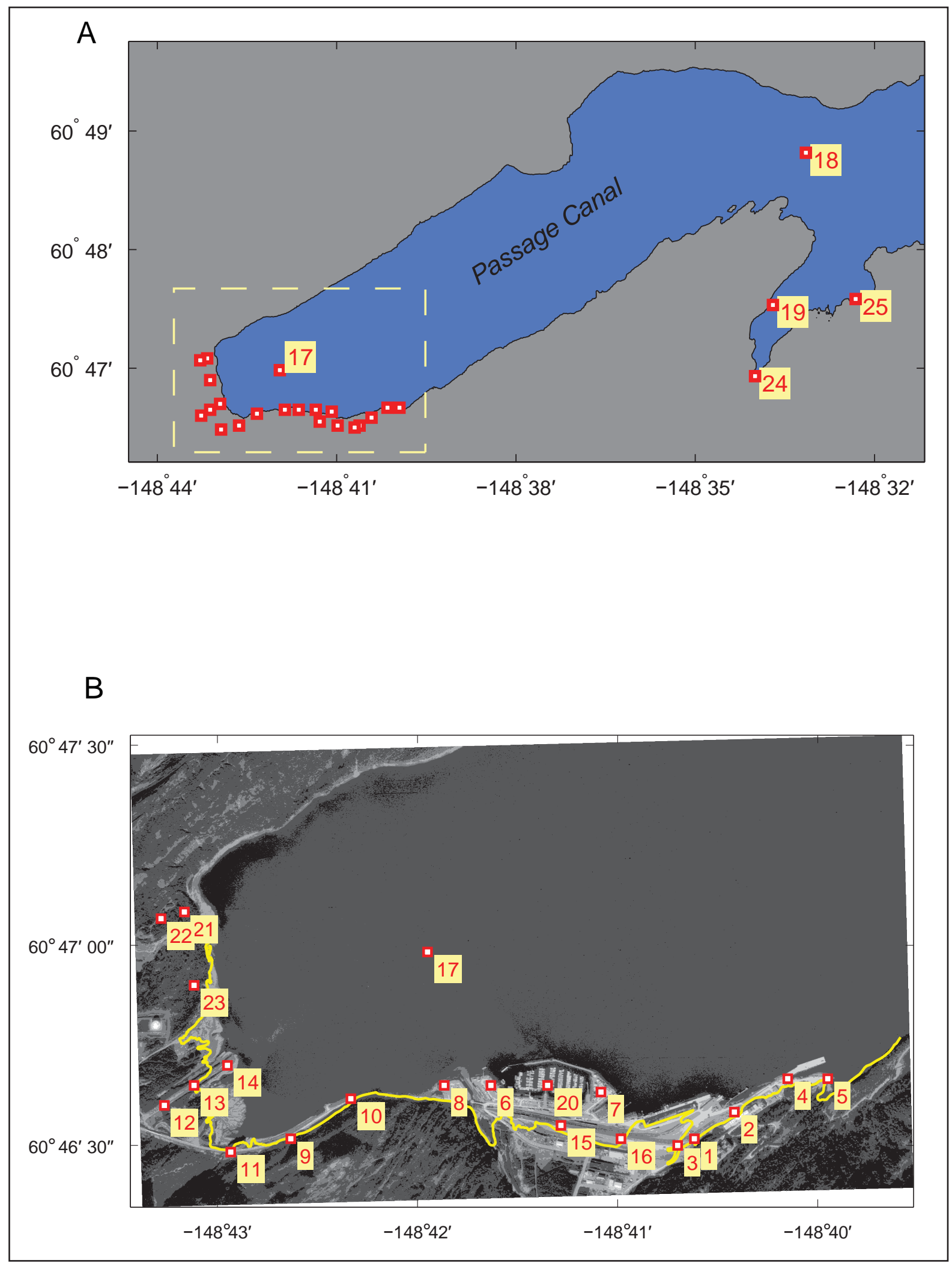

Figure A-1. (A) Locations of time series points in Passage Canal. (B) Closer view of the area marked by a dashed rectangle in figure A, identifying locations of time series points in Passage Canal. 


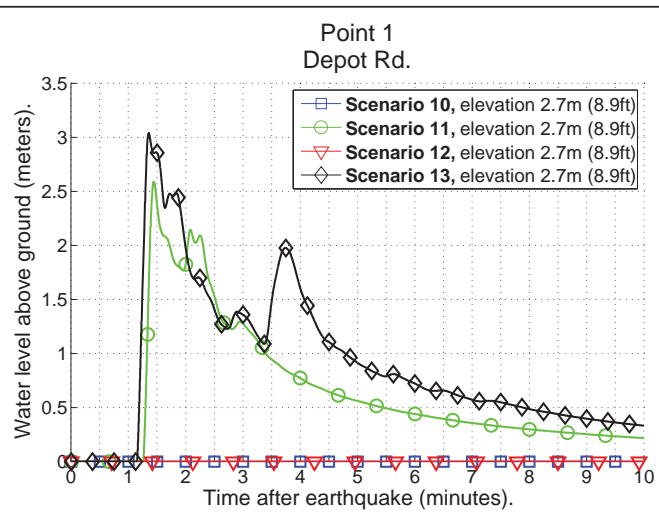

Point 2

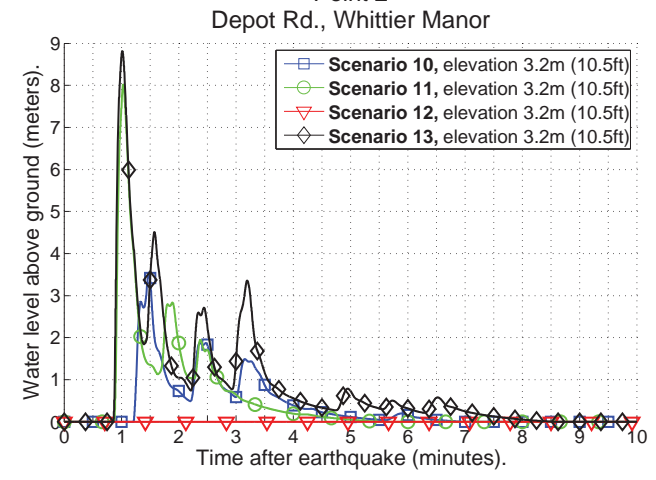

Point 3

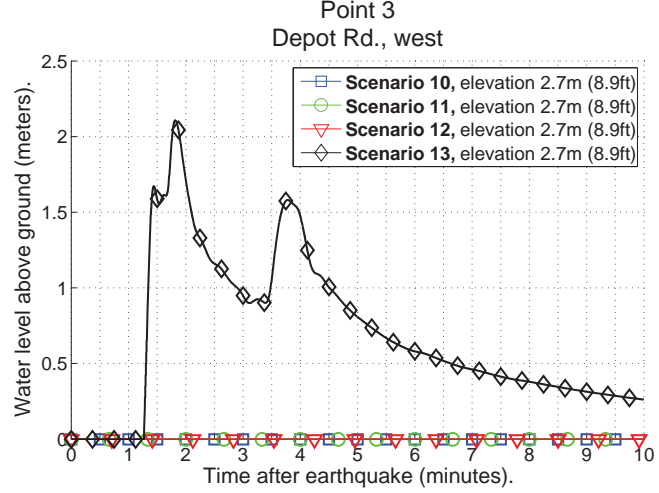

Point 4

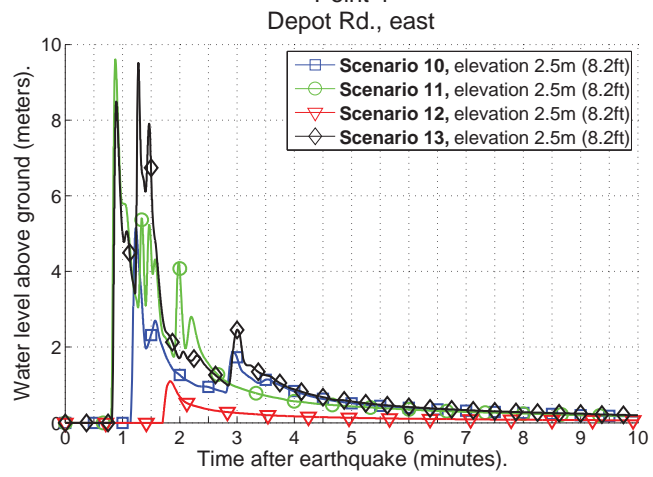

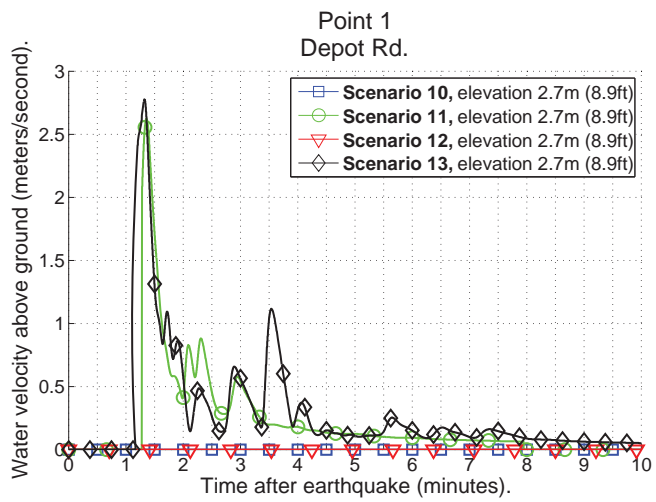

Point 2

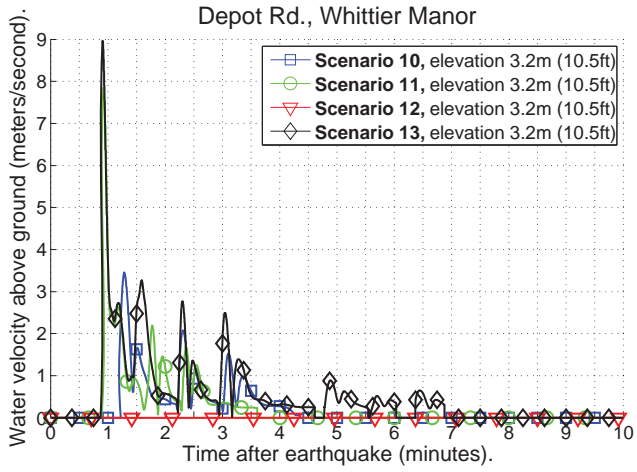

Point 3

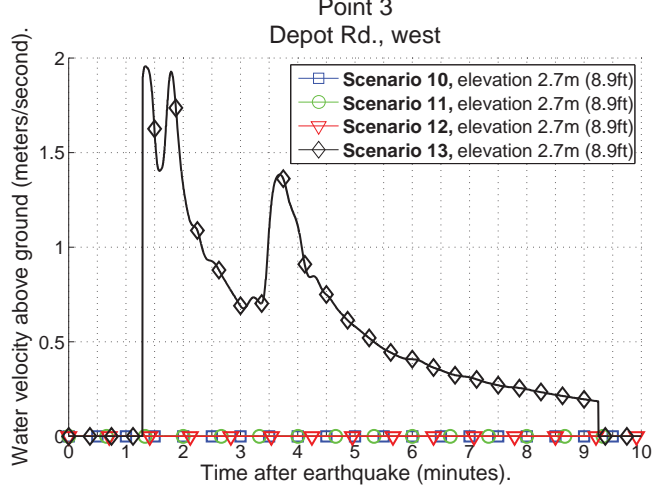

Point 4

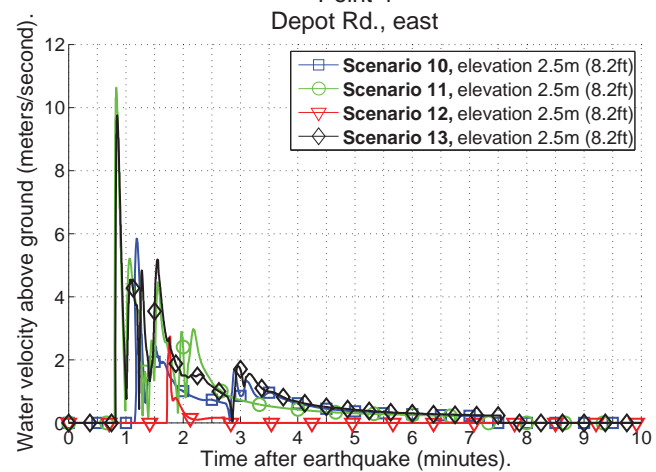

Figure A-2. Time series of the water level and velocity at the selected locations for scenarios 10-13. 

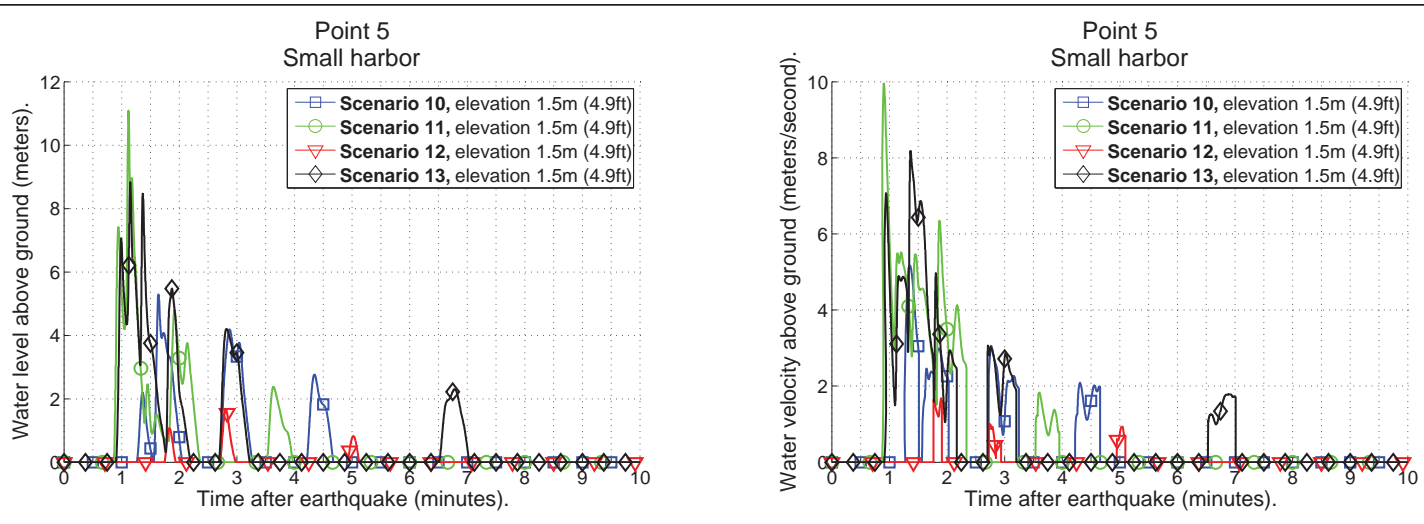

Point 6

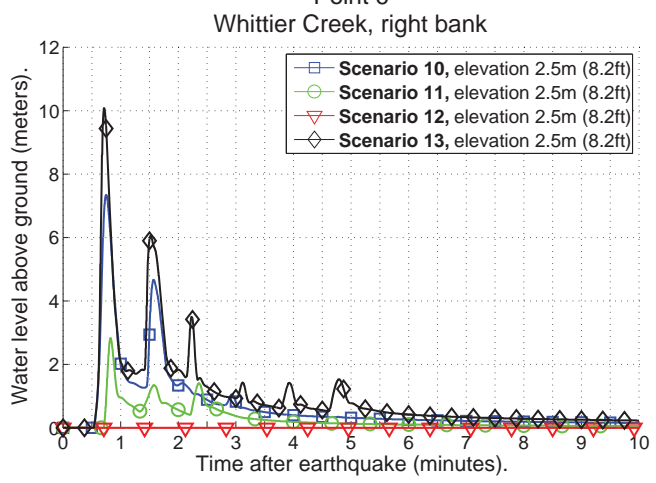

Point 6

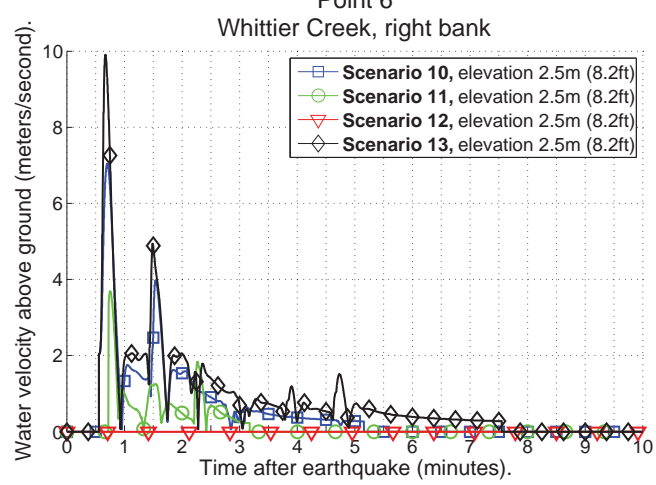

Point 7

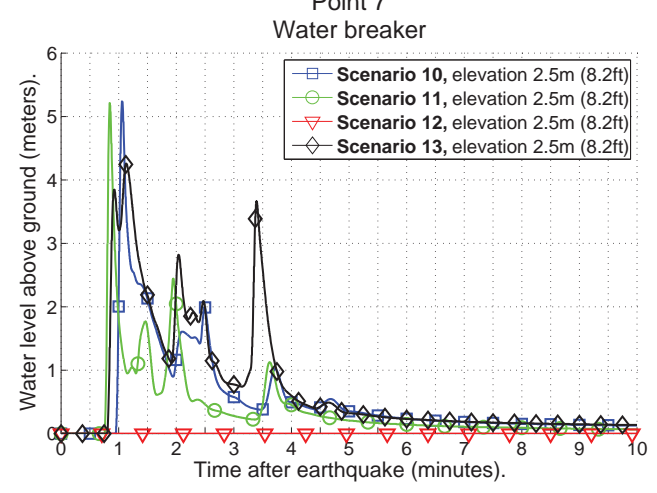

Point 7

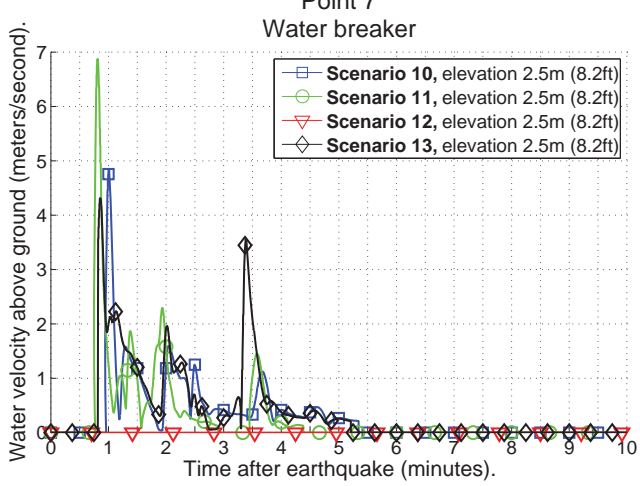

Point 8

Whittier Creek, left bank

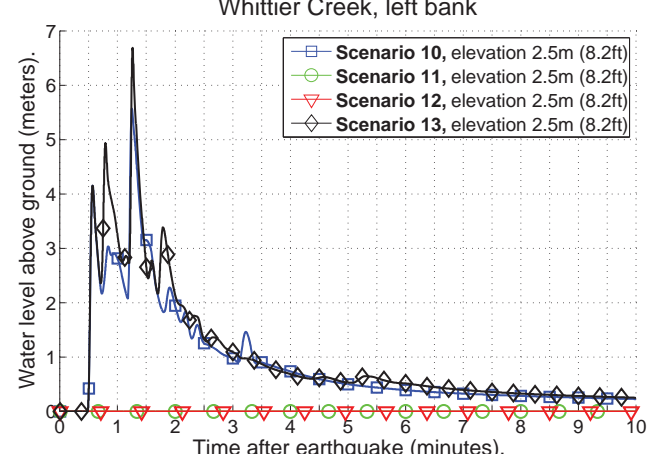

Point 8

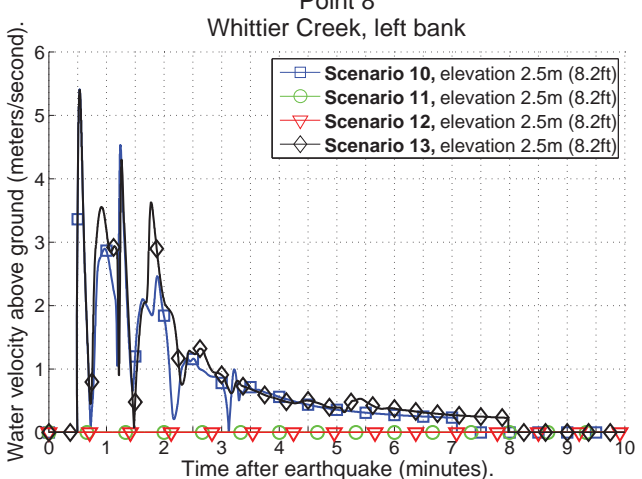

Figure A-2 (continued). Time series of the water level and velocity at the selected locations for scenarios 10-13. 


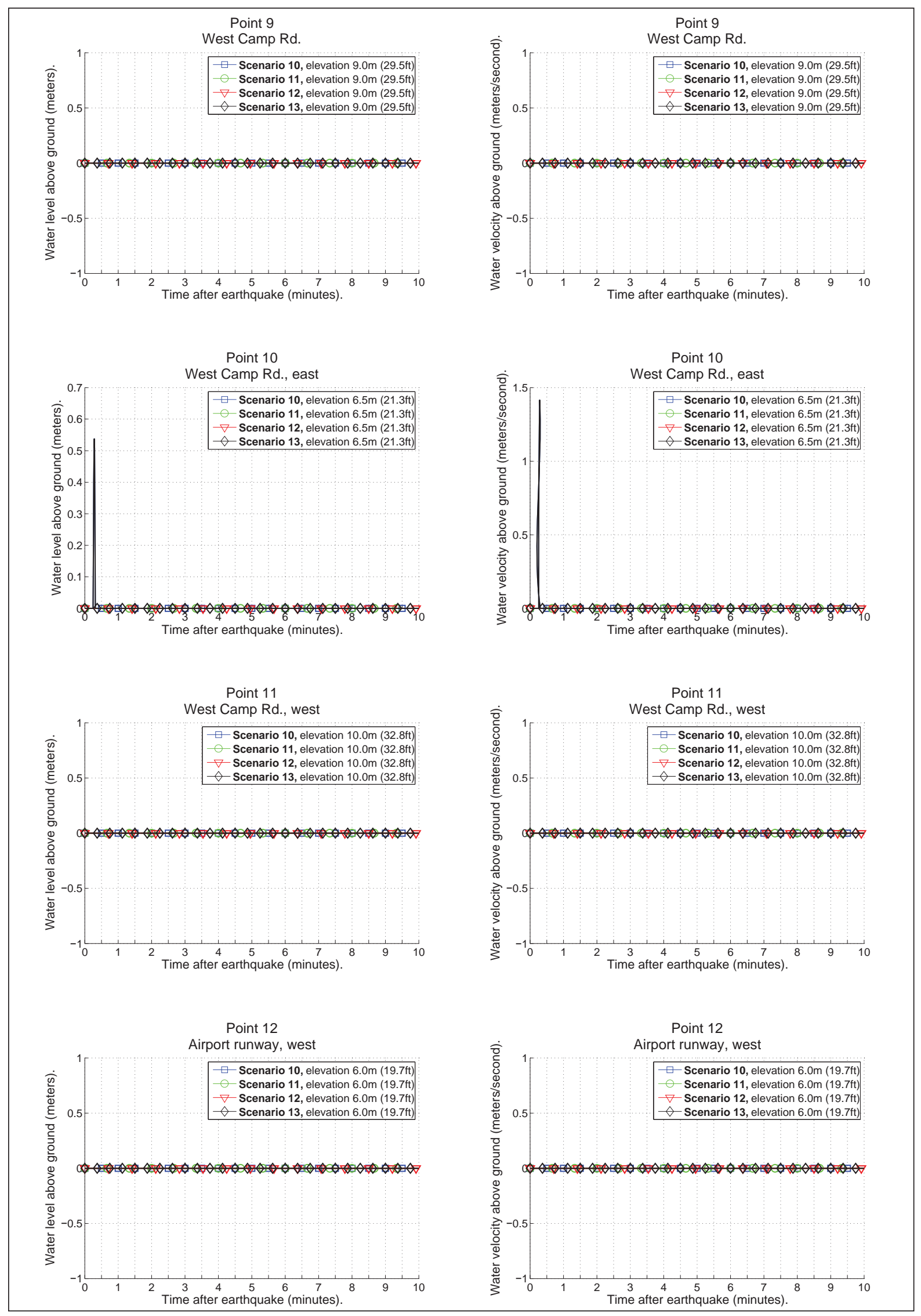

Figure A-2 (continued). Time series of the water level and velocity at the selected locations for scenarios 10-13. 


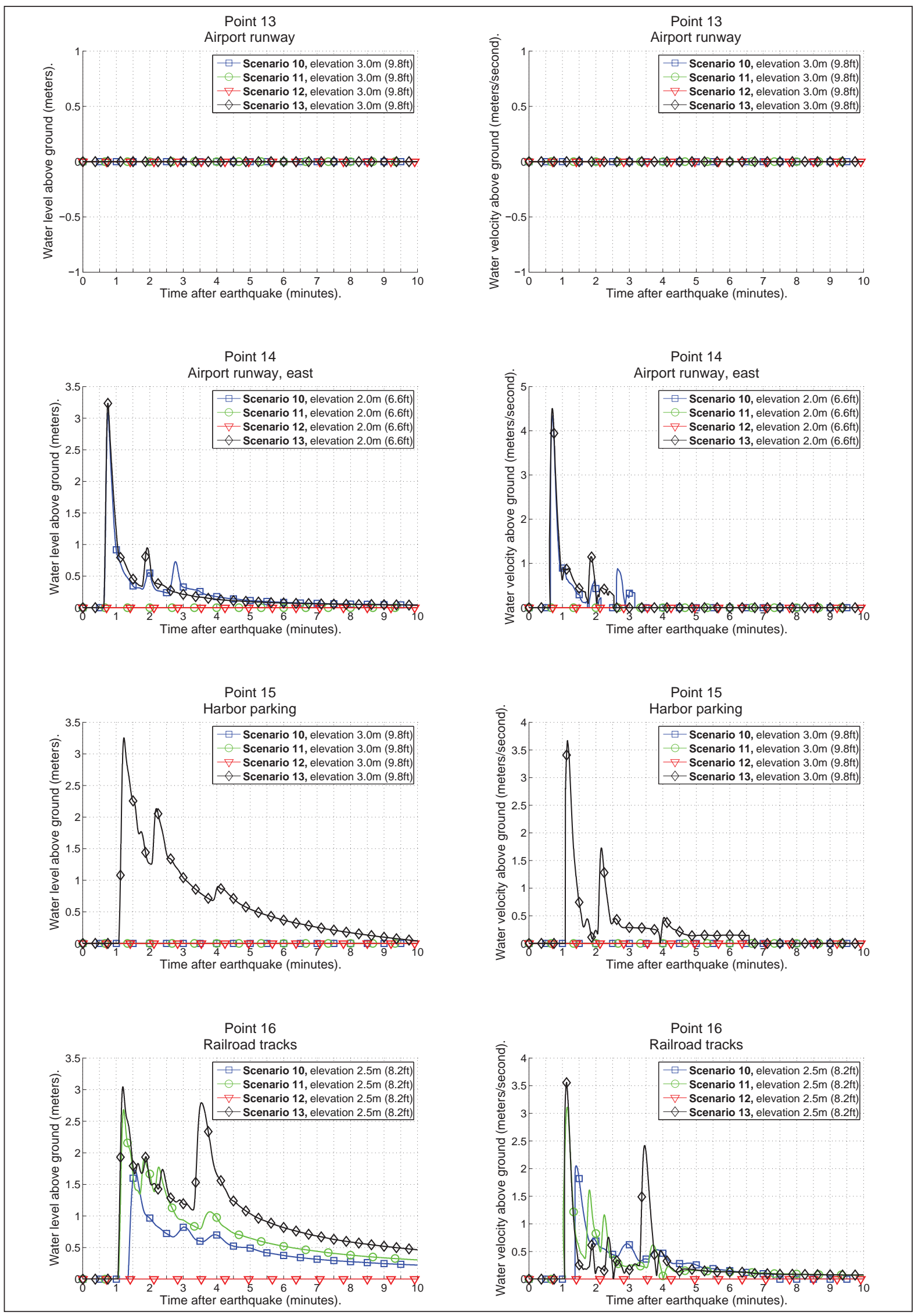

Figure A-2 (continued). Time series of the water level and velocity at the selected locations for scenarios 10-13. 

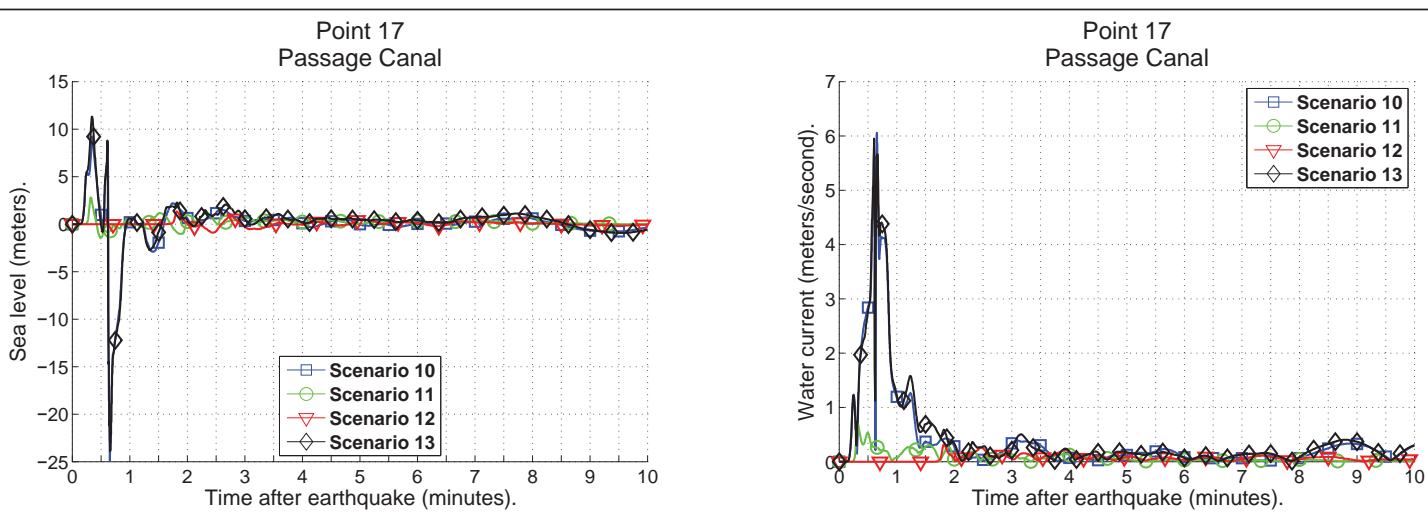

Point 18

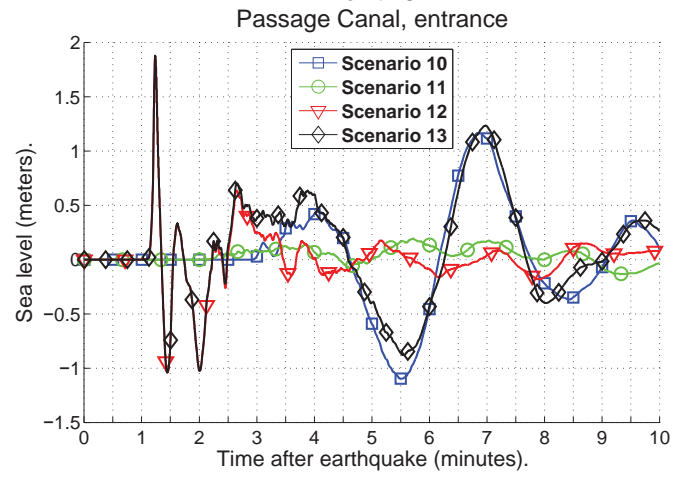

Point 18

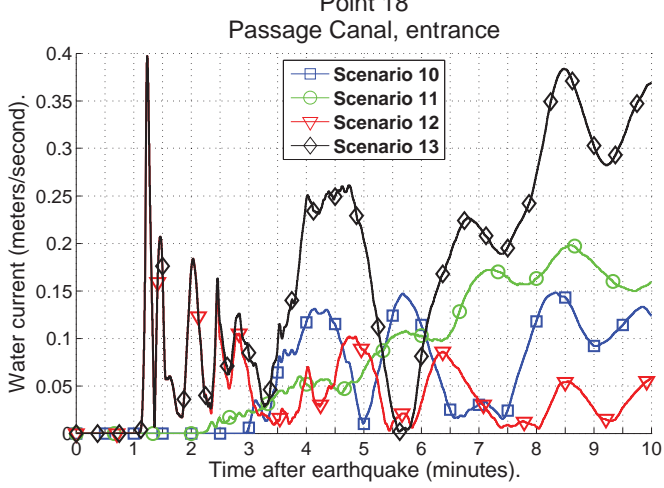

Point 19

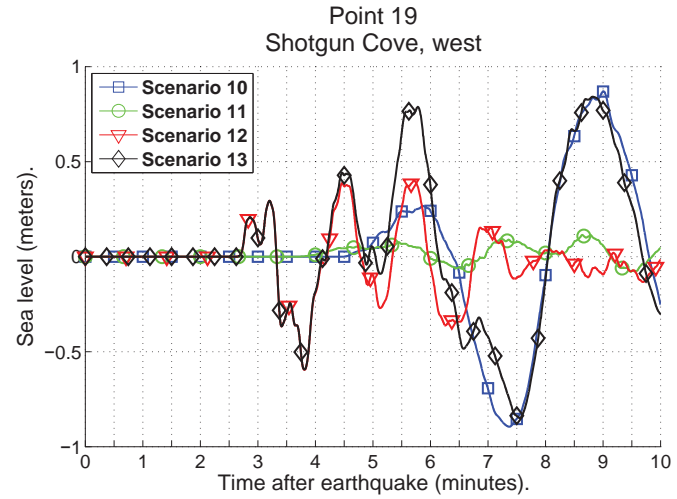

Point 19

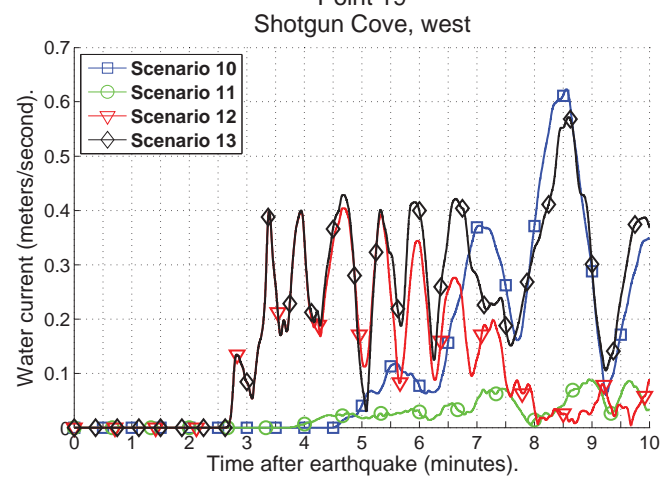

Point 20
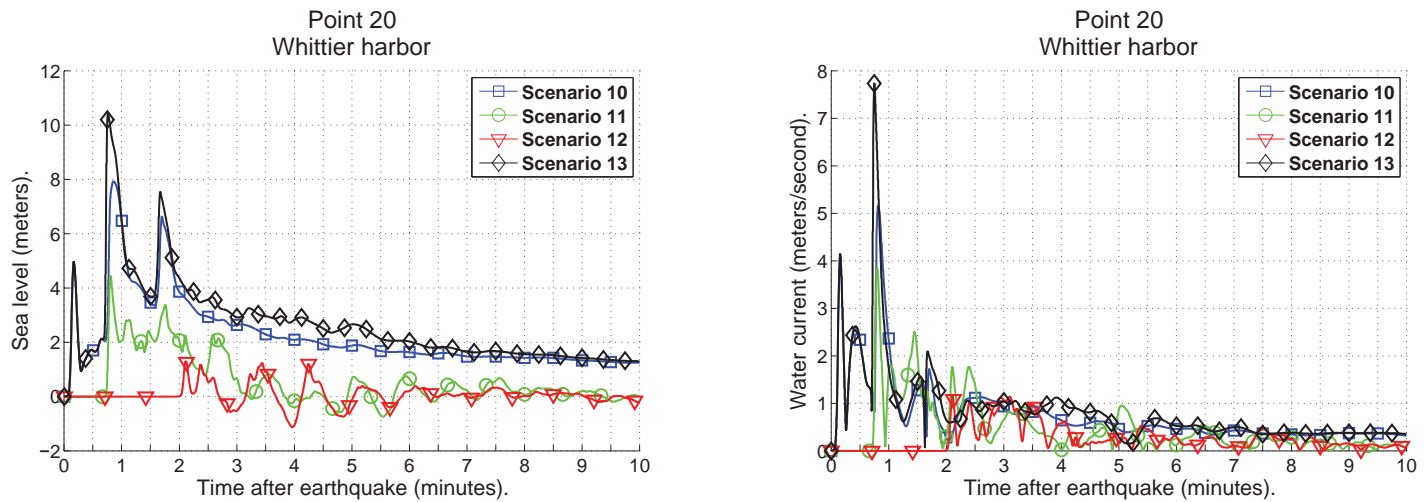

Figure A-2 (continued). Time series of the water level and velocity at the selected locations for scenarios 10-13. 


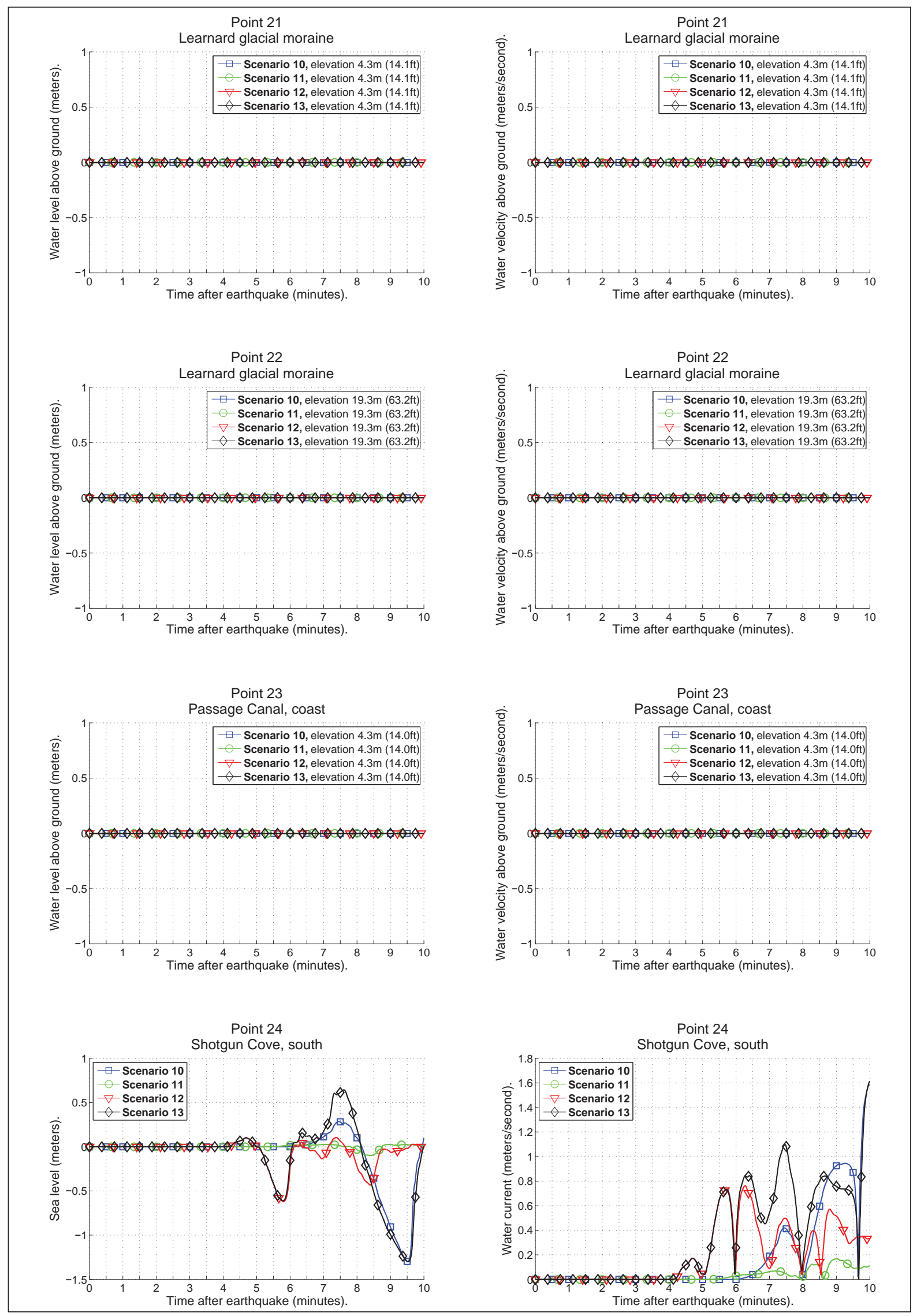

Figure A-2 (continued). Time series of the water level and velocity at the selected locations for scenarios 10-13. 


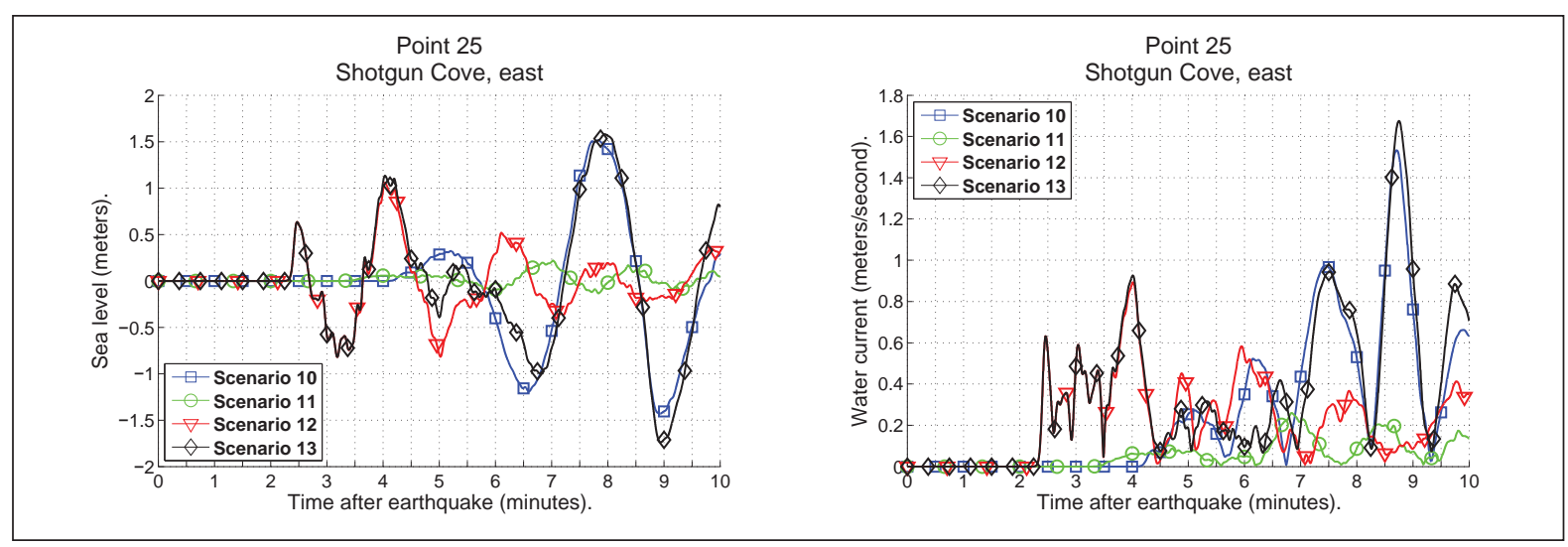

Figure A-2 (continued). Time series of the water level and velocity at the selected locations for scenarios 10-13. 


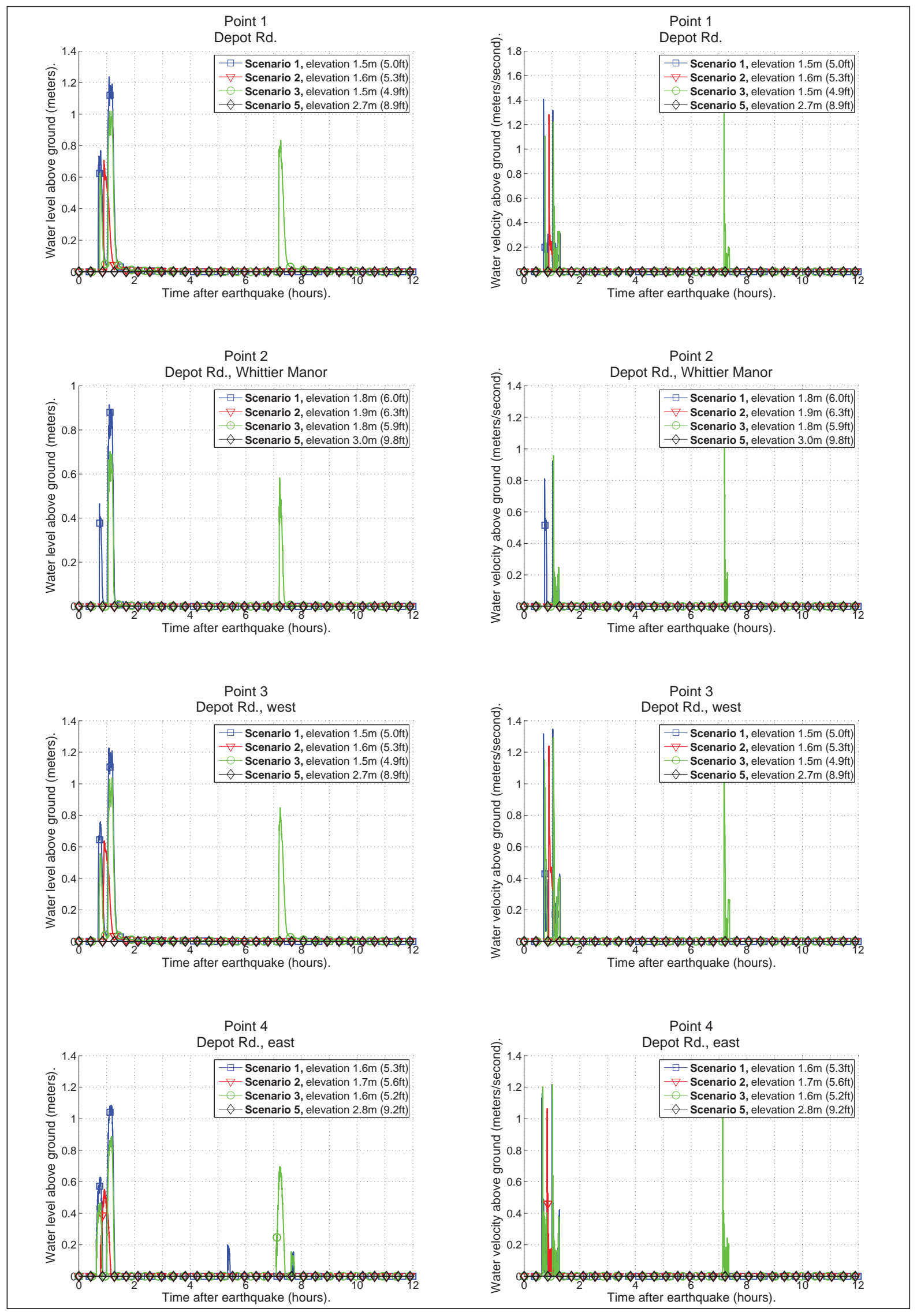

Figure A-3. Time series of water level and velocity at selected locations for scenarios 1, 2, 3, and 5. 


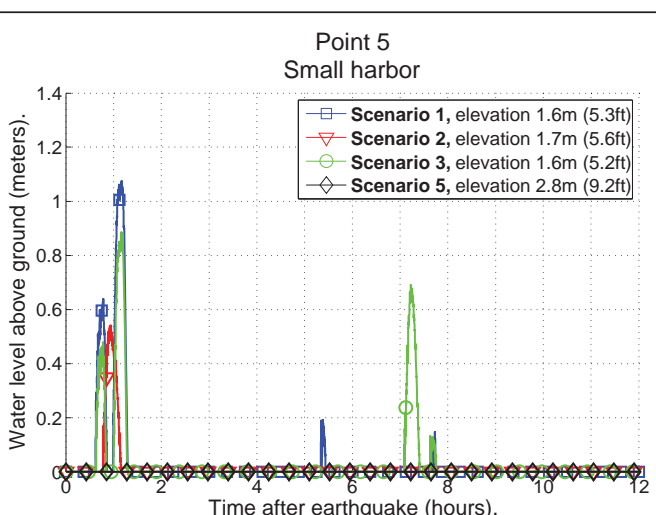

Point 6

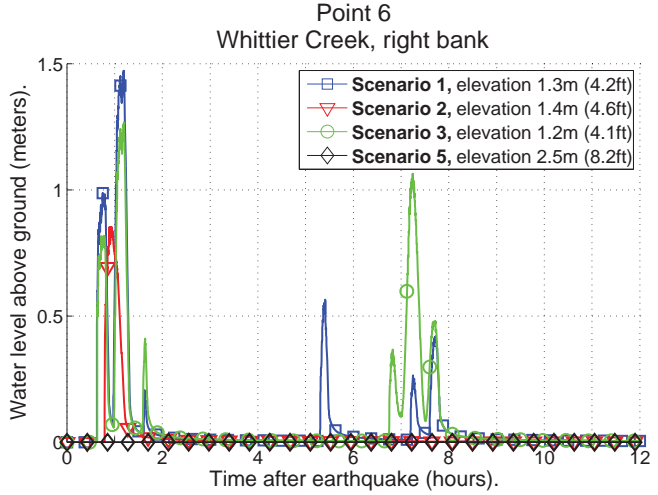

Point 7

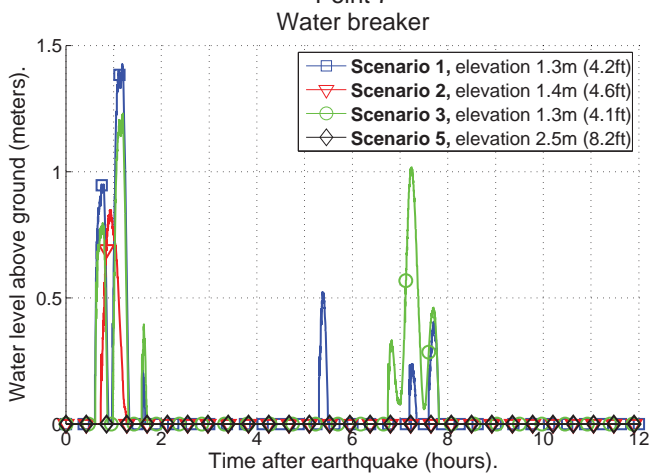

Point 8

Whittier Creek, left bank

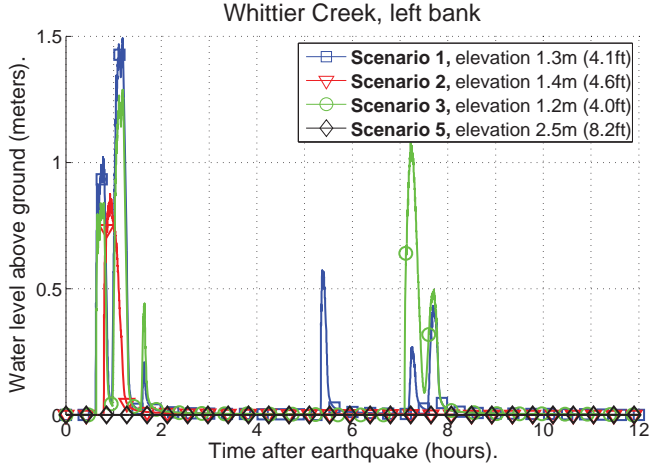

Point 5

Small harbor

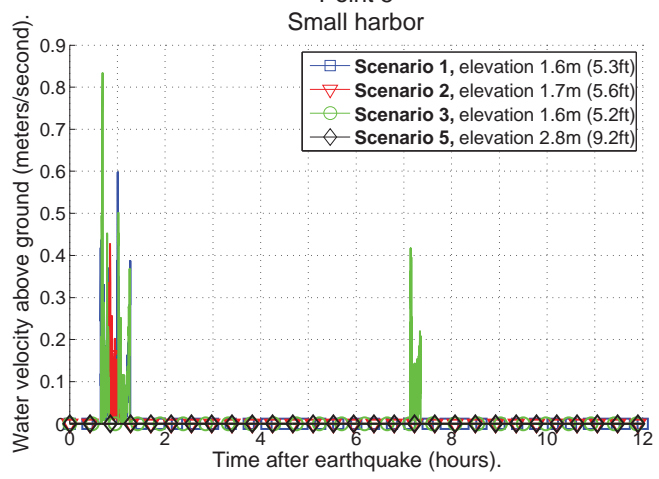

Point 6

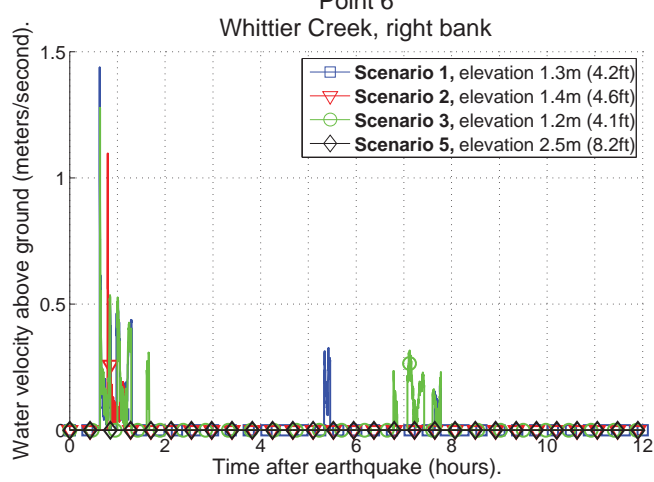

Point 7

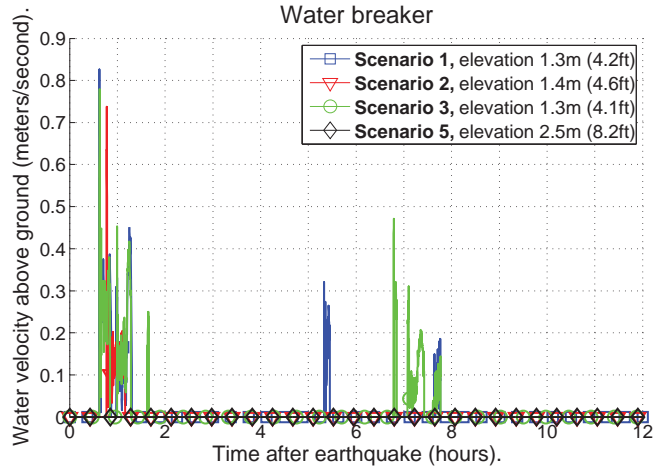

Point 8

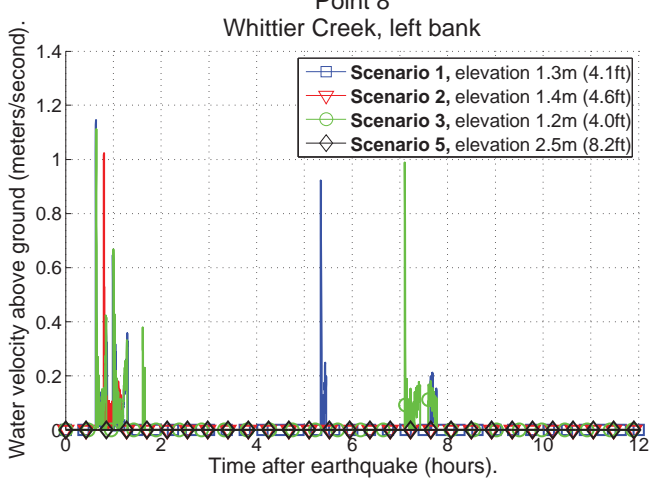

Figure A-3 (continued). Time series of water level and velocity at selected locations for scenarios 1, 2, 3, and 5. 


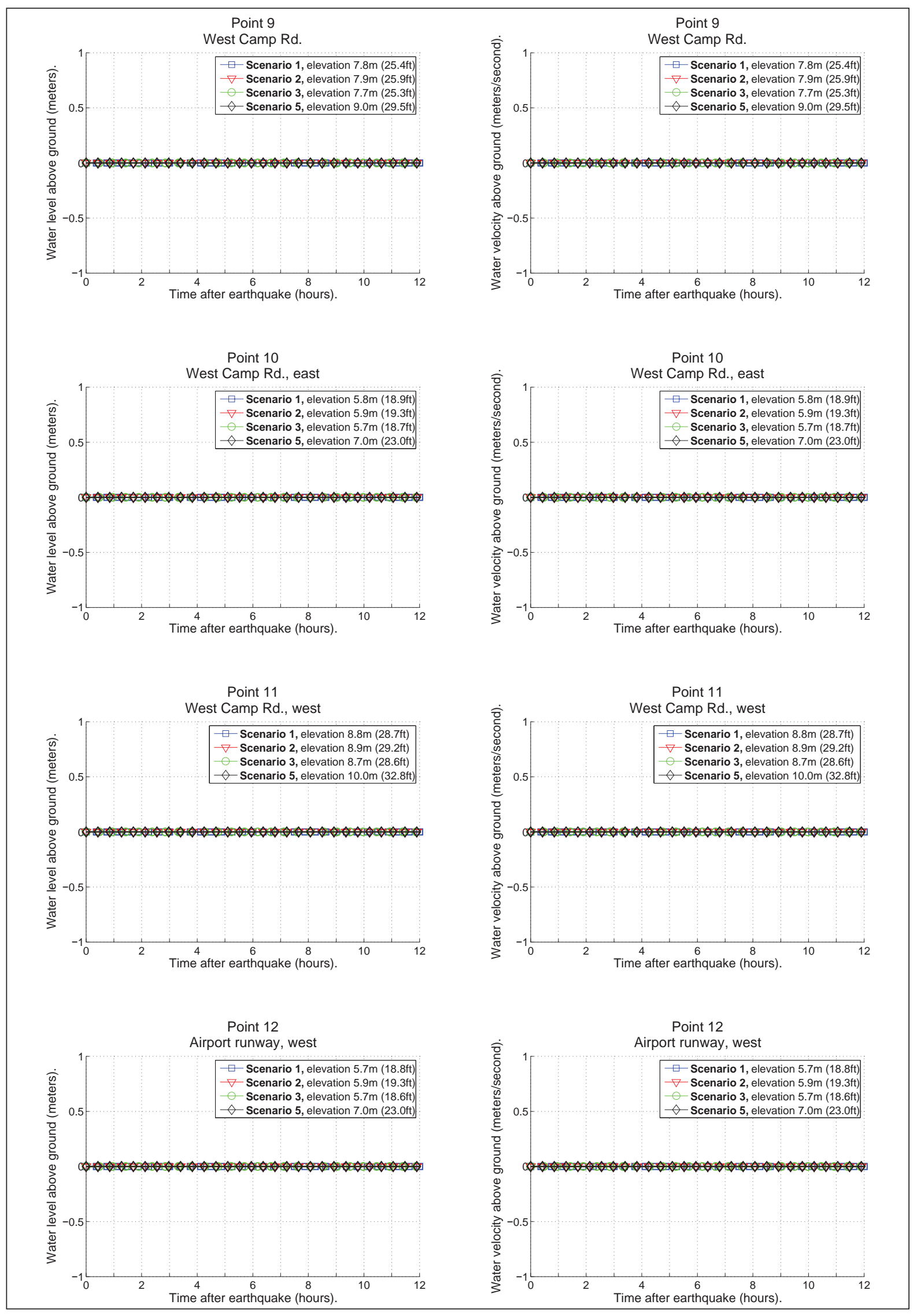

Figure A-3 (continued). Time series of water level and velocity at selected locations for scenarios 1, 2, 3, and 5. 


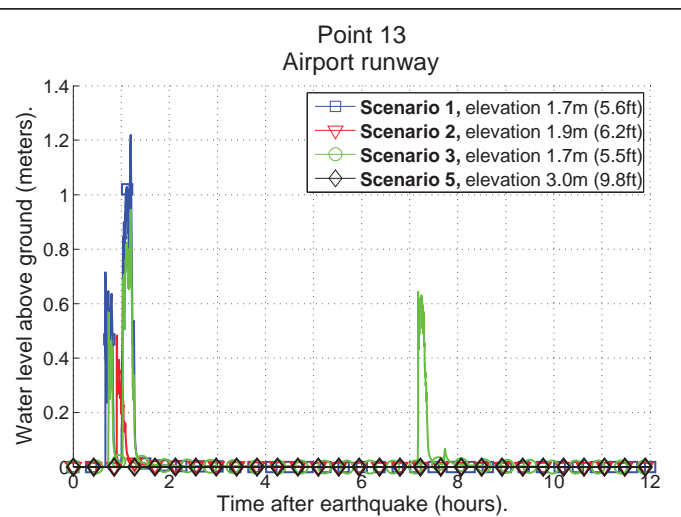

Point 14

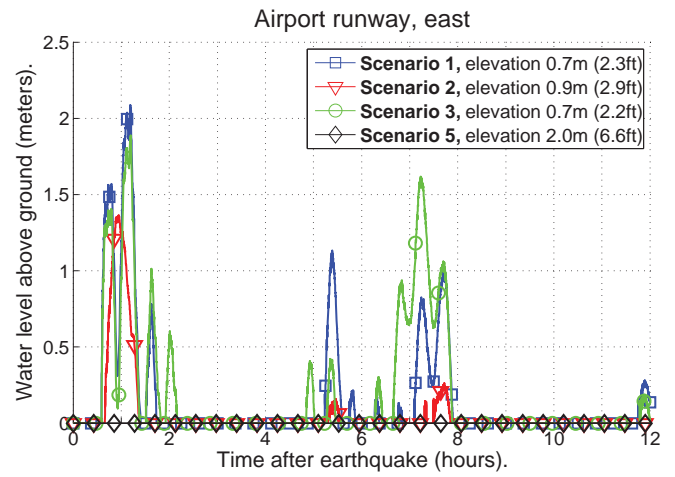

Point 15

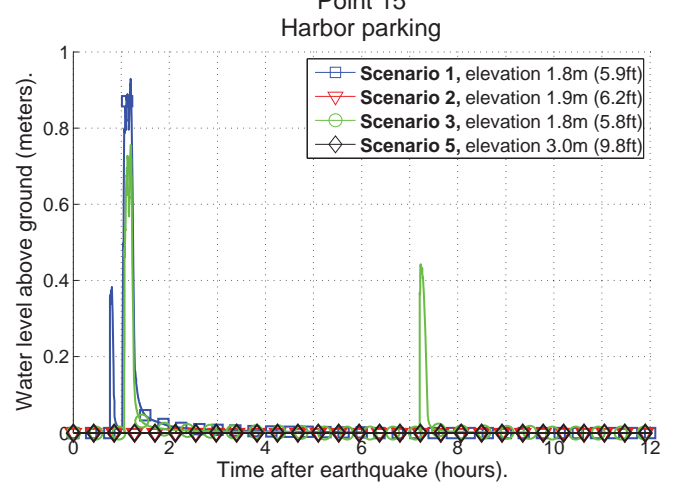

Point 16

Railroad tracks

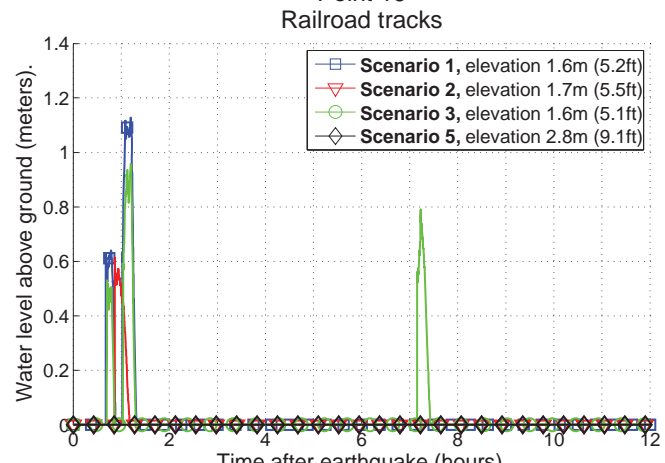

Point 13

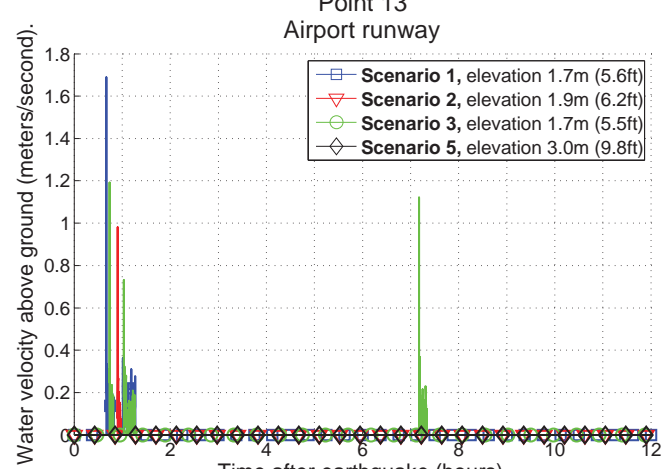

Time after earthquake (hours).

Point 14

Airport runway, east

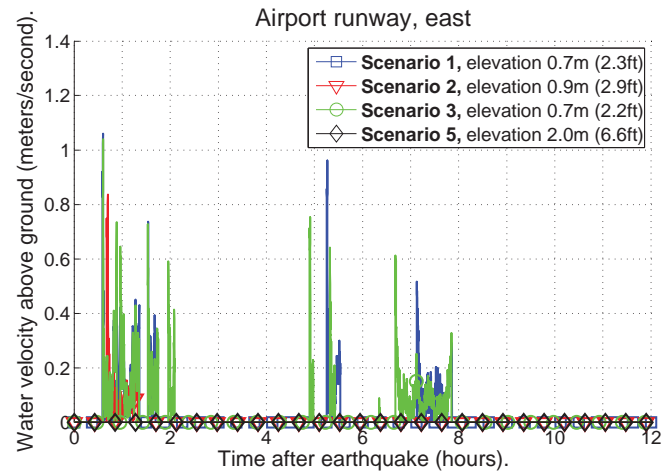

Point 15

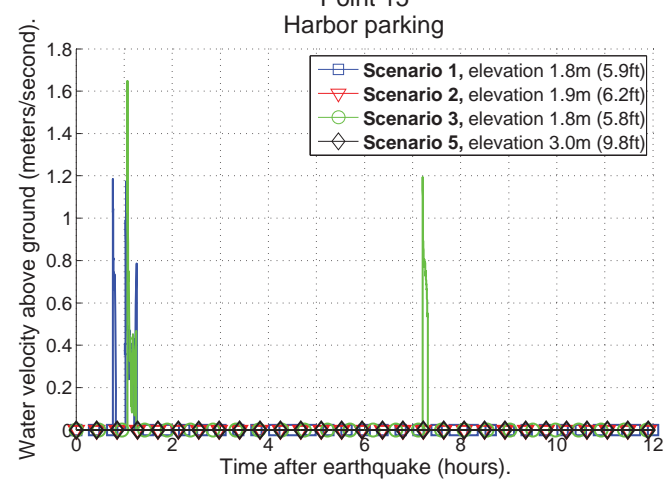

Point 16

Railroad tracks

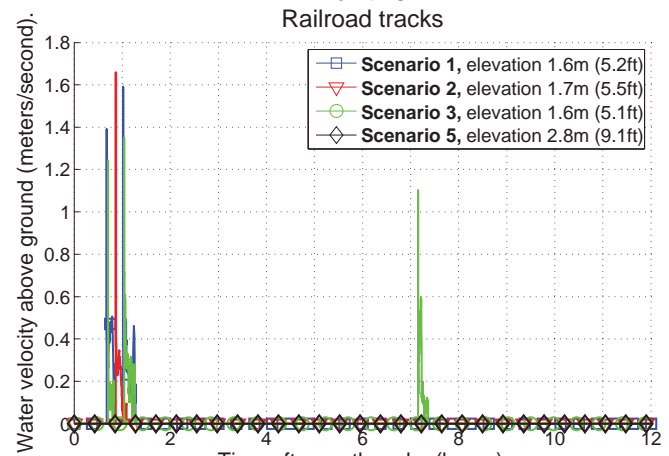

Time after earthquake (hours).

Figure A-3 (continued). Time series of water level and velocity at selected locations for scenarios 1, 2, 3, and 5. 

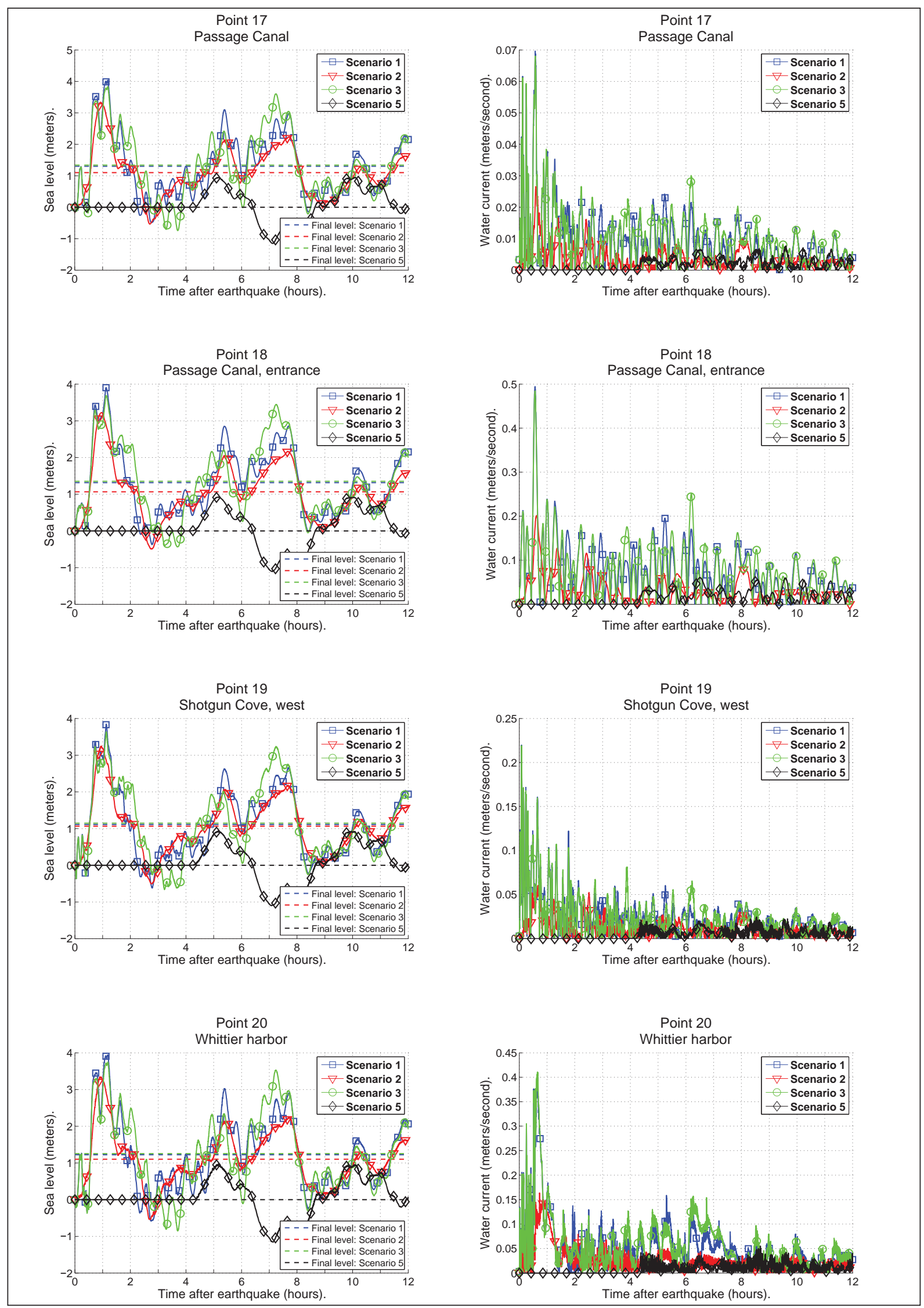

Figure A-3 (continued). Time series of water level and velocity at selected locations for scenarios 1, 2, 3, and 5. 

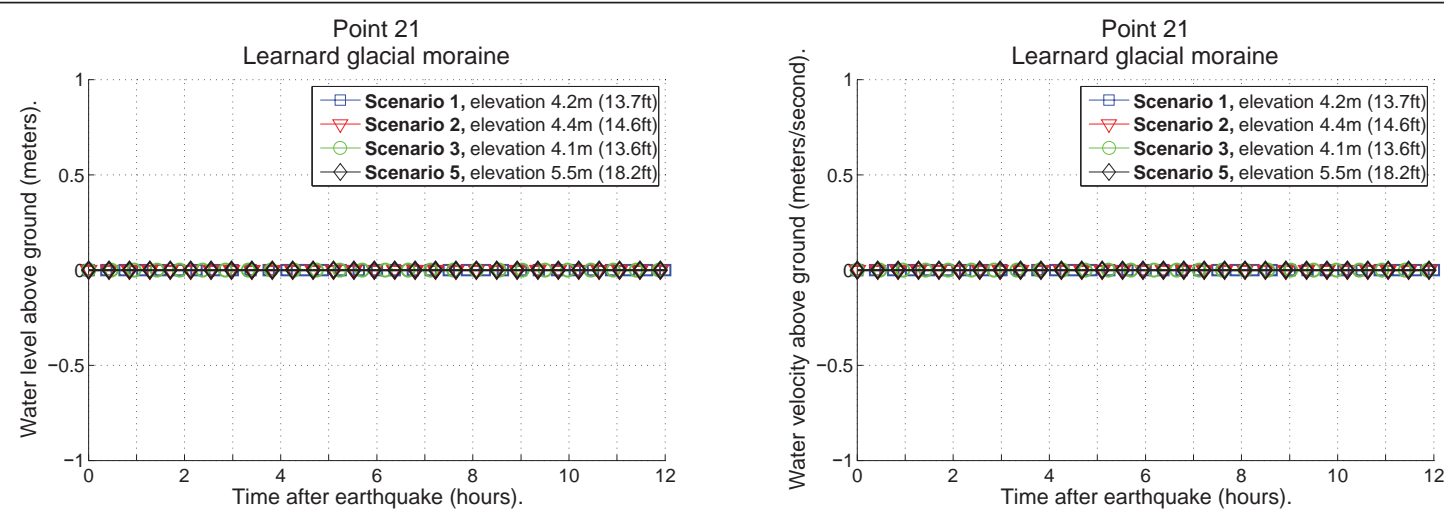

Point 22
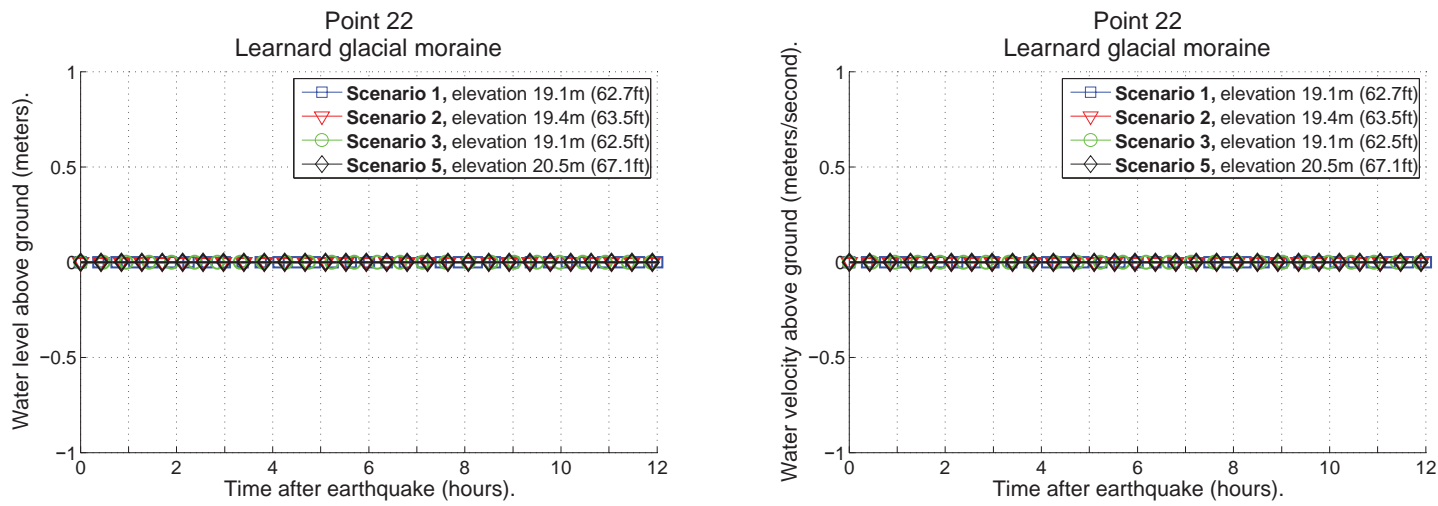

Point 23
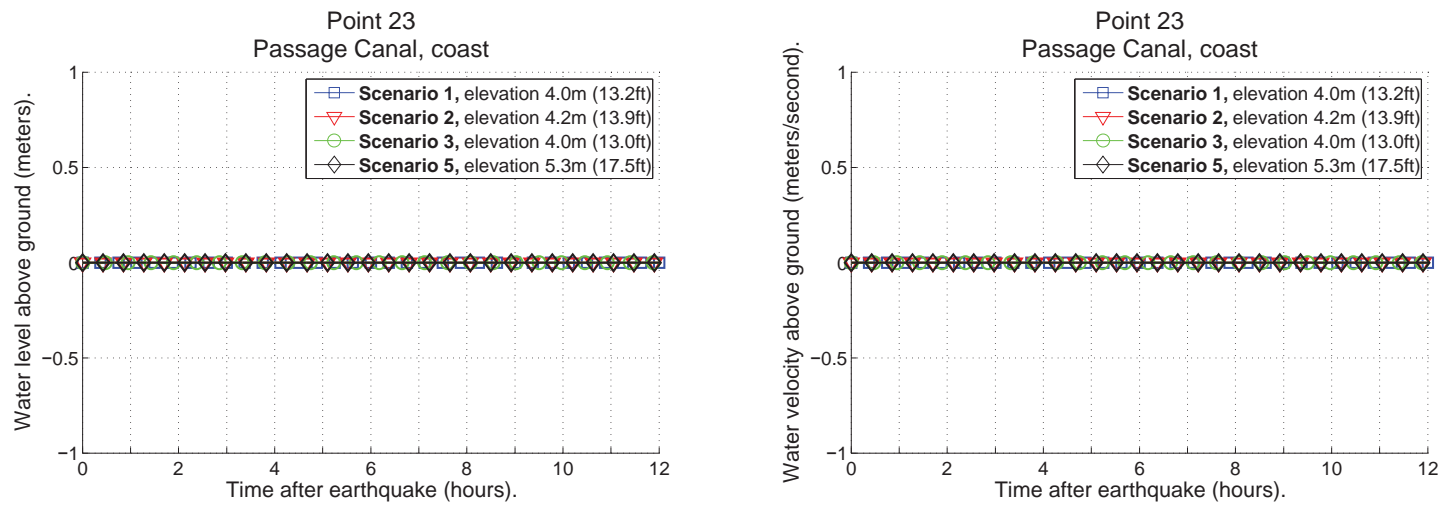

Point 24

Shotgun Cove, south

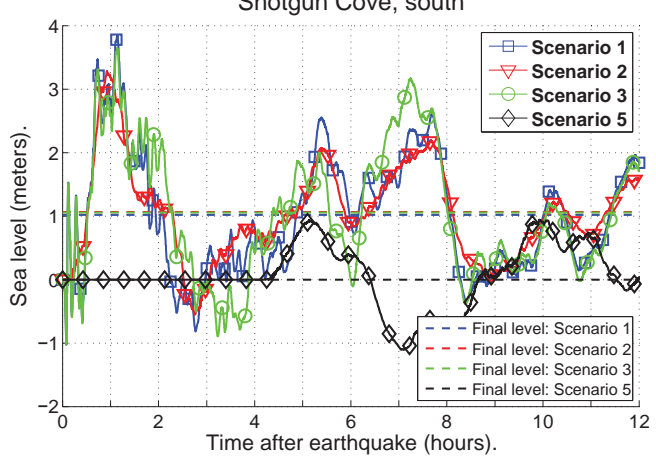

Point 24

Shotgun Cove, south

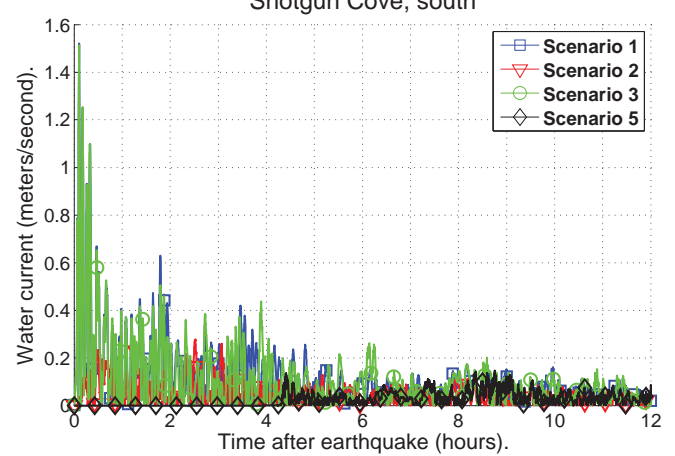

Figure A-3 (continued). Time series of water level and velocity at selected locations for scenarios 1, 2, 3, and 5. 


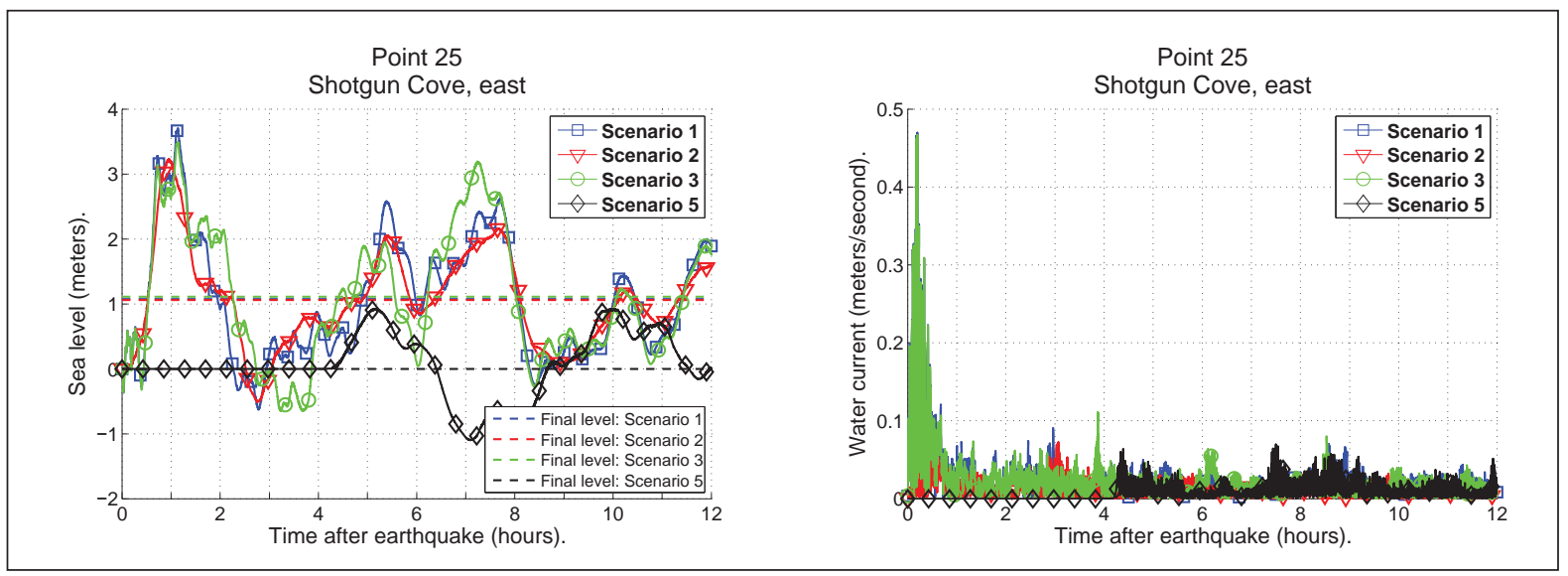

Figure A-3 (continued). Time series of water level and velocity at selected locations for scenarios 1, 2, 3, and 5. 
INTENTIONALLY LEFT BLANK 


\section{APPENDIX B}

\section{Potential rockfall-generated tsunami at Whittier, Alaska \\ by \\ D.J. Nicolsky¹, G.J. Wolken², R.A. Combellick², and R.A. Hansen ${ }^{1}$}

\section{Introduction}

During summer 2011, scientists from the Alaska Division of Geological \& Geophysical Surveys (DGGS) conducted geologic-hazards fieldwork around Passage Canal and discovered a number of mass-movement features, including several rockfalls along the steep slopes of Passage Canal. A large subaerial rockfall entering into Passage Canal has the potential to generate a local tsunami that could impact the community of Whittier and damage critical infrastructure.

The destructive effects of mass-movement-generated tsunamis have been previously identified in south-central and southeastern Alaska. The best known and largest subaerial mass-movement-generated tsunami of historic time occurred in Lituya Bay, Alaska, on June 9, 1958, when a magnitude 7.9 earthquake occurred on the nearby Fairweather fault and produced an estimated 30 million $\mathrm{m}^{3}\left(1,050\right.$ million $\left.\mathrm{ft}^{3}\right)$ rockfall that rapidly entered the water and initiated a tsunami with the highest wave ever recorded (524 m/1,700 ft) (Miller, 1960).

In light of recent field observations indicating the potential for a large subaerial rockfall into Passage Canal, and to provide guidance to local emergency management agencies in tsunami hazard assessment, we append this brief report that considers an additional hypothetical rockfall-generated tsunami scenario in Passage Canal.

\section{Aerial and field observations}

A large bedrock fracture with a downhill-facing scarp was identified above the north shore of Passage Canal (figs. B-1 and B-2). The fracture is located above an active rockfall, characterized by intermittent toppling of rock

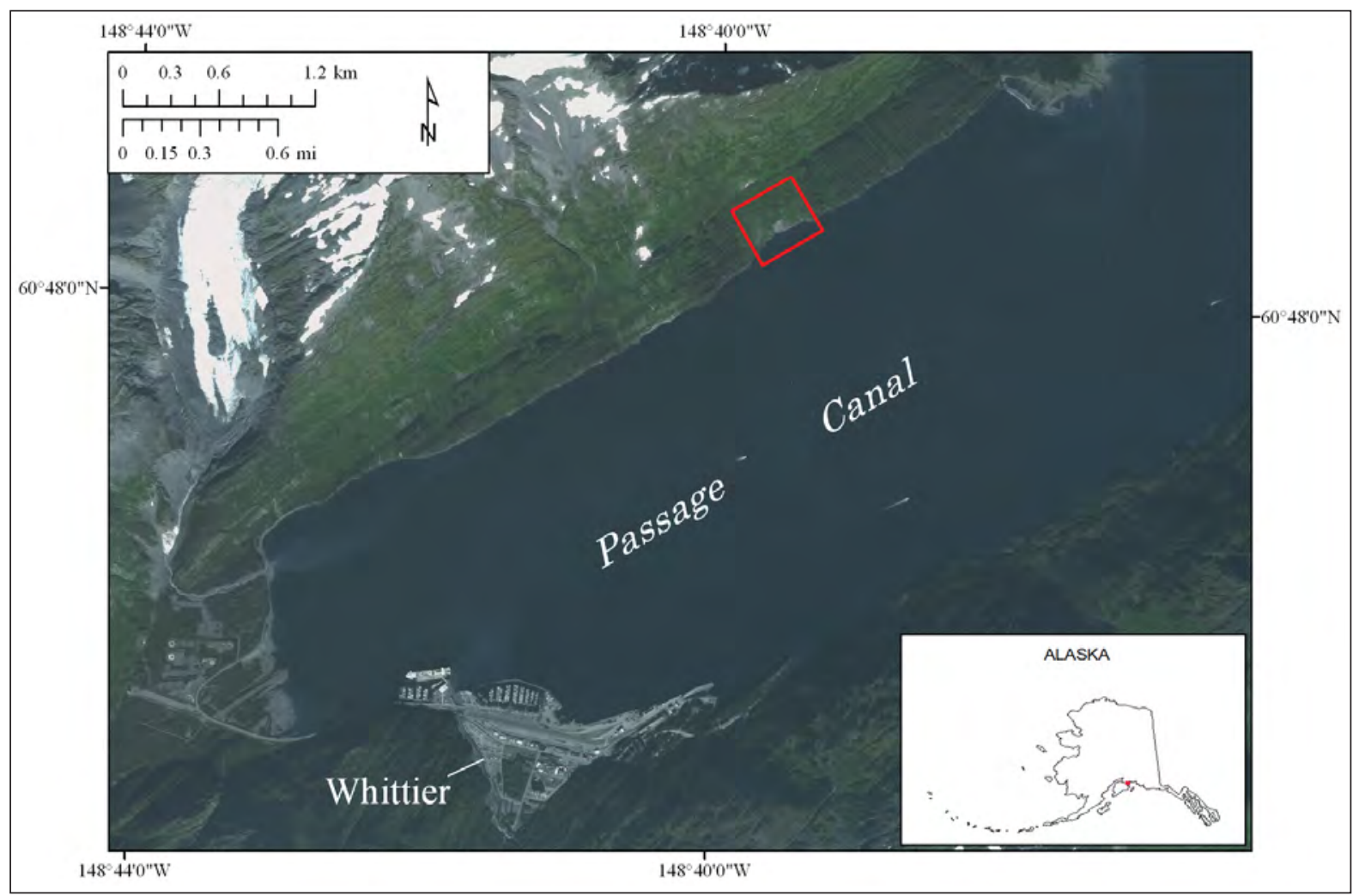

Figure B-1: 2010 SPOT satellite image of western Passage Canal and Whittier, Alaska. The red box indicates the location of the main rockfall and bedrock fracture.

${ }_{1}^{1}$ Alaska Earthquake Information Center, Geophysical Institute, University of Alaska, P.O. Box 757320, Fairbanks, Alaska 99775-7320

${ }^{2}$ Alaska Division of Geological \& Geophysical Surveys, 3354 College Rd., Fairbanks, Alaska 99709-3707 


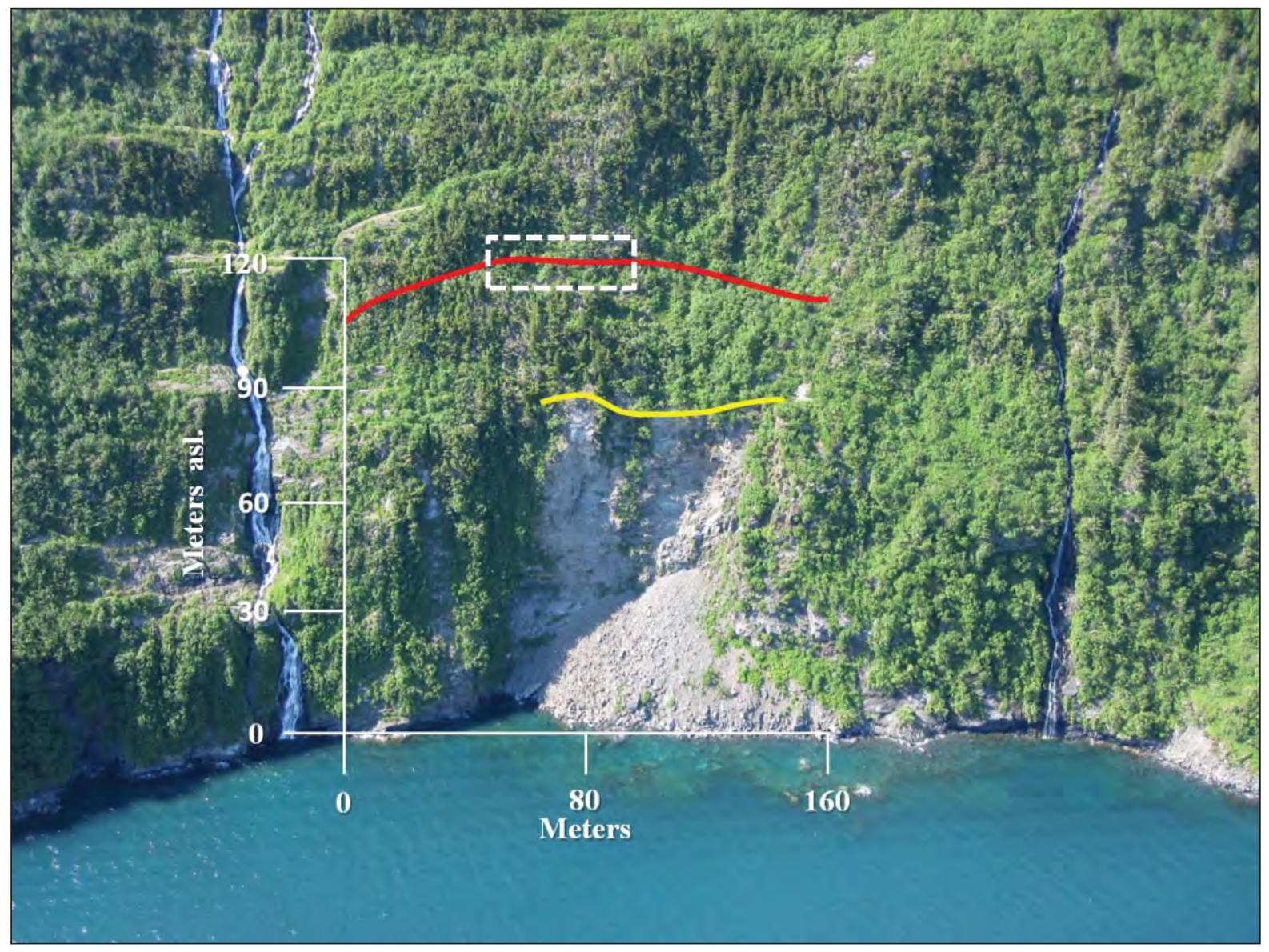

Figure B-2: Photograph of the main rockfall and fracture above the north shore of Passage Canal. The yellow line shows the active scarp of the rockfall, the red line shows the position of the bedrock fracture, and the dashed white box indicates the location of the photographs in figure B-4.

debris ranging from small fragments to boulders up to $3 \mathrm{~m}(10 \mathrm{ft})$ in diameter. The fracture exhibits relatively less weathering and oxidation compared to surrounding rocks and remains free of vegetation (fig. B-3), suggesting a relatively recent formation. Although no exact age is known, analysis of historic aerial photographs and satellite imagery indicates that the scarp occurred between 1950 and 1978.

The bedrock fracture is approximately $55 \mathrm{~m}(180 \mathrm{ft})$ above the active rockfall scarp, or approximately 120 $\mathrm{m}$ (400 ft) above sea level. It is mostly obscured by dense vegetation and is only visible from the air, mostly in areas of snow-avalanche scars. Views of the fracture from the air and ground are shown in figure B-3. Combined ground and aerial observations indicate that the fracture width ranges from 1.75 to $2.25 \mathrm{~m}(5.7-7.4 \mathrm{ft})$ and its length is about $160 \mathrm{~m}(520 \mathrm{ft})$. While the full length of the fracture remains unknown, the estimated surface area between the active rockfall scarp and observed fracture is near $6,200 \mathrm{~m}^{2}\left(67,000 \mathrm{ft}^{2}\right)$. The fracture has an arcuate convex-up form, suggesting that its origin could be related to the mechanisms influencing the active rockfall below. No other cracks are visible between the fracture and active rockfall scarp, indicating that the bedrock block below the fracture may have detached rigidly in response to the removal of lateral support from the mountain slope (glacier debuttressing), possibly in combination with external stimuli, such as seismic activity, rapid snowmelt, and intense rainfall.

We emphasize that the field observations of the depth of the fracture, and hence the total thickness of the material that can fail, are inconclusive. The fracture is located in a broad snow-avalanche zone where rock and vegetation are regularly transported down slope, resulting in avalanche debris lodged in the fracture. The debris forms an intermittent false "floor" at a $2 \mathrm{~m}$ (7 ft) depth, obscuring the true depth. On the basis of these surface measurements, it is estimated that a volume of the potential rockfall is considerably less than that of the 1958 Lituya Bay rockfall. 


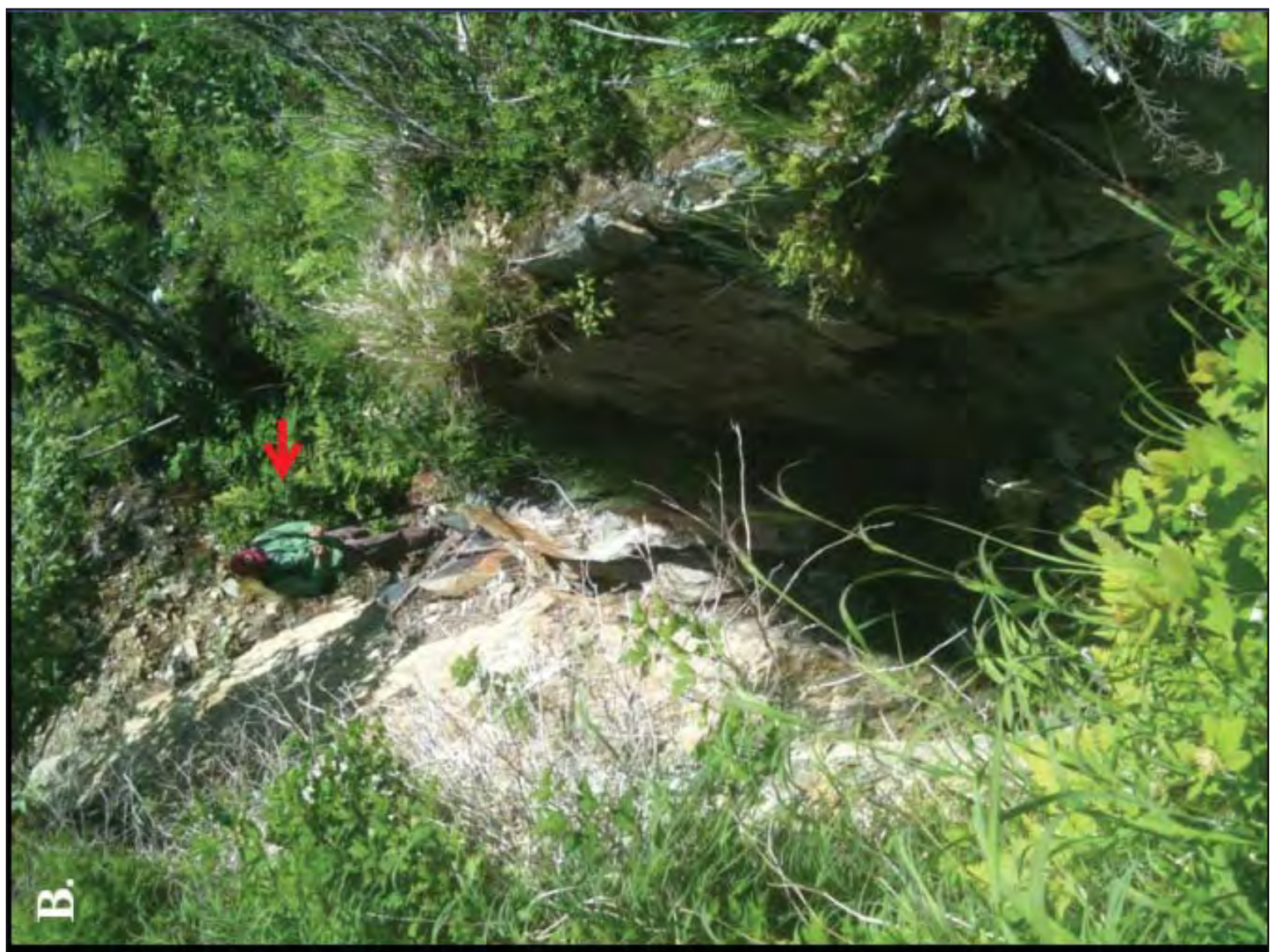

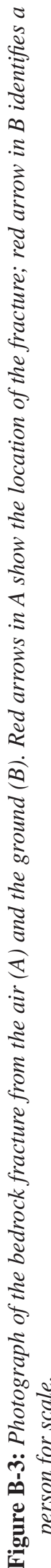




\section{Methodology and data}

Our ability to accurately model effects of a potential rapid subaerial mass failure into Passage Canal and the subsequent impact of the rockfall-generated tsunami on Whittier depends on our knowledge of the type and geometry of the mass movement and the local bedrock geology. Dense vegetation covers the slope on which the fracture is located; as a result, the total length and geometry of the fracture is currently unknown. Moreover, in the absence of drilling and seismic profiling, the volume of the detached ground material is undetermined. Thus, the rockfall-generated tsunami scenario presented below represents our best estimate based on the currently available information.

\section{Hypothetical rockfall tsunami source}

An aerial view of the rockfall is shown in figure B-4. The red line in this figure marks the hypothesized extent of the potential rockfall. Based on field observations, we assume that the upper limit of the potential rockfall is constrained by the bedrock fracture (figs. B-2 and B-3). The lateral extent of the potential rockfall was assumed based on extension of the arcuate form of the fracture. Note that the upper limit coincides with the surveyed extent of the fracture, the location of which is shown by a series of white triangles representing GPS measurements. The lower boundary of the rockfall is assumed here to be located well below the water surface. The green line dissects the area roughly in half and is used to illustrate hypothetical failure surfaces along the transect XY. Because the subsurface geologic data are missing, we calculated two hypothetical failure scenarios in order to give a range of variability in the modeled run-up.

In figure B-5, Cases A (red) and B (green) represent failure curves along the transect XY. The upper boundary of the rockfall is placed at the fracture, or $120 \mathrm{~m}(400 \mathrm{ft})$ above the water, while the lower boundary is assumed to be $60 \mathrm{~m}$ (200 ft) below the water surface. We estimate that in Case A the total volume of the hypothetical rockfall

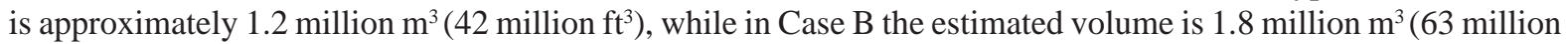
$\mathrm{ft}^{3}$ ). We emphasize that these volumes are rough estimates, and further research is necessary to refine these values.

\section{Numerical modeling}

Modeling of waves generated by a rapid failure of the fjord slope presents a major difficulty in the tsunamihazard assessment. An impact of the rockfall on the water surface results in a turbulent splash and consequent mixing of the granular flow with water. As the rockfall material submerges, a non-linear interaction of the sliding rockfall material with water further shapes the generated tsunami.

Typically, there are several regions with distinct tsunami features considered around the rockfall. In the splash zone, a turbulent and chaotic water behavior (Fritz, 2002) can be modeled up to a certain extent by the 3-D Navier-Stokes equations coupled with an appropriate model of the slide (Heinrich, 1992; Heinrich and others, 1998). The choice of slide model depends on the type of the ground material and its rheology. Beyond the splash zone, in the so-called near-field zone, chaotic waves evolve into a well defined wave that propagates away from the slide. Finally, the far-field zone is characterized by a steady partitioning of the kinematic and potential energy and by a well defined wave form.

Identifying these zones is a complicated task and involves both theoretical and experimental studies (Mei, 1983; Fritz, 2002; Walder and others, 2006). On other hand, if the splash zone is much smaller than the distance to a location where the run-up needs to be assessed, then it is common to assume that the splash zone is a 'black box' (Walder and others, 2006). The water wave is thought to be emerging from the 'black box' with well defined characteristics, that is, the wave exiting the splash zone is approximated by a soliton (Watts and Waythomas, 2003; Waythomas and others, 2006) or a parabola (Wieczorek and others, 2007). The initial wave height is parameterized by its slide volume, density, thickness, and velocity when the slide plunges into the water.

Instead of determining an initial wave profile (for example, the shape of the soliton), we assume that, to a certain extent, the rockfall can be approximated by a viscous slide that generates a tsunami. The dynamics of the sub-aerial part of the rockfall are modeled incorrectly, but the errors introduced are probably no greater than those introduced if the initial wave profile were specified as mentioned above. The simulated wave height 15 seconds after the failure, estimated for Case B, is shown in figure B-6. In a cross-section, the computed wave resembles a soliton and most of its energy is directed perpendicular to the shore. According to numerical modeling experiments, the rockfall is almost completely submerged 15 seconds after the failure and its further interaction with water is simulated by a viscous slide model coupled with the long-wave approximation for water waves. The model description ${ }^{3}$ is provided in Section "Numerical model of landslide-generated tsunami waves." We emphasize that along with the numerical modeling assumptions in the splash zone, geometry and configuration of the rockfall introduces most of the uncertainties in the presented modeling.

\footnotetext{
${ }^{3}$ The rockfall density is assumed to be $2,700 \mathrm{~kg} / \mathrm{m}^{3}\left(170 \mathrm{lb} / \mathrm{ft}^{3}\right)$.
} 
The potential tsunami can reach Whittier in approximately one and one-half minute after the failure. The wave height in Passage Canal at Point 17, which is just outside of the Whittier harbor, is estimated to be about $2 \mathrm{~m}$ (7 ft). Most of the inundation is localized in the eastern part of the city near the small harbor. However, according to numerical experiments, the wave breakers are over-topped and a limited inundation within the harbor parking area is also expected. The modeled extents of the inundation in Rockfalls A and B are shown in figure B-7, by red and green lines, respectively. The sea level dynamics and water velocities at the inundated locations are plotted in figure B-8. The maximum wave height is approximately $3 \mathrm{~m} \mathrm{(10} \mathrm{ft)} \mathrm{at} \mathrm{Point} \mathrm{5.} \mathrm{The} \mathrm{waves} \mathrm{can} \mathrm{reach} 1.5 \mathrm{~m}(5 \mathrm{ft})$ in the Whittier harbor, but subside after several erratic oscillations.

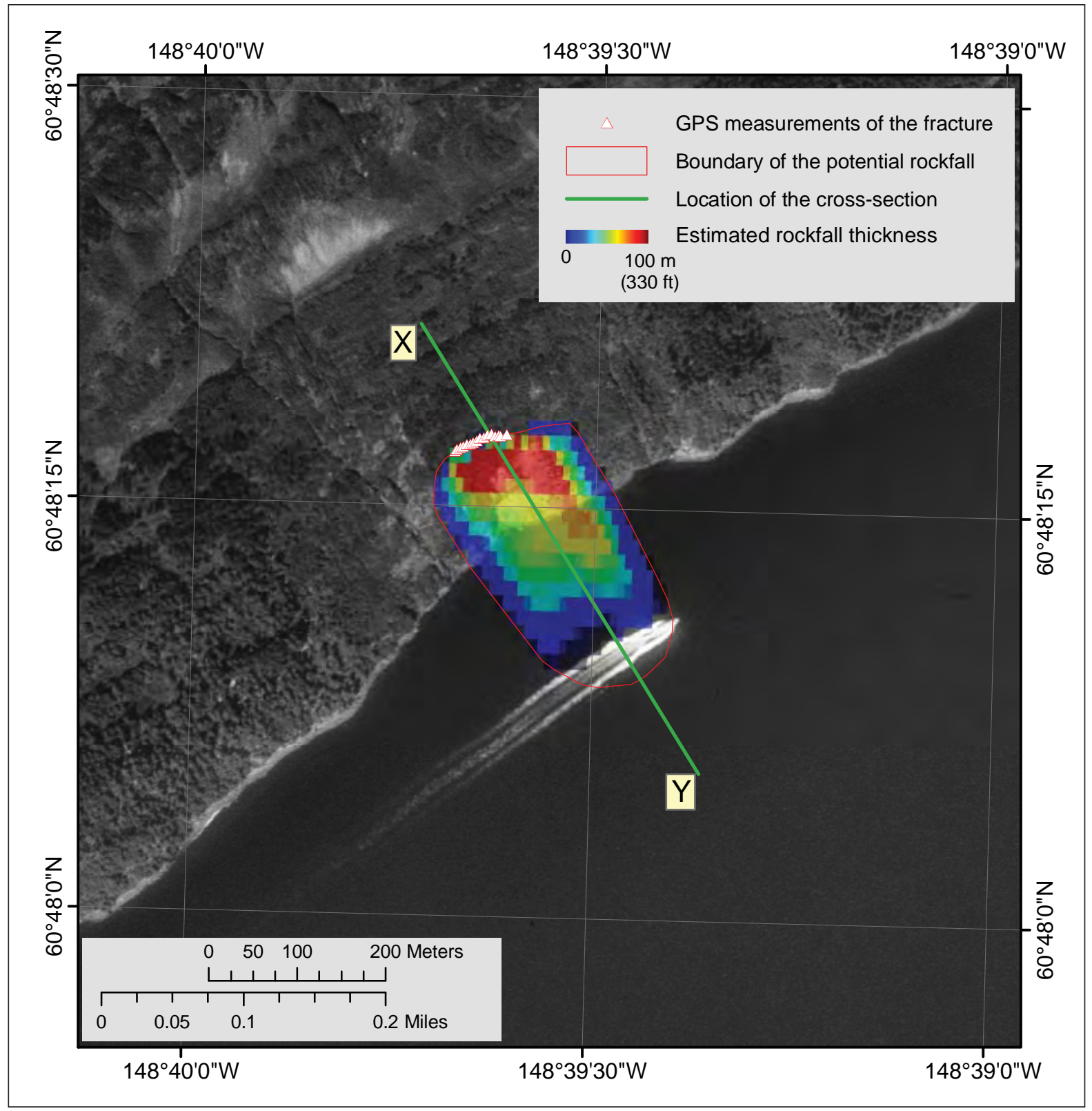

Figure B-4: Aerial view of the study area with the red line showing an extent of the potential rockfall. GPS locations of a visible part of the fracture are marked by white triangles. The green line shows a transect, along which two cases of the hypothetical failure surfaces are proposed (see figure B-5). The thickness of the rockfall, estimated for Case B, is shown on top of the image. The maximum thickness is approximately $70 \mathrm{~m}$ (230 ft) near the fracture. 


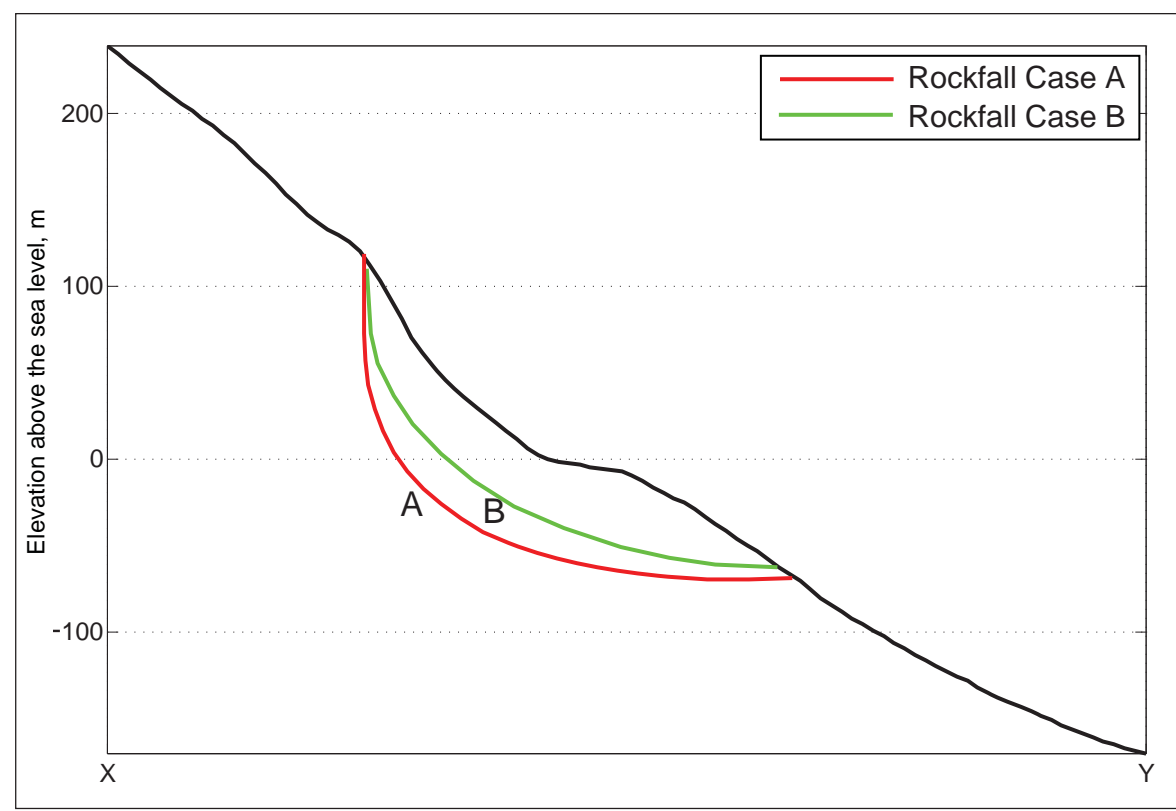

Figure B-5: Failure surfaces along the transect XY plotted by a green line in figure B-4.

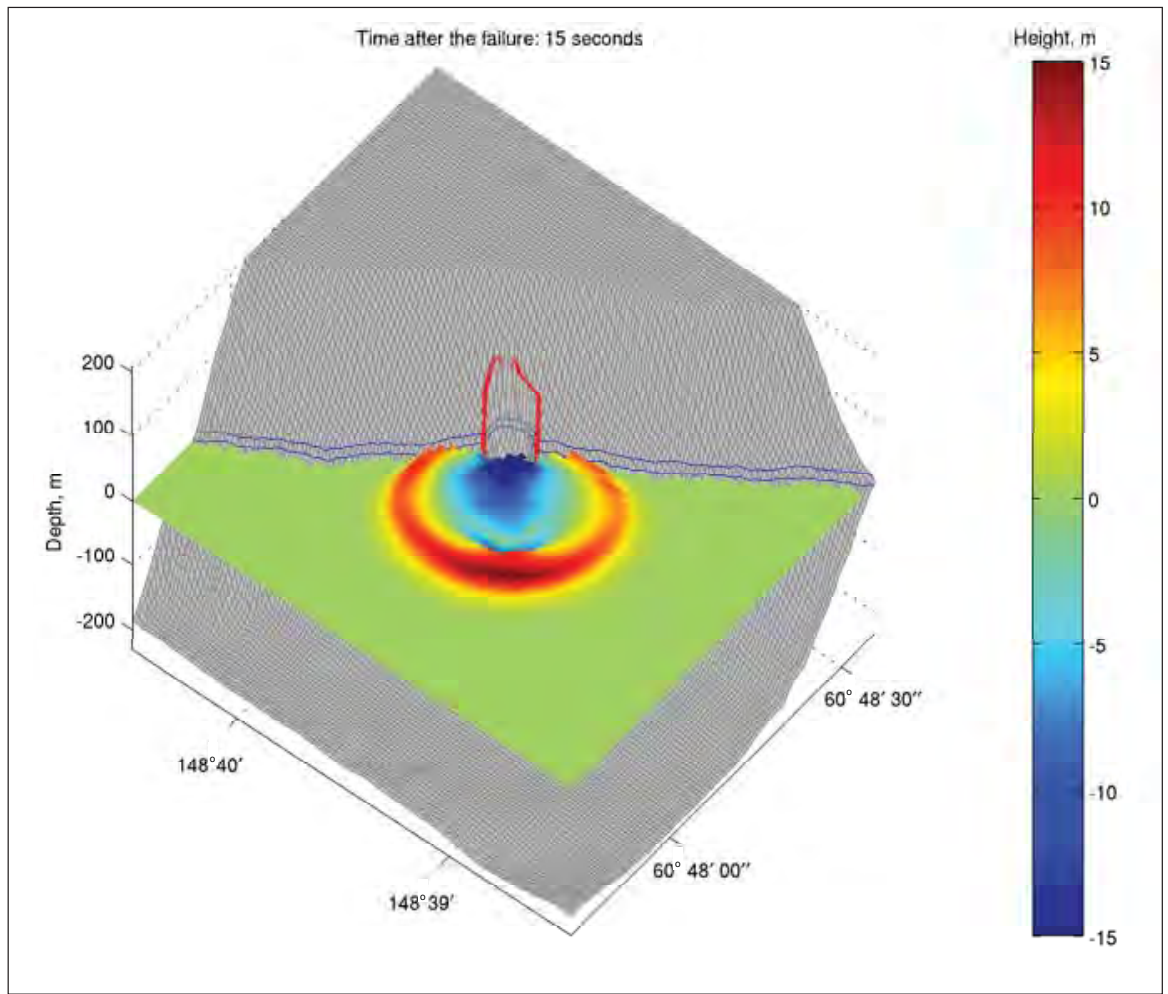

Figure B-6: Numerically modeled wave leaving the splash zone 15 seconds after the rockfall failure. The extent of the rockfall is marked by a red line. The blue lines correspond to 0 and $10 \mathrm{~m}$ (33 ft) elevations above the sea level. The DEM corresponds to the present-day MHHW datum. For the sake of visualization, the elevations are cut at the $200 \mathrm{~m}(660 \mathrm{ft})$ level. 


\section{Sources of errors and uncertainties}

The hydrodynamic model used to calculate tsunami propagation and run-up is a nonlinear, flux-formulated, shallow water model (Nicolsky and others, 2011). It passed the validation and verification tests required for models used in production of tsunami inundation maps (Synolakis and others, 2007). In a series of papers, several numerical methods, based on Boussinesq-type approximation, were developed (Madsen and others 1991; Kirby and others 1998). However, the advantage of the latter models over classical shallow-water equations in matching field observations is an active area of research (Lynett and others, 2003; Tappin and others 2008).

Volume and configuration of the potential slope failure, dynamics of the rockfall, as well as the rheological properties of the sliding material are the largest uncertainties in the presented tsunami modeling study. Thus, additional in situ measurements and future modeling efforts are required to address these uncertainties.

\section{References Cited}

Fritz, H.M., 2002, Initial phase of landslide generated impulse waves: Zürich, Switzerland, Swiss Federal Institute of Technology (ETH), Ph.D. dissertation.

Heinrich, Philippe, 1992, Nonlinear water waves generated by submarine and aerial landslides: Journal of Waterway, Port, Coastal, and Ocean Engineering, v. 118, p. 249-266.

Heinrich, Philippe, Mangeney, Anne, Guibourg, Sandrine, Rocher, Roger, Boudon, Georges, and Cheminee, JeanLouis, 1998, Simulation of water waves generated by a potential debris avalanche in Montserrat, Lesser Antilles: Geophysical Research Letters, v. 25, no. 19, p. 3,697-3,700.

Kirby, J.T., Wei, G., Chen, Q., Kennedy, A.B., and Dalrymple, R.A., 1998, FUNWAVE 1.0, Fully nonlinear Boussinesq wave model; Documentation and user’s manual: Report CACR-98-06, Center for Applied Coastal Research, Department of Civil and Environmental Engineering, University of Delaware.

Lynett, P.J., Borrero, J.C., Liu, P.L.F., and Synolakis, C.E., 2003, Field survey and numerical simulations-A review of the 1998 Papua New Guinea tsunami, in Bardet, Jean-Pierre, Synolakis, C.E., Davies, H.L., Imamura, Fumihiko, and Okal, E.A., eds., Landslide tsunamis; Recent findings and research directions: Basel, Switzerland, Birkhaeuser, Pure and Applied Geophysics, v. 160, no. 10-11, p. 2,119-2,146.

Madsen, P.A., Murray, Russel, and Sorensen, O.R., 1991. A new form of the boussinesq equations with improved linear dispersion characteristics: Coastal Engineering, v. 15, no. 4, p. 371-388.

Mei, C.C., 1983, The Applied Dynamics of Ocean Surface Waves: John Wiley \& Sons, 760 p.

Miller, D.J., 1960, Giant Waves in Lituya Bay, Alaska: U.S. Geological Survey Professional Paper 354-C, p. 51-86, 1 sheet, scale 1:50,000.

Nicolsky, D.J., Suleimani, E.N., and Hansen, R.A., 2011, Validation and verification of a numerical model for tsunami propagation and runup: Pure and Applied Geophysics, v. 168, p. 1,199-1,222, http://dx.doi. org/10.1007/s00024-010-0231-9.

Synolakis, C.E., Bernard, E.N., Titov, V.V., Kânoğlu, U., and González, F.I., 2007, Standards, criteria, and procedures for NOAA evaluation of tsunami numerical models: Seattle, Washington, NOAA/Pacific Marine Environmental Laboratory, Technical Memorandum OAR PMEL-135, 55 p.

Tappin, D.R., Watts, Philip, and Grilli, S.T., 2008, The Papua New Guinea tsunami of 17 July 1998-Anatomy of a catastrophic event: Natural Hazards and Earth System Sciences, v. 8, no. 2, p. 243-266.

Walder, J.S., Watts, P., and Waythomas, C.F., 2006, Case study: Mapping tsunami hazards associated with debris flow into a reservoir: Journal of Hydraulic Engineering, v. 132, no. 1, p 1-11.

Watts, P., and Waythomas, C.F., 2003, Theoretical analysis of tsunami generation by pyroclastic flows: Journal of Geophysical Research, B, Solid Earth and Planets, v. 108, p. 21.

Waythomas, C.F., Watts, P., and Walder, J.S., 2006, Numerical simulation of tsunami generation by cold volcanic mass flows at Augustine Volcano, Alaska. Natural Hazards and Earth System Science, v. 6, no. 5, p. 671-685.

Wieczorek, G.F., Geist, E.L., Motyka, R.J., and Jakob, M., 2007, Hazard assessment of the Tidal Inlet landslide and potential subsequent tsunami, Glacier Bay National Park, Alaska: Landslides, v. 4, p. 205-215. 


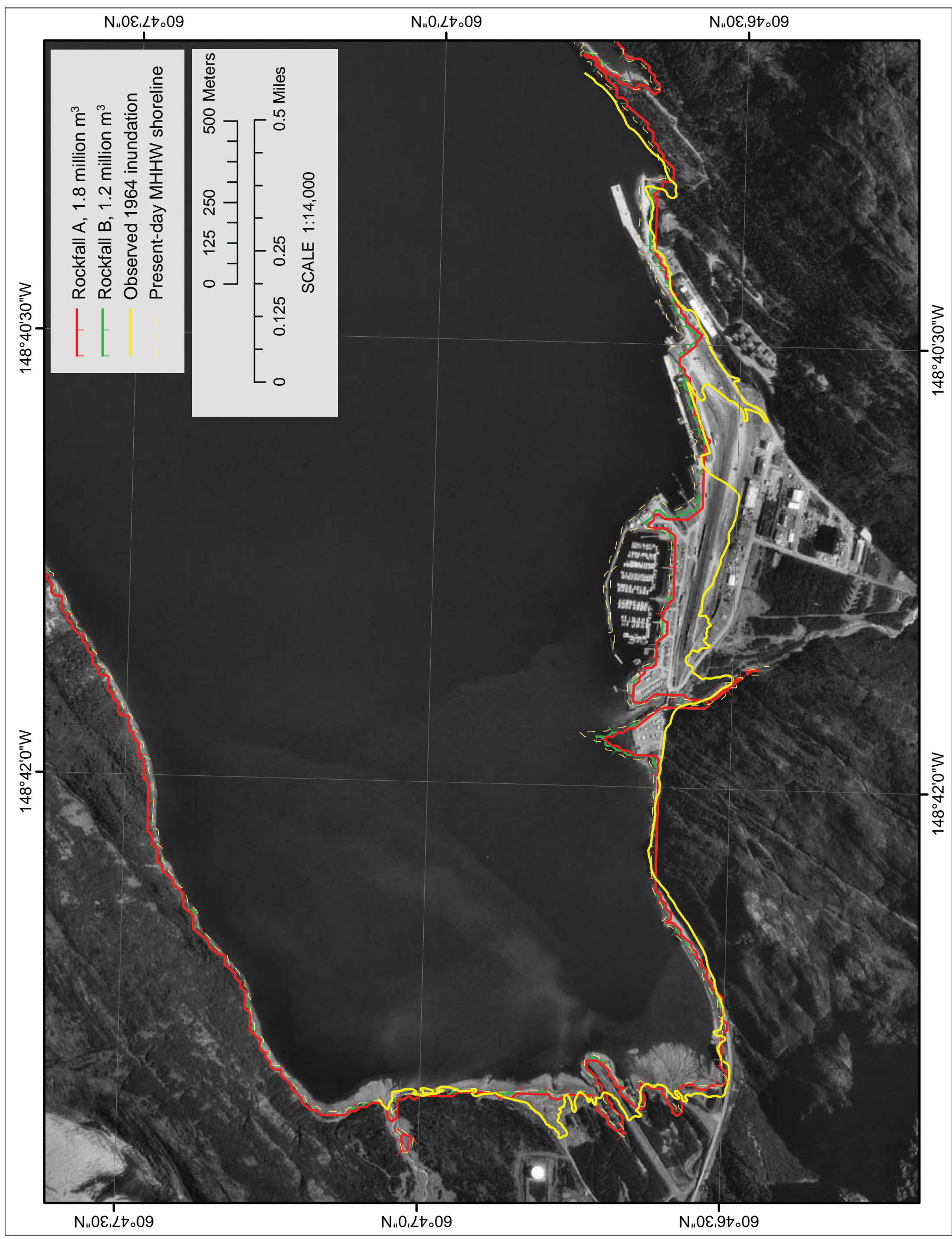

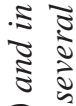

₹ के

:

ชิ ฮิ

?

ป.

हี

$\infty$ ह

ते ठ

$3 \quad \varangle$

$\llbracket 2$

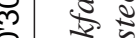

ะั

$\Xi \overleftarrow{0}$

ะ

吾

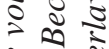

हี ह่ วิ

ये 용 ठे

ชे है

ठㄹ ह

苋旅

纹

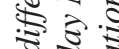

논

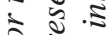

둥ㅎㅇ

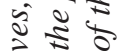

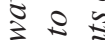

ช

$\approx \delta$

$\div$ 는

ปิ

के

ซㄴ

옹 몽

\&

₹ह

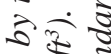

โ 5

$\because$.

हี

ฐ ฐ

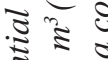

ธิ ธิ

ธํ. 오

ธ

\&

จำ

0.2

$\therefore$ D

뜰

ด

ป

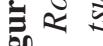

江 


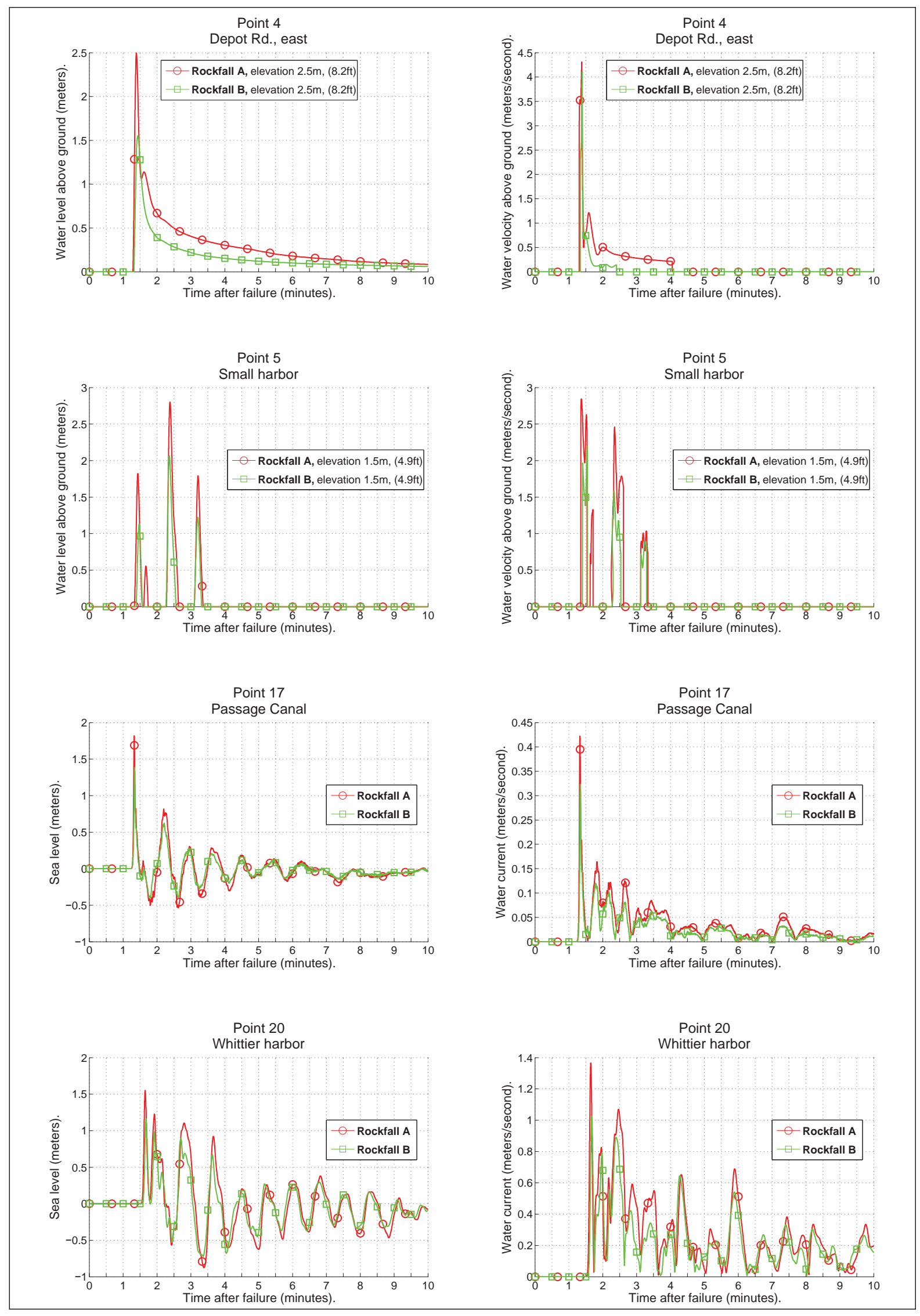

Figure B-8: Time series of the water level and velocity at the selected points in Rockfalls A and B. Location of the points are shown in figure A-1. 